National Uranium Resource Evaluation

\title{
SOME CONCEPTS OF FAVORABILITY FOR WORLD-CLASS-TYPE URANIUM DEPOSITS IN THE NORTHEASTERN UNITED STATES
}

By: Hans H. Adler

\section{Consulting Geologist}

Silver Spring, Maryland

March 1981

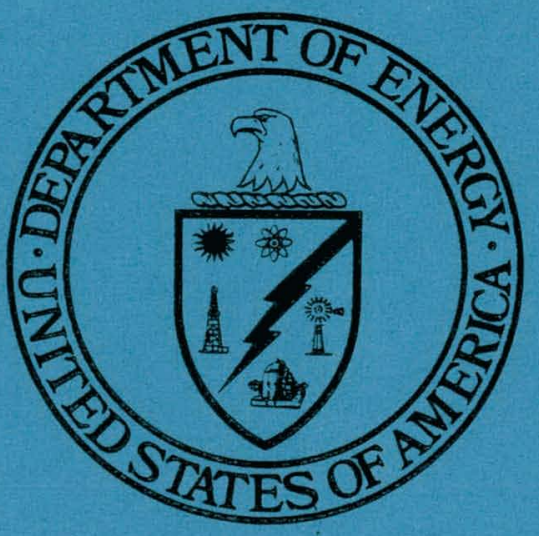

PREPARED FOR THE U.S. DEPARTMENT OF ENERGY Grand Junction Office, Colorado 


\section{DISCLAIMER}

This report was prepared as an account of work sponsored by an agency of the United States Government. Neither the United States Government nor any agency Thereof, nor any of their employees, makes any warranty, express or implied, or assumes any legal liability or responsibility for the accuracy, completeness, or usefulness of any information, apparatus, product, or process disclosed, or represents that its use would not infringe privately owned rights. Reference herein to any specific commercial product, process, or service by trade name, trademark, manufacturer, or otherwise does not necessarily constitute or imply its endorsement, recommendation, or favoring by the United States Government or any agency thereof. The views and opinions of authors expressed herein do not necessarily state or reflect those of the United States Government or any agency thereof. 


\section{DISCLAIMER}

Portions of this document may be illegible in electronic image products. Images are produced from the best available original document. 
Neither the United States Government nor any agency thereof, nor any of their employees, makes any warranty, express or implied, or assumes any legal liability or responsibility for the accuracy, completeness, or usefulness of any information, apparatus, product, or process disclosed in this report, or represents that its use would not infringe privately owned rights. Reference therein to any specific commercial product, process, or service by trade name, trademark, manufacturer, or otherwise, does not necessarily constitute or imply its endorsement, recommendation, or favoring by the United States Government or any agency thereof. The views and opinions of authors expressed herein do not necessarily state or reflect those of the United States Government or any agency thereof. 


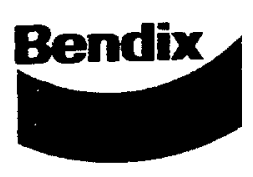

\section{Field Engineering Corporation}

Grand Junction Operations

$$
\text { . July 15, } 1981
$$

P. O. Box 1569

Grand Junction, CO 81502 Tel (303) 242-8621

A Subsidiary of The Bendix Corporation

To: A11 holders of GJBX-80(81.), "Some Concepts of Favorability for World-Class-Type Uranium Deposits in the Northeastern United States," by Hans $\mathrm{H}$. Adler

Please add the following missing 1 ine to page 108 at the end of the last paragraph:

possibly lacustrine, terrane rich in carbonaceous material. Because volcanics are

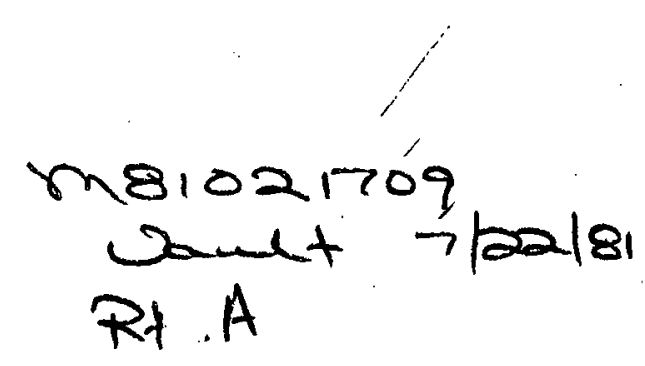




SOME CONCEPTS OF FAVORABILITY
FOR WORID-CLASS-TYPE
URANIUM DEPOSITS

IN THE. NORTHEASTERN UNITED STATES

by

H A NS H. ADLER

March 1981

SURMITED TO: U. S. DEPARTMENT OF ENERGY GRANT .JINCTINN, COLORADO

SUBMITTED BY: HANS H. ADIFR 13010 Daley Street Silver Spring, Maryland 20906

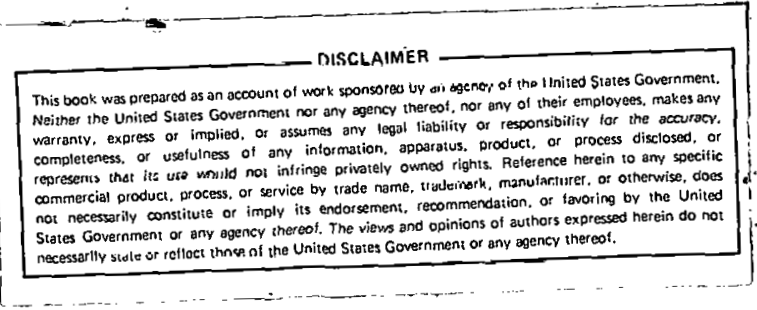


INTRODUCTION..................................... 1

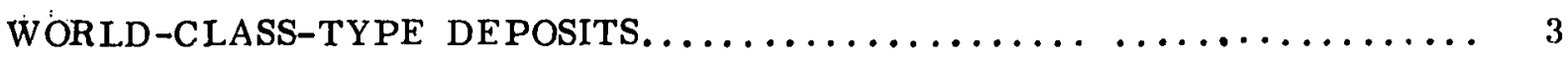

AREA OF INVESTIGATION. $\ldots \ldots \ldots \ldots \ldots \ldots \ldots \ldots \ldots \ldots \ldots \ldots \ldots \ldots \ldots \ldots$

NEW ENGLAND AND ADIRONDACK PRECAMBRIAN. ............. 6

STRATIFIED PHANEROZOIC ROCKS OF NEW ENGLAND............ 14

PHANEROZOIC PLUTONIC ROCKS OF NEW ENGLAND.............. 19

URANIUM IN GRENVILLE-DATED ROCKS OF THE NORTHEASTERN

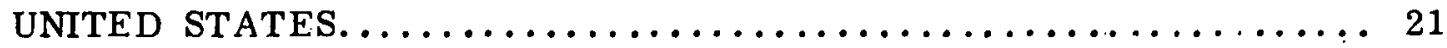

CANADIAN GRENVILIE PROVINCE...................... 22

GRENVILIE PROVINCE URANIFEROUS PEGMATITES, BANCROFT

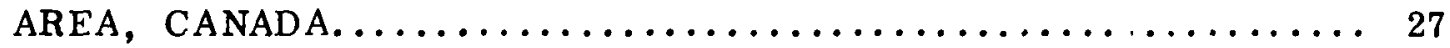

OTHER GRENVILLE PROVINCE URANIUM DEPOSITS............. 32

Baie Johan Beetz............................ 33

Romaine..................................... 35

St. Augustin River........................... 35

GRE NVILLE PROVINCE -- IN QUEST OF A "ROSSING" DE POSIT. . . . . . . 35

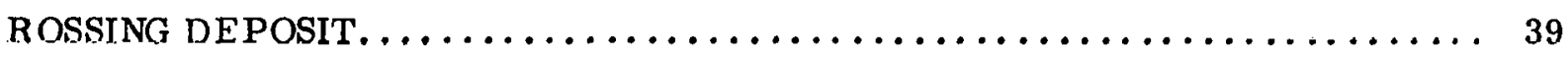

URANIUM DEPOSITS IN APHEBIAN METASEDIMENTS, LABRADOR...... 45

Kitts Deposit.............................. 47

Michelin Deposit............................. 48

Cape Makkovik-Monkey Hill Belt Deposits................. 50

Genetic Aspects................................ 51

PENA BLANCA URANIUM DEPOSITS, CHIHUAHUA, MEXICO......... 52 
ADIRONDACK MOUNTAINS REGION. ....................... 56

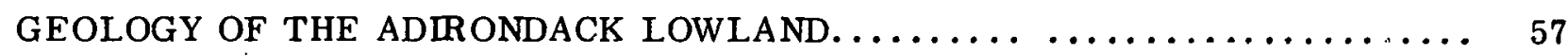

DEPOSITIONAL ENVIRONMENT OF THE GRENVILLE GROUP,

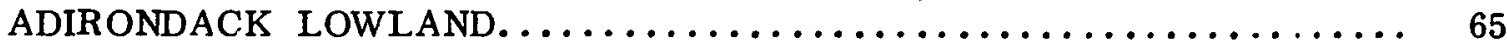

ADIRONDACK METAMORPHIC ROCKS AND RELATED URANIUM

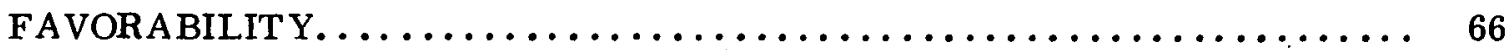

Reconstituted Paragneiss as a Possible Uranium Host Rock......... 66

Amphibolite and Metagabbro as Possible Uranium Host Rocks....... 69

Adirondack Pegmatites............................ 72

Alaskite................................... 72

Conceptual Uranium Favorability of Alaskite and Associated Rocks.... 75

URANIUM IN BLACK SHALES OF SWEDEN AND NORWAY ............ 80

Introduction. ............................... 8

Geologic Setting of Uraniferous Alum Shales--Platform Environment... 83

Uraniferous Cambro-Ordovician Sediments of the Caledonides--

Transitional Gcosynclinal Environment ................ 86

Proposed Origin of Uranium in Alum Shale................. 90

EFFECTS OF METAMOR PHISM ON BLACK SHALE............... 105

EUXINIC SHALE FACIES OF THF APPALACHIAN FOLD BELT.......... 108

AVALONIAN BLACK SHALES. ........................... 130

EFFECTS OF GRANITIZATION AND INTRUSION IN THE APPALACHIAN

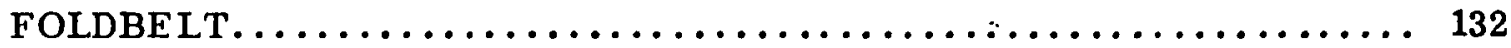

ACKNOWLEDGEMENTS. . ............................. 134

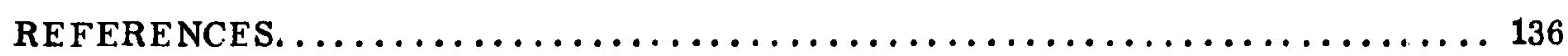

APPENDIX--WORLD-CLASS-TYPE DEPOSITS. .................. 144 


\section{LIST OF ILLUSTRATIONS}

Page

Figure 1. Structural divisions of North America (after Stearn,

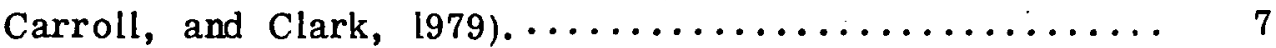

Figure 2. Geologic provinces of the eastern United States........... 8

Figure 3. New England province and Adirondack Uplift............. 9

Figure 4. Upper Proterozoic rocks of the Adirondack Uplift and New England province (after Zen, White, and

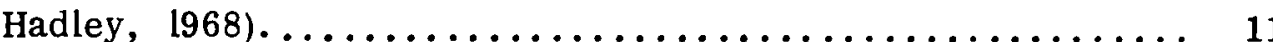

Figure 5. Avalonian rocks of nor theastern North America............ 12

Figure 6. Structural provinces of North America (atter Stockwell, 1968, and Stearn, Carroll, and Clark, 1979).......... 13

Figure 7. Tectonic features of northeastern United States. Anticlinoria and synclinoria define distribution of Paleozoic geosynclinal

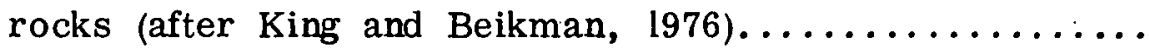

Figure 8. Generalized distribution of Paleozoic stratified rocks in the New England province (after Zen, White, and Hadley,

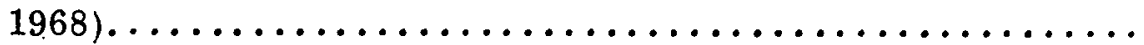

Figure 9. Uranium districts of the Grenville province, Canada....... 26

Figure 10. Kaipokok Bay-Big River uranium area setting, Labrador (after Gandhi, 1978)...................... 4

Figure 11. Pyritic schist layer in marble at Sylvia Lake, Adirondack

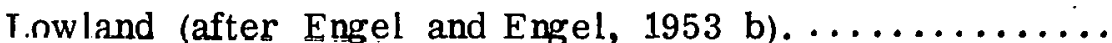

Figure 12. Geology of the Balmat-Edwards-Gouverneur region, Adirondack Lowland (after Engel and Engel, 1953 b, and Geological

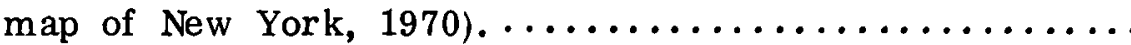

Figure 13. Alaskite bodies of the Adirondack Lowland (after Engel and Engel, 1953 b, and Geological map of New York, 1970)...

Figure 14. Distribution of alum shales in Sweden and Norway (after Armands, 1972, and OECD/IAEA, 1980)............

Figure 15. Diagramatic presentation of lithofacies variation from platform to geosyncline at the Tasjo hinge zone, Caledonides

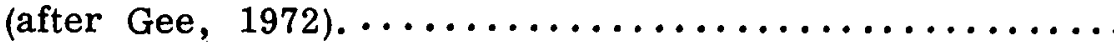


Figure 16. Distribution of $\mathrm{Cu}-\mathrm{Pb}-\mathrm{Zn}$ ores of the Caledonides (after Frietsch, Papunen, and Vokes, 1979).............. 93

Figure 17. Orogenic and depositional model--platform to eugeosyncline..... 104

Figure 18. Giddings Brook Slice (after Rowley, Kidd, and Delano; 1979)..... 114

Figure 19. Index map of various black shale localities in the New England and adjacent regions....................... 118 


\section{SOME: CONCEPTS OF FAVORABILITY \\ FOR WORLD-CLASS-TYPE \\ URA NIUM DEPOSITS}

IN THE NORTHEASTERN UNITED STATES

\section{INTRODUCTION}

This report is an account of concepts of favorability of geologic environments in the eastern United States for uranium deposits of several major types existing elsewhere in the world; i.e. world-class-type deposits. Its purpose is to convey some initial ideas about the interrelationship of the geology of the eastern United States and the geologic settings of certain of these world-class deposits.

The study and report include consideration of uranium deposits other than those generally manifesting the geologic, geochemical and genetic characteristics associated with the conventional sandstone-type ores of the western United States. This is in keeping with the usage of the term "world-class" in conjunction with the National Uranium Resource Evaluation Program of the U. S. Department of Energy to denote. deposits that are important sources of uranium outside of the United States but have not yet been recognized within the United States. It should be noted, however, that sandistone-type deposits are an important source of uranium elsewhere in the world.

The focus of this study is on the eastern part of the United States. In contrast with the western half, the eastern section appears conspicuously lacking in uranium occurrences having apparent potential for major economic resources of that metal, with the possible exception of byproduct production from phosphate mining operations and conceivable recovery from low-grade Devonian shales. This difference in favorability can be related primarily to significant differences in geologic factors and climate that govern and affect the initial distribution and reworking of uranium in sandstone. 
The favorable western regions contain large resources of uranium in sandstones in areas that have been subjected to considerable acid volcanic activity within the past 150 million years. The coincidence of acid volcanism and uranium mineralization has given rise to the popular belief among many geologists that the volcanic sediments and related debris, which are still much in evidence, were the source of the uranium now found and being mined in the pyritiferous and/or carbonaceous Triassic, Jurassic, and early Cenozoic sandstones containing the bulk of domestic uranium resources. There are no comparable areas of volcanism in the eastern Unitod Statcs within the same time frame, and sandstones of similar age are only sparsely existent.

Although a "scenario" for uranium favorability comparable to the western United States is generally lacking in the east, volcanism may nevertheless be the most useful key to uranium favorability here. Favorability clues tied to volcanism exist in the uranium settings of eastern Canada. They also exist, conceptually at least, in the analogies that can be drawn between the uranium-favorable geology of Africa and western Europe and the eastern United States. The comparisons are applicable to sedimentary, metamorphic, and igneous rocks that fall within the time span from early Proterozoic to late Paleozoic and early Mesozoic. They include rocks involved in the formation of the Canadian Shield, and its projections in the United States, the Appalachian eugeosyncline and mountain systems, and the Caledonian, Hercynian and younger or ogenic belts.

For the most part, the platform sediments lying to the weat of the Appalachian Mountains were not considered in this project because of their general lack of environments conducive to world-class deposit types.

It should be made clear at the outset that it was not the purpose of this study to point to specific local areas as favorable or unfavorable for uranium, as this would 
have entailed a preparatory effort far greater than could realistically have been made in the time alloted to the project. Local areas containing conceptually favorable environments have, nevertheless, been mentioned whenever possible. In keeping with 1 express project goals, the main study objective was to examine various world-class geologic settings, draw inferences therefrom, explore various geologic analogies, and develop from this some cohesive concepts that may aid in directing the DOE's National Uranium Resource Evaluation Program efforts toward geologic settings that presumably warrant attention.

\section{WORLD-CLASS-TYPE DEPOSITS}

The major uranium resources of the world have been assigned by the Joint Steering Group on Uranium Resources of the OECD Nuclear Energy Agency and the International. Atomic Energy Agency to six categories of deposit types on the basis of geologic setting (OECD/IAEA, 1980) as follows:

1. Quartz-pebble conglomerate deposits

2. Proterozoic unconformity-related deposits

3. Disseminated magmatic, pegmatitic, and contact deposits in igneous and metamorphlc rocks

4. Vein deposits

5. Sandstone deposits

6. Other types of deposits

Several of these categories can be further subdivided into more precisely defined deposit types on the "basis of geologic characteristics, habit and mode of formation. Although a review of the classifications developed by various investigators is not essential to this report, a list condensed from a number of published papers is 
nevertheless appended for reference as it illustrates the variety of geologic settings in which uranium has been found and which might be included for consideration in a study of this type. (Appendix 1).

It is questionable whether some world-class-type deposits, containing very large uranium resources and therefore meriting particular attention, should be ruled out at the outset as having any likelihood of occurring in the eastern United States. At least in their original form and under conditions of their normal settings in Canada and South Africa, quartz-pebble conglomerate deposits are highly unlikely to be found here. ' This also applies to Proterozoic unconformity-related deposits as exemplified by their north Australian and Canadian settings. Both occur in Aphebian rocks $(2,400-1,650$ m.y.; Precambrian X) which, although conceivably existent on the basis of Canadian studies, are not geochronologically identified in the Precambrian of the eastern United States (King, 1976). Uraniferous conglomerates may exist or have existed in this region only if the Grenvillian rocks (i.e. dated by the Grenville orogeny) within the Adirondack uplift of New York, or the outlying massifs to the east and southeast, comprise at least in part tectonically overprinted Aphebian rocks, a condition that is not beyond credibility. However, the existence of conglomerate deposits also requires that original host rocks, i.e. fluvial or marginal marine conglomerates, have been deposited prior to the evolution of oxygen in the atmosphere. Whether such assumptions are permissible is a moot question that cannot be resolved here.

Questionable, too, is the existence of Proterozolc unconformity-related deposits. Kalliokoski, Langford, and Ojakangas (1978) examined the relationships between Grenville basement and permeable cover, providing access by uraniferous waters, and concluded that the opportunities for finding such deposits were very marginal even under conditions of their expanded model which considerably enlarged the range of favorable 
environments. Genetic concepts are, in the opinion of the writer, still inadequate to account for the formation of this class of deposits, and until a better geochemical model is developed a completely open mind to all possibilities would seem to be the best course.

Because this report makes frequent reference to Canadian geology, it should be noted for comparison that Precambrian units $W, X, Y$, and $Z$ on the geologic map of the United States correspond broadly with the Archean ( 2,400 m.y.), Aphebian (2,4001,650 m.y.), Helikian (1,650 - 900 m.y.) and Hadrynian (900 - 600 m.y.) of Canada:

\section{AREA OF INVESTIGATION}

For uranlum assessment purposes, the eastern United States is divided into two resource regions: the Appalachian Highlands and the Coastal Plain (U. S. Department of Energy, 1980). Only the Appalachian Highlands area contains a sufficiently diverse geology to embody a variety of world-class-type uranium deposits. Its western part, the Appalachian Plateau or Appalachian Basin, is underlain by nearly flat-lying Paleozoic sediments and beyond its easternmost reaches is generally not of interest here. The eastern part of the Appalachian Highlands includes the Adirondack dome and the Appalachian Mountains which contain a varied sedimentary, metamorphic, and igneous terrain ranging from Precambirian to Cenozoic.

The Appalachian Mountains stretch from Alabama to Maine and project northward into New Brunswick and Newfoundland (Figure 1). Their geology is coextensive with that of the Canadian provinces. The Appalachian Mountain system is divisible into $a^{*}$ southern and central section, containing the Piedmont, Blue Ridge, and Valley and Ridge provinces, and a northern New England-Maritime section (Figure 2). The three divisions of the southern and central Appalachians are difficult to recognize nor th 
of the Hudson River Valley which serves as an appropriate approximate line of demarcation for purposes of this investigation. The southern and central Appalachian Mountains are not included in this study because correlation of the geology of the region with that of Canada and western Europe is more difficult than for the northern Appalachians, and extrapolation of uranium favorability based on such correlations is therefore more tenuous. This investigation is, accordingly, restricted essentially to the New England Province of the Appalachians and the Adirondack Uplift (Figure 3).

\section{NEW ENGLAND AND ADIRONDACK PRECAMBRIAN}

The Canadian Shield (Figure 1) constitutes the largest area of exposed Precambrian rocks in North America. Shield rocks extend under the younger platform sediments of the craton from. Canada into the United States. In the investigation area, southward projections of the shield form the Adirondack Mountains and the small inliers protruding through Phanerozoic sediments and mctasediments in the New England Province where they make up the Hudson, Housatonic, Berkshire, and Green Mountain massifs (Figure 4). These rocks are dated by the Grenvillian orugeny.

Precambrian rocks of Rhode Island and southeastern Massachusetts are unrelated to Grenvillian rocks of the. Adirondacks. These rocks are dated as Hadrynian (Precambrian Z on the Geologic Map of the United States) and form the southward extension of the Avalonian belt of southern New Brunswick, southeastern Newfoundland, and , Cape Breton Ialand (Figure 5). Avalonian sediments are believed to have been welded to the North American continent during late-Paleozoic closure of the proto-Atlantic ocean (Iapetus) and are presumably either of African derivation or constitute the remnants of island-arc chains that existed far from both North American and African cratons. 


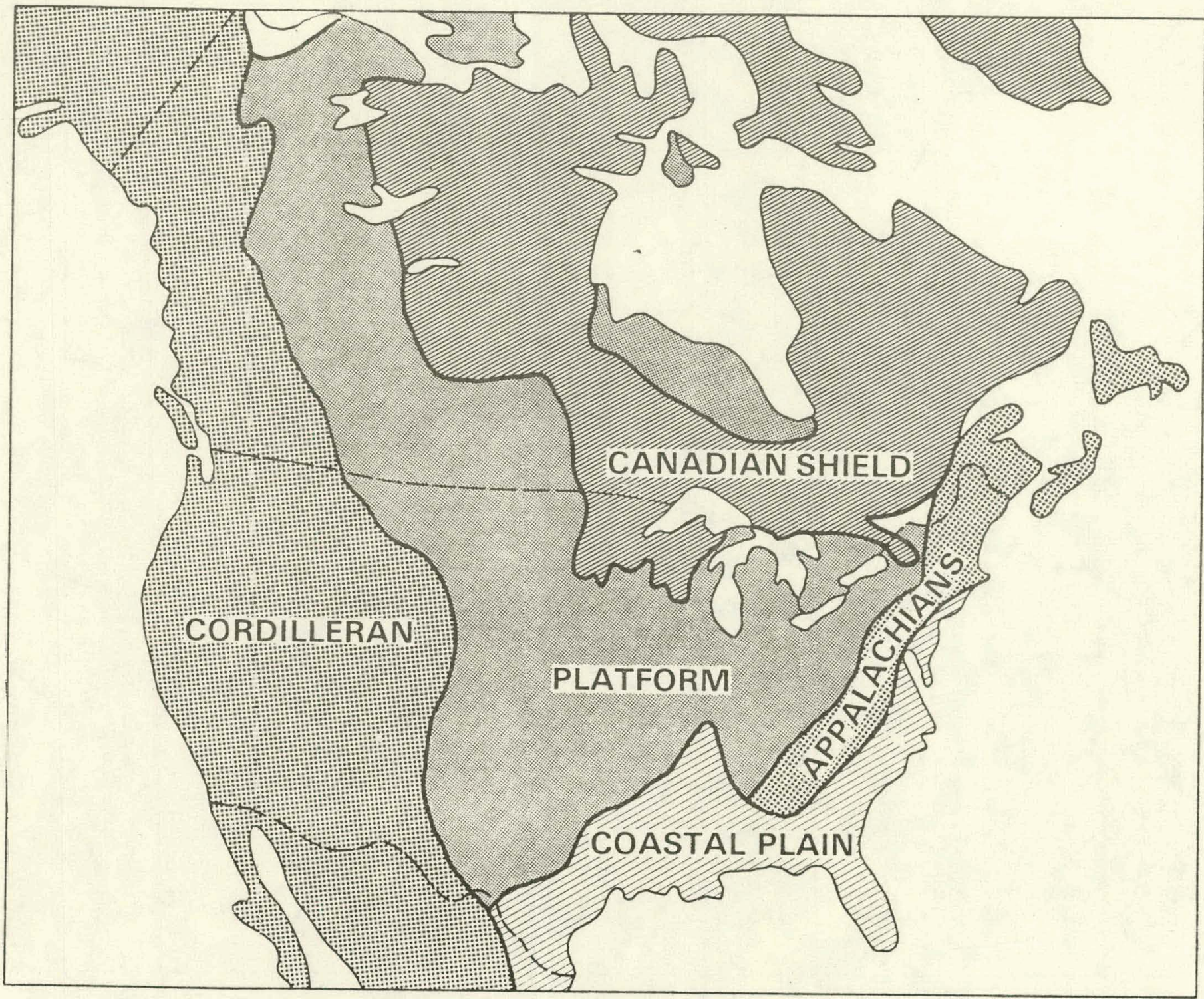

Figure 1. Structural divisions of North America (after Stearn, Carroll, and Clark, 1979). 


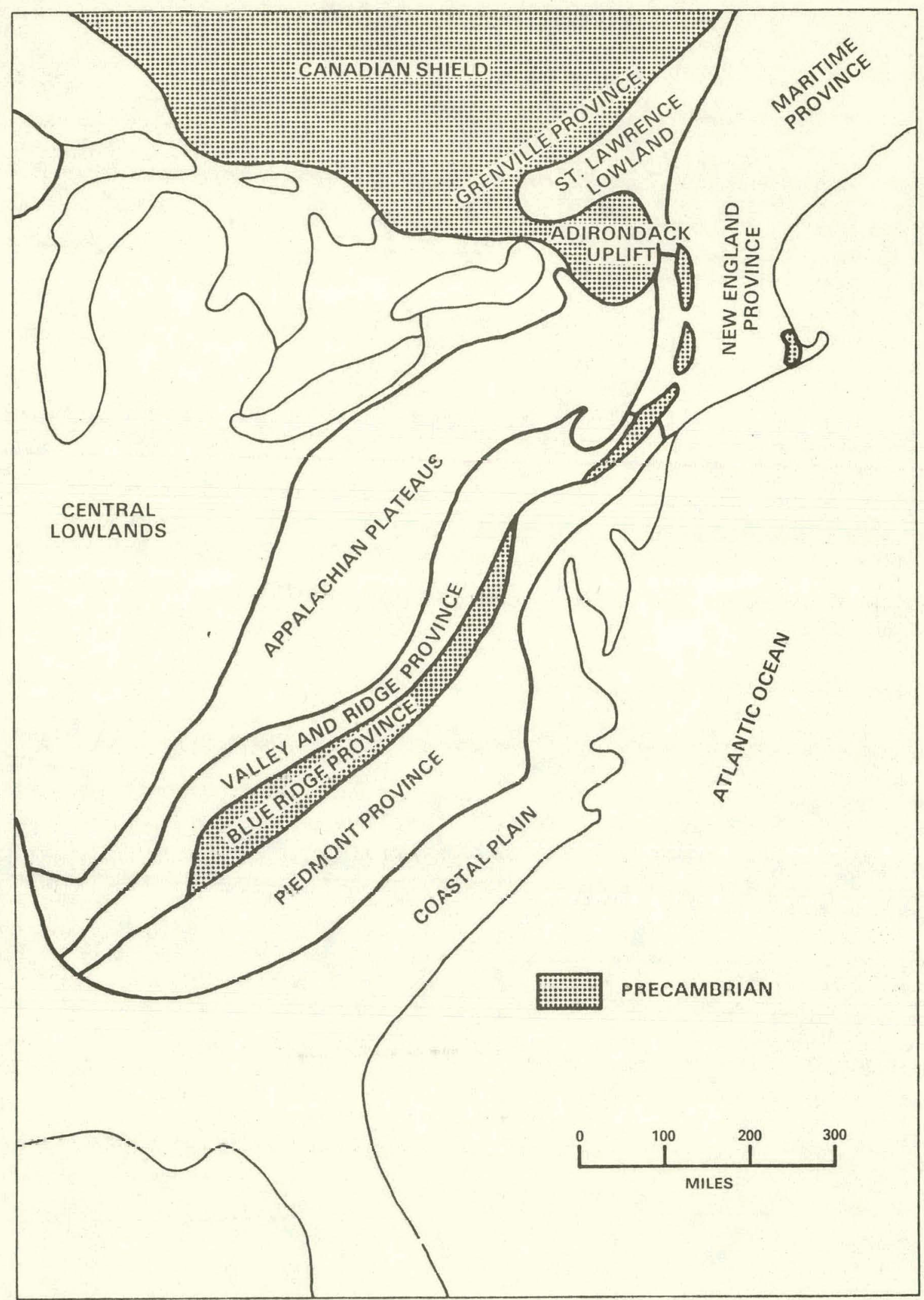

Figure 2. Geologic provinces of the Eastern United States. 


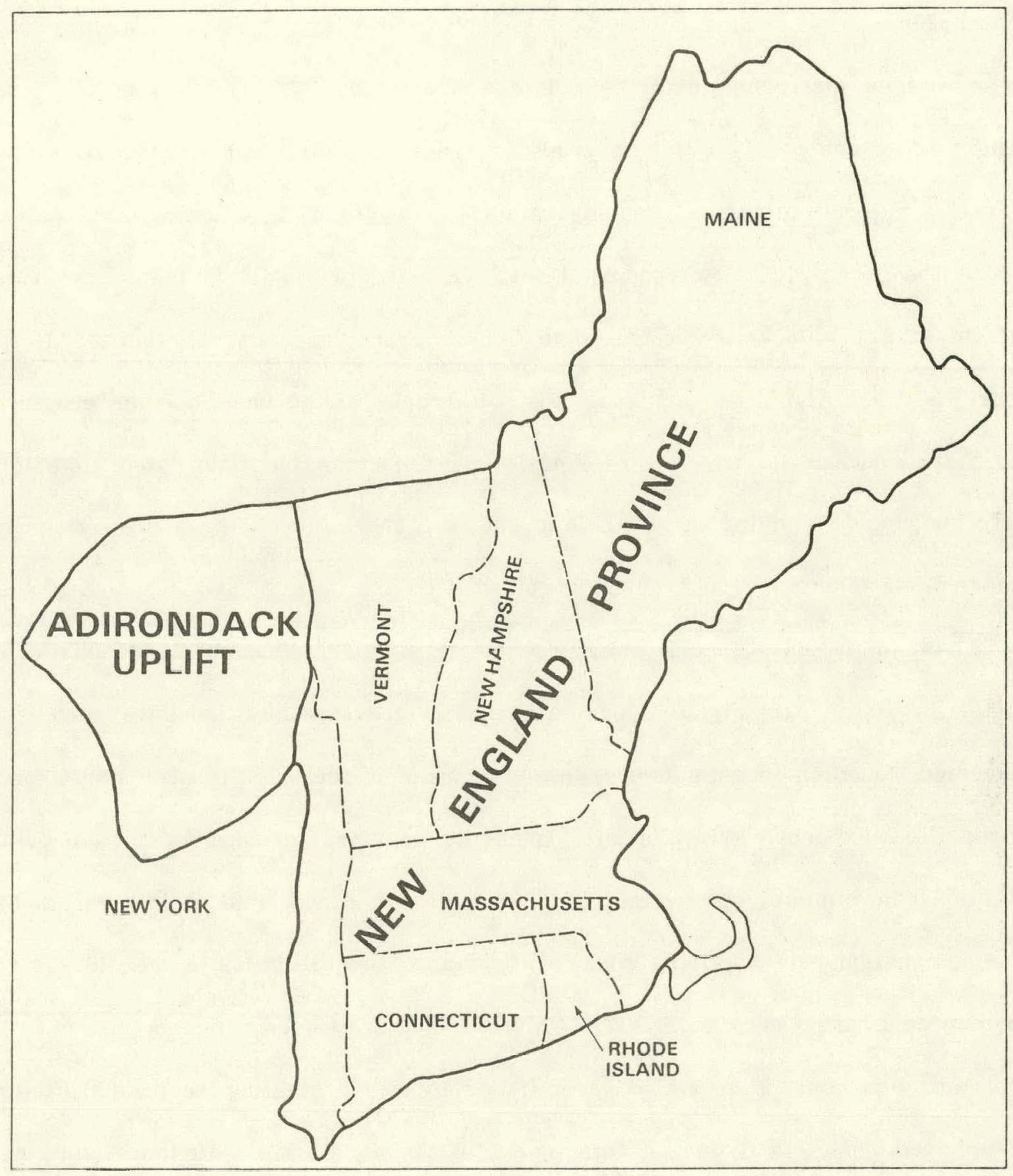

Figure 3. New England province and Adirondack Uplift. 
The Adirondack Uplift constitutes the single largest mass of surficial Precambrian rocks in the northeastern United States. It consists of two contrasting parts (King, 1976). The westernmost part comprises the Adirondack Lowland (also referred to as Northwest Lowland) made up dominantly of medium-grade metasedimentary rocks. The eastern part consists of the Adirondack Highland (also referred to as Central Highland) which consists of high-grade gneisses, syenite, and anorthosite metamorphosed to granulite facies presumably at deep levels of the crust.

The rocks of the Adirondack Uplift are dated primarily by the Grenville orogeny $(1,000 \mathrm{~m} . \mathrm{y}$.$) . Rocks of the Canadian Grenville province, on the other hand, have in$ part been correlated geochronologically with rocks of the vast Superior province lying to the northwest (Figure 6) and many of the Canadian Grenville-dated metamorphics are suspected of having obtained their gneissic character during a pre-Grenville metamorphism. Plutonic rocks are recognized with primary ages corresponding roughly to Elsonian (l,400 m.y.), Hudsonian (l,750 m.y.), and Kenoran (2,500 m.y.) orogeny dates. A large part of the Canadian Grenville province has therefore been considered by some Canadian investigators to be a resurrected tectonically overprinted pre Grenville basement. The Canadian Grenville province is consequently a province defined approximately by a relatively young $(1,000 \mathrm{~m} . \mathrm{y})$ time of late Precambrian metamorphism but containing rocks with primary ages similar to the older structural provinces of the Canadian Shield. Although age dating does not lend support to the suggestion, this concept may also be of importance in evaluating the possibilities for uranium deposits in Grenville-dated rocks of the northeastern United States, particularly for the types of uranium deposits normally associated with older Precambrian terrains. 


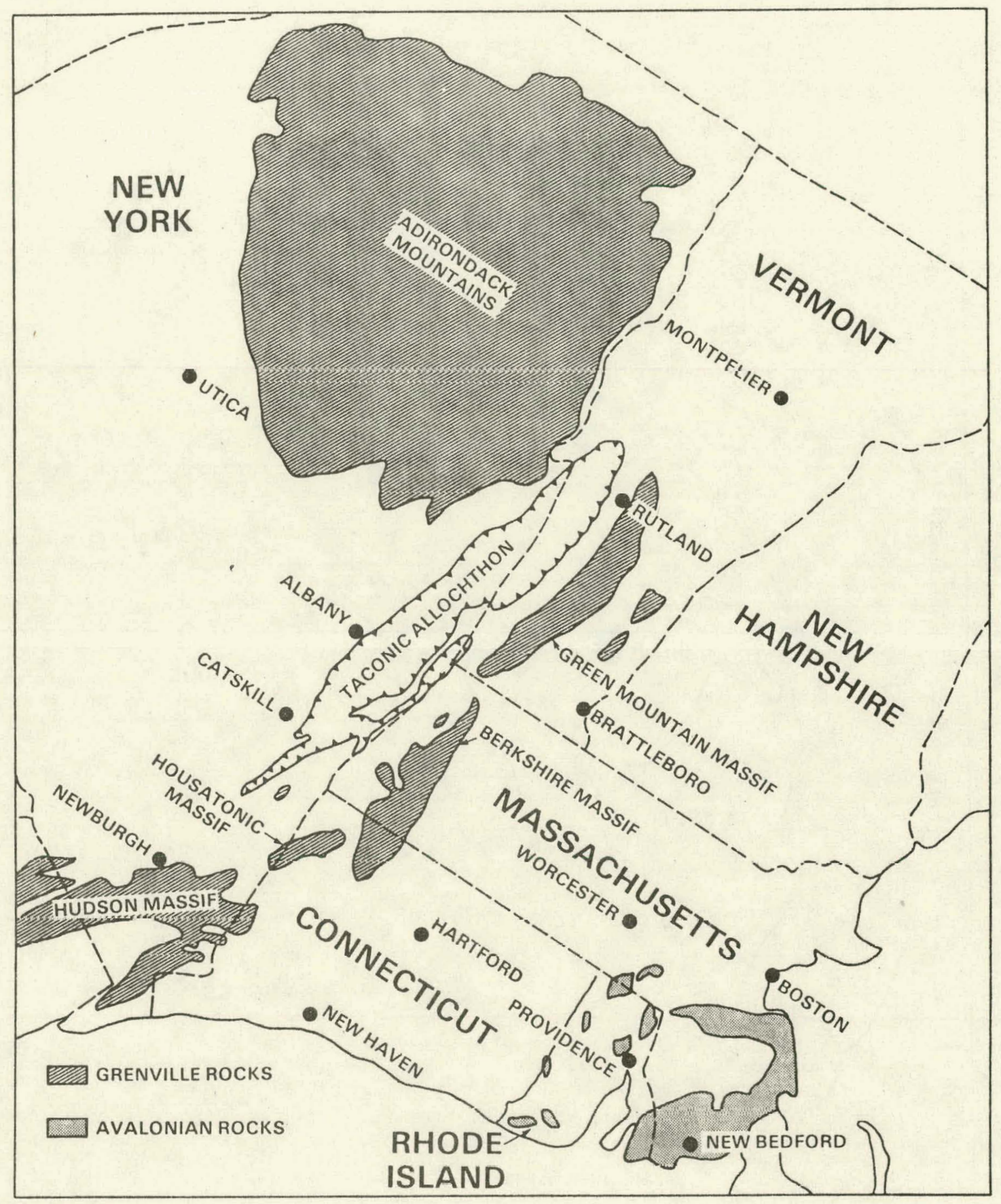

Figure 4. Upper Proterozoic rocks of the Adirondack Uplift and New England province (after Zen, White, and Hadley, 1968). 


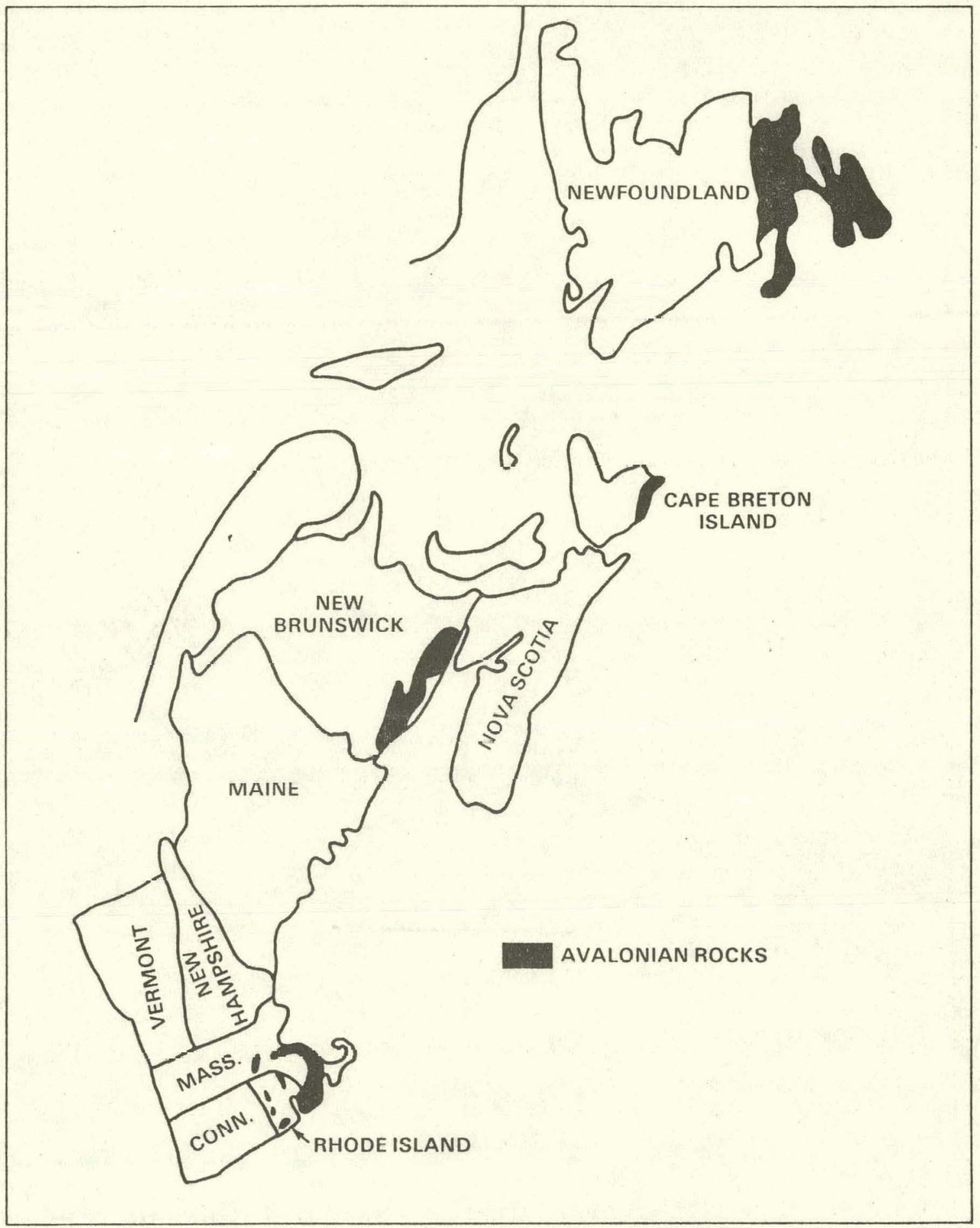

Figure 5. Avalonian rocks of northeastern North America. 


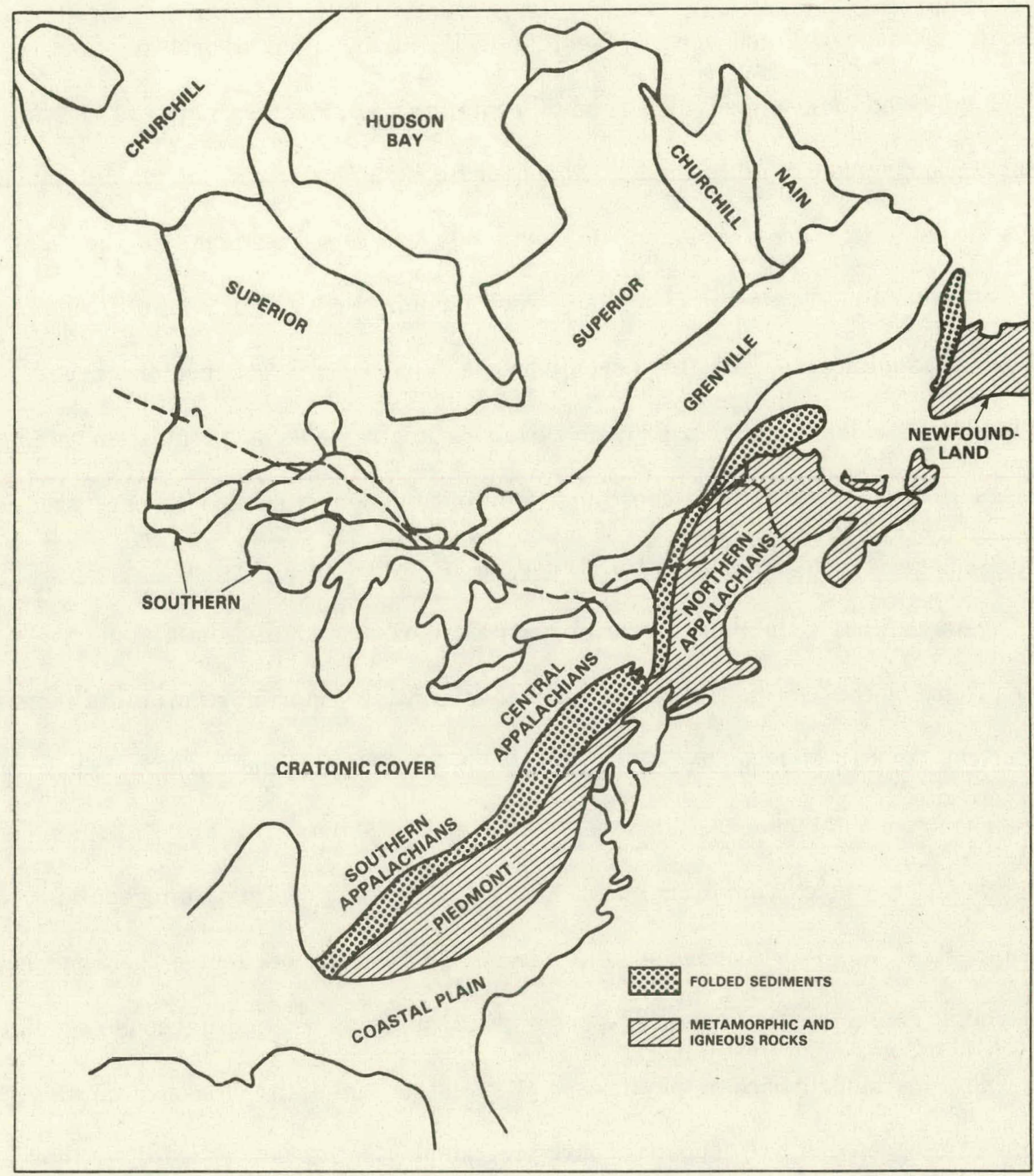

Figure 6. Structural provinces of North America (after Stockwell, 1968, and Stearn, Carroll, and Clark, 1979). 
The Mesozoic and Cenozoic bedded rocks of the New England province are mainly Triassic, Cretaceous, and younger sediments having possible favorability for uranium in sandstones but much less likelihood of containing world-class deposits. They were therefore not included in this study. Phanerozoic stratified rocks of chief importance to this investigation are the Paleozoic sediments and metasediments of the Green Mountains anticlinorium, Connecticut Valley synclinorium, Bronson Hill anticlinorium, Merrimack synclinorium and the Taconic range (Figure 7). The region covered by this report includes Cambrian through Devonian strata made up of miogeosynclinal, eugeosynclinal, volcanic, and subordinate continental deposits, and in part gradational shelf facies, whose general distribution is shown in Figure 8.

Eugeosynclinal Cambrian strata in New England extend in a belt along the eastern flank of the Green Mountains and other similar Precambrian uplifts from Connecticut through Massachusetts and Vermont to the Canadian border. They have also been mapped farther east in these states and in Maine (King and Beikman, 1976). To the west, they are transitional with Cambrian miogeosynclinal (miogeoclinal) rocks in east-central New York and near the Vermont-New York border. The eugeosynclinal rocks comprise for the most part a thick sequence of argillaceous and clastic rocks, now metamorphosed to phyllites and schists, containing volcanic units. The Cambrian miogeosynclinal deposits consist of basal clastics succeeded by a thick sequence of carbonate that extends into the Lower Ordovician. In the Tacnnic range the eugeosynclinal rocks appear to be transitional with the miogeosynclinal carbonates in allochthonous blocks believed to have been transported by gravity sliding onto a sea floor where Middle Ordovician sediments were still accumulating (King and Beikman, 1976). 


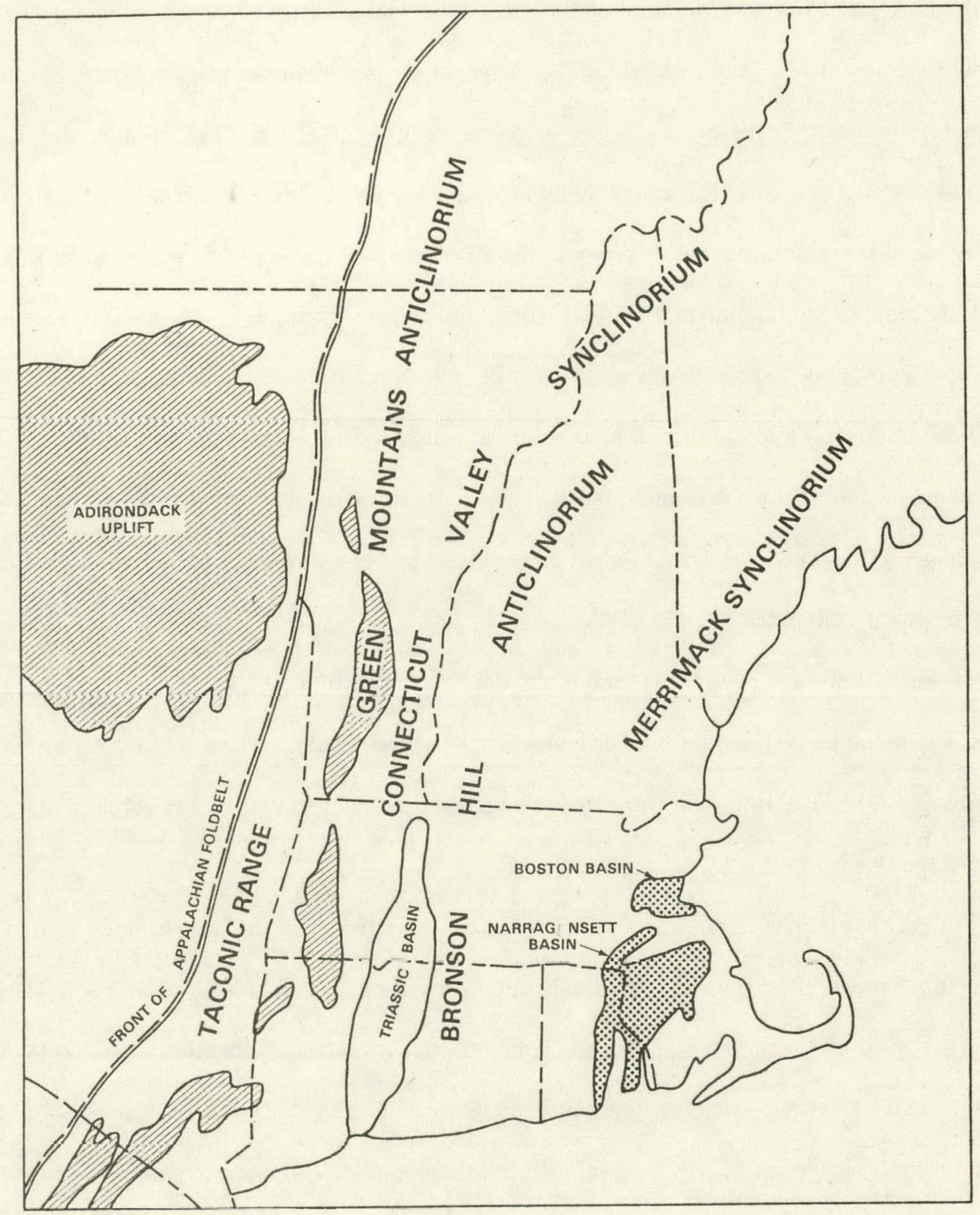

Figure 7. Tectonic features of Northeastern United States. Anticlinoria and synclinoria define distribution of Paleozoic geosynclinal rocks (after King and Beikman, 1976). 
Ordovician eugeosynclinal rocks occur in all the New England states, reaching a thickness in excess of 20,000 feet, (King and Beikman, 1976). They are predominantly phyllites and schists containing interbedded volcanics and sandstone. The volcanic component, much of which is tuffaceous, increases eastward. The Middle Ordovician in northeastern Maine, where the sediments are mainly shales, tuffs, and volcanic breccias, contains many fossils indicative of a eugeosynclinal shoal area. Tuffaceous sediments in the eugeosyncline may have originated from volcanic island arcs formed in the Bronson Hill anticlinorium region from New Hampshire southward. Middle Ordovician graptolitic shales overlie the volcaniss in northern Maine. Lower Ordovician miogeosynclinal rocks are largely carbonates, whereas the Middle Ordovician sequence is one of limestone and graptolitic shale giving way to coarser clastic rocks. The overlying Upper Ordovician passes upward into red beds which are in part continental.

Undifferentiated Silurian-Ordovician deposits of northeastern Maine comprise a thick sequence of eugeosynclinal calcareous silty and sandy flysch lacking in volcanic material. These sediments were deposited far from any tectonic or volcanically aclive areas.

Eugeosynclinal Silurian deposits are most prominent in the Merrimack synclinorium where they reach a thickness of more than 15,000 feet. The rocks are mainly slates and schists containing minor sandy units and volcanics. Volcanic rocks, which dominate nearer the coast, are well displayed in the Eastport area of Maine where they show little evidence of metamorphism. Metamorphism increases toward the southwest. In Vermont and New Hampshire the Silurian contains quartz sandstones and carbonate. The Silurian miogeosynclinal rocks are predominantly clastic, in part nonmarine. They thin and intertongue westward with shales and limestones. 


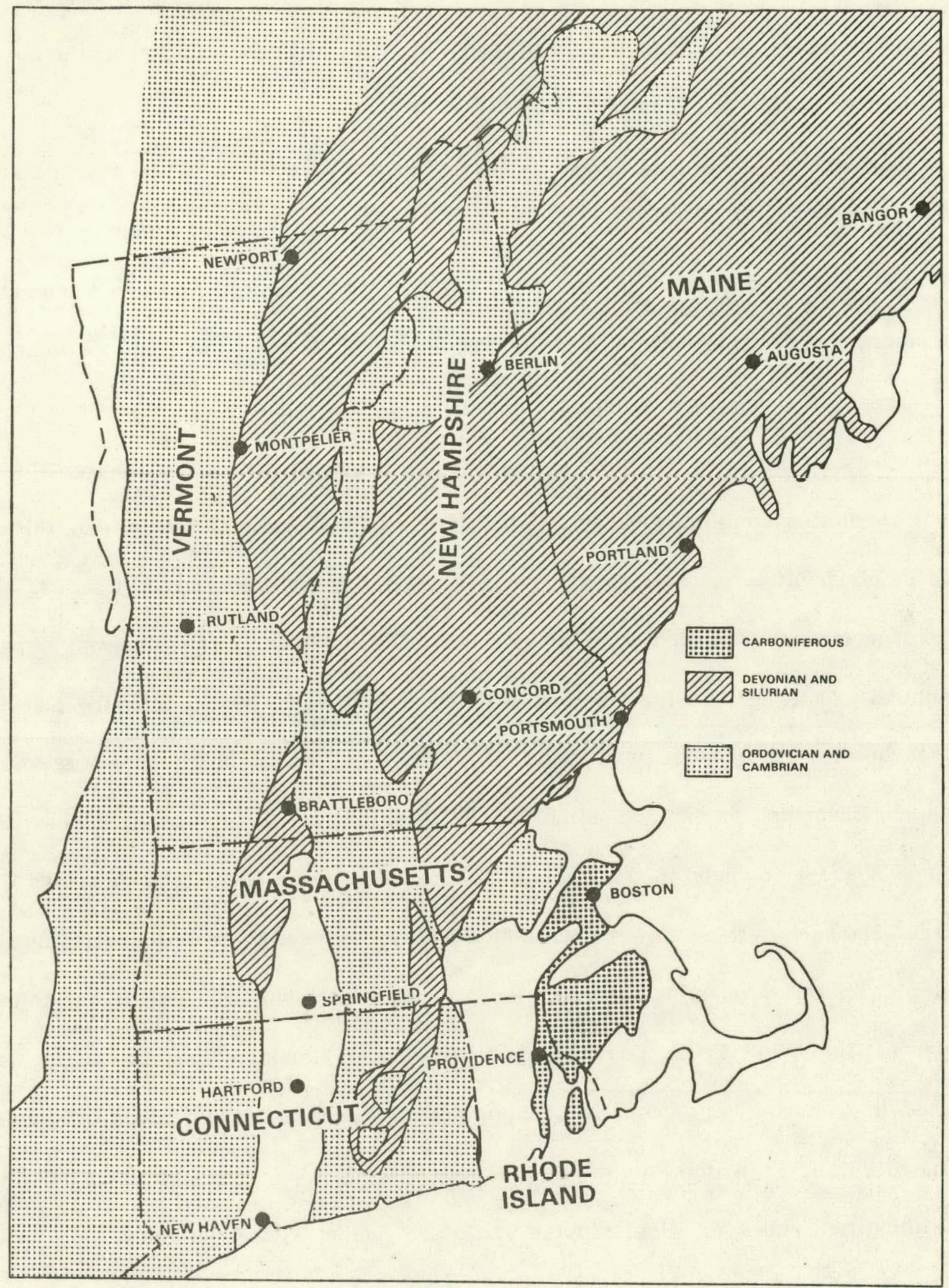

Figure 8. Generalized distribution of Paleozoic stratified rocks in the New England province (after Zen, White, and Hadley, 1968). 
Strata mapped as Devonian-Silurian are extensive in New England and most likely contain rocks of both ages. Calcareous silty and sandy eugeosynclinal rocks predominate within these units.

Devonian eugeosynclinal deposits mark the end of eugeosynclinal subsidence prior to the Acadian orogeny in New England. All are Lower Devonian. Phyllites and schists dominate in the Connecticut Valley synclinorium in eastern Vermont. These are more calcareous in the west and more quartzose in the east. Volcanics are rare in this sequence except for metavolcanic amphibolite in the eastern part. In Northern Maine, the Devonian comprises a thick sequence of deep-water shaly and sandy turbidites containing sandy shoal-water deposits in places overlain by thick masses of rhyolitic volcanic rocks probably derived from island-arc volrannes.

This sequence is succeeded by shallow-water and hrackish-water sodimento. Stratigraphically eastward, in the Bronson Hill anticlinorium of New Hampshire and central Massachusetts, the Devonian is made up of shaly and sandy beds containing volcanic tuffs and breccias, variably metamorphosed to phyllite, schists, and gneisses. Devonian rocks are also found in the Merrimack synclinorium in New Hampshire and eastcentral Massachusetts. Lower Devonian rocks are sparse in the miogeosyncline and craton. The most prominent part of the Devonian platform sequence is the thick wedge of Middle and Upper Devonian partly-continental clastics that forms the Catskill delta. These rocks contain uranium deposits in their sandy facies but arc not included within the framework of the present study.

Stratified rocks of Mississippian age do not occur within the study area. They do, however, contain sandstone-type uranium occurrences in eastern Pennsylvania. 
Pennsylvanian strata of New England are restricted to the Narragansett and Boston basins of Massachusetts and Rhode Island where they consist of thick, steeplyfolded, sandstones and shales. They contain fossil plants and coal beds largely altered to graphite and are intruded by late Paleozoic granites. Although the favorability of the Pennsylvanian sediments in New England for sandstone-type uranium deposits has not reportedly been tested, sandstones of this age contain deposits outside of the study area in eastern Pennsylvania.

No Permian sediments or metasediments occur within the New England province, although some units in the Boston-Narragansett basin region have questionably been assigned this age.

\section{PHANEROZOIC PLUTONIC ROCKS OF NEW ENGLAND}

Plutonic rocks are widespread in New England. They are represented chiefly by granites of lower-middle and upper Paleozoic, and Mesozoic, ages.

Ordovician and Cambrian $(400-500$ m.y.) granites occur throughout the length of the Appalachian region. Several different plutonic series have been mapped (King and Beikman, 1976):

(1) The Highlander oft Plutonic Scrice in the Connecticut Valley synclinorium of western New Hampshire consist of chloritized quartz monzonites intruding Ordovician rocks.

(3) The Olivorian Plutonic Seriss in the Rrnnsnn Hill anticlinorium in New Hampshlre, Massachusetts, and Connecticut consist of massive granites in a series of elongate domes, intruding volcanics (Ammonoosuc). The granites are mantled by gneisses 
believed to be metasomatized volcanics, and are thought to have formed at deeper crustal levels than the Highlandcroft Plutonic Series.

(3) The Cape Ann, Peabody, and Quincy Granites of the Boston area are alkalic rocks, unaffected by the Acadian orogeny, similar to younger alkalic granites to the northwest.

The Oliverian plutonic rocks have yielded $\mathrm{Pb} / \mathrm{Pb}$ and $\mathrm{Rb} / \mathrm{Sr}$ ages of 440 to $450 \mathrm{~m} . \mathrm{y}$. and the alkalic granites $\mathrm{Pb} / \mathrm{Pb}$ ages of 435 to $452 \mathrm{~m} \cdot \mathrm{y}$.

Considerably more abundant are the middle Paleozoic granites, with ages of 350 to $400 \mathrm{~m} \cdot \mathrm{y}$. (Devonian) represented chiefly by the New Hampshire. Plutonic Series (King and Beikman, 1976). These occur in, as well as east of, the Bronson Hill anticlinorium and extend into Massachusetts, Maine, and nor theastern Vermont. They include early-formed concordant gneissic bodies, such as the Bethlehem Gneiss and Kinsman Quartz Monzonite, and later cross-cutting binary granite plutons, The granites have been dated at $380 \mathrm{~m} . \mathrm{y}$. in New Hampshire and at $358 \mathrm{~m} . \mathrm{y}$. in Maine (Mt. Katahdin pluton). The coastal plutons of eastern Maine evidently belong to a younger, late Devonian, series.

The Narragansett Pier Granite and Westerly Granite are the only known upper Paleozoic granitic rocks in New England. The Narragansett Pier Granite intrudes Pennsylvanian rocks of the Narragansett basin in southern Rhode Is land and has been dated at 240 to $299 \mathrm{~m} . \mathrm{y}$. (Permian) by $\mathrm{K} / \mathrm{Ar}$ and $\mathrm{RB} . / \mathrm{sr}$ methods.

Mesozoic plutons are manifest in New England in central New Hampshire and nearby Vermont and Maine, where they are represented by the White Mountain Plutonic Series. The rocks consist of cross-cutting ring dikes and cauldron subsidences, partially coalesced into a batholith. They are alkalic in composition, chiefly quartz 
syenite and alkalic granite. Age dates range from about $180 \mathrm{~m} . \mathrm{y}$. (Early Jurassic) to as young as $110 \mathrm{~m} . \mathrm{y}$. (Early Cretaceous), thus overlapping the age dates of 84 to 1 $123 \mathrm{~m} . \mathrm{y}$. obtained on the Monteregian intrusives of Canada to which the White Mountain rocks are seemingly related. The most prominent unit is the Conway Granite, which has a relatively high thorium and uranium content and has been studied as a possible low-grade source of these elements.

URANIUM IN GRENV-ILLE-DATED ROCKS OF THE NORTHEASTERN UNITED STATES

Favnrahility of the Grenville-dated rocks of New York and New England for uranium has been examined by several investigators. Adams, Arengi, and Parrish (1980), using the pegmatite deposits at Bancroft, Canada, for comparison, considered the Adirondack Highland and the Grenville-age units of the Appalachian fold belt favorable for similar deposits. A list of 16 known pegmatite localities in Grenvillian rocks of New York is appended to their report. Grenville (i.e. Grenville-dated) terrane has also been identified as promising for uranium in granitic rocks by Greenberg, Hauck, Ragland, and Rogers (1977) within the Adirondack Mountains, the Hudson massif of southeastern New York, the Housatonic massif of Connecticut, and the Green Muüntain massif of Vermont:

Favorability of Grenville-dated rocks for Proterozoic unconformity-related deposits has been examined by Kalliokoski, Langford, and Ojakangas (1978), who concluded that although the Granville gneisses of the St. Tawrence lowlands and the Adirondack Mountains constitute suitable host rocks, the absence of proper cover rocks reduces their favorability: to a low level. A similar conclusion was reached with respect to the Grenville rocks of the northern Appalachians.

Nutt (1980) has reviewed the uranium potential of the Adirondack region and. 
concluded that pegmatites constitute the dominant radioactive occurrences there but that tonnages of individual pegmatites were too low to encourage future exploration. Locality data from Grauch and Zarinski (1976) applicable to the Adirondack are given in his report. Unconformity-related deposits were not ruled out, but characteristics comparable to those favoring uranium occurrence in the classic areas are unknown or unrecognized. The leucogranitic gneisses (alaskites) of the Adirondacks were considered environmentally favorable, but their presently low uranium content (4.93 ppm U) was judged to be an unfavorable indication.

\section{CANADIAN GRENVILLE PROVINCE}

The Canadian Grenville provinne which is considorably larger in ils surflulal extent than that of the adjoining Grenville area of the northeastern United States, contains noteworthy uranium deposits whose characteristics give guidance to recognition of favorable settings for similar deposits in the Adirondack Uplift. and nearby :Grenville massifs. The geological constitution of the province also has given encouragement to a broader outlook on possibilities for uranium occurrences in the lattar arens. Variouo considerations will be covered in this section of the report and will also be given further attention in the section on the Adirondacks.

The Grenville province is a northeast-trending segmont of the southeaslerii flank of the Canadian Shield in excess of 1,000 miles long and 200 miles wide, yielding prevailing radiometric ages near $950 \mathrm{~m} . \mathrm{y}$. (Stockwell, 1968). It is bordered to the northwest by older rocks which in places are transitionally altered by the Grenville orogeny and isotopically modified to conform with Grenville ages. The struc:tural fabric of the province has a general northeasterly grain which is not always uniform and the rocks are characteristically marked by high-grade regional metamor phism. 
The province contains many different lithologies, most of which have been subjected to and manifest evidence of Grenville metamorphism and deformation during late Helikian time. Many of the rocks appear to be older than their Grenville age indicates. Correlatives of Superior province rocks (dated by the Kenoran orogeny; 2,500 m.y.) and Churchill and Southern province rocks (dated by the Hudsonian orogeny; $1,750 \mathrm{m.y.)}$ have been identified within the Grenville province particularly near the Grenville Front, and its history probably extends back into the Archean.

A broad three-fold division of the Grenville province is generally recognized, namely (l) a younger complex of metasediments dominated by marbles, paragneisses, quartzites, and amphibolites; (2) an older remobilized basement of granitic and charnockitic gneisses, in part containing pretectonic rocks, including anorthosites, intrusive into the overlying metastratified sequence; and (3) a relatively young sequence of plutonic rocks that syn- and post-tectonically intrude the' Grenville Group. The younger metasediments comprise the Grenville Group (formerly Grenville Series), which is distributed over only a small part of the province, making up about 10 percent of the total area. These rocks occupy a-more or less circular area within a radius of about 135 miles of Ottawa, extending southward, through the Frontenac Axls inlo the Adirondack Lowland, beyond which they nncur as isolated basins or synforms within the Adirondack Highland. The rocks are considered to be preHudsonian (1,750 m.y.) and hence probably Aphebian in age (Wynne-Edwards, 1969). Marblo is very prominent in the Grenville Group; however, its usefulness in distinguishing basement from the metasedimentary cover rocks is somewhat muted by its occurrence also in older rocks of the Sudbury, Bruce, and Cobalt Groups that are transected by the Grenville Front (Appleyard, 1965). 
Within the Mont Laurier and Kempt Lake map areas, comprising 13,000 square miles of the Grenville province northeast of Ottawa, several tectonically distinct categories of rocks have been recognized (Wynne-Edwards, 1969), namely, (1) pretectonic (with respect to the Grenville orogeny) basement complex in granulite facies, (2) pretectonic basement complex in amphibolite facies, (3) pretectonic basement complex modified by pretectonic intrusions, (4) pretectonic sedimentary rocks, (5) pretectonic intrusions, (6) syntectonic intrusions, and (7) post-tectonic intrusions. These rocks are considered typical of the Grenville province as a whole, being made up of plutonic and high-grade metamorphic rocks.

The post-tectonic intrusions, comprising chiefly diabase dikes, are probably Hadrynian ( $750 \mathrm{m.y.}$ ) in age (Wynne-Edwards, 1969). The syntectonic intrusions, which consist of granite, syenite, alkali syenite, gabbro, migmatite, and minor pegmatite are close in age to the average value for the Grenville orogeny (950 m.y.). The pretectonic intrusions, which are metamorphosed and deformed, have been identified with the Elsonian orogeny $\left(1400 \mathrm{~m} . \mathrm{y}_{\text {. }}\right)$ and assigned a Paleohelikian age. They consist of anorthosite, mangerite, and monzonite. All the above rocks are intrusive into the Grenville Group, which is, therefore, considered to be older.

The basement complex of quartzofeldspathic and amphibolite gneisses is believed to represent a combination of acid and basic lithologies that correlate respectively with granites, and other silicic rocks, and greenstones of the Superior province to the northwest (Wynne-Edwards, 1969). On this basis, the basement complex has been assigned to the Archean.

The Grenville Group comprises a marble-rich metasedimentary sequence deposited in a dominantly marine environment. It is renowned for its variety of mineral deposits and exceptionally large concentrations of nepheline syenite, 
particularly in the Bancroft-Madoc area (Figure 9). Deposits of apatite, corundum, iron, marble, mica, molybdenum, talc, fluorspar, garnet, graphite, and uranium have been discovered in these rocks, and some of these deposits have on occasion been mined. Radioactive mineral occurrences have been known in the Bancroft region for many years, and uranium has been produced intermittently on a large scale since 1956 from pegmatite.

The pegmatite uranium occurrences are obviously germane to this report. Favorability for this type of deposit has been suggested for the Adirondack Highland and for Grenville-age units of the Appalachian fold belt by Adams, Arengi; and Parrish (1980). The occurrences of graphite, however, are perhaps less obviously but nevertheless equally pertinent from the standpoint of calling at tention to reducing environments in rocks in the Adirondack Lowland, and in correlative lithologies in the Adir ondack Highland, that might be conducive to formation of uranium deposits. The model(s) for the graphite-related type of occurrence(s), interestingly, exists in Aphebian sediments of the Kaipokok Bay-Big River area of Labrador and in Cenozoic sediments of the Pena Blanca area, Chihuahua, Mexico, the latter being a somewhat more hypothetical situation because of the more speculative inferences regarding the origin of uranium deposits there.

In the following sections, the geology of these areas and their uranium deposits will be described in sufficient detail to derive some perception as to how the geologic environments serve as models for uranium emplacement. This will be followed by a general description of the geology of parts of the Adirondack Uplift that exhibit geologic characteristics similar to those in the model areas and thcrefore influencing the uranium favorability of that region. 


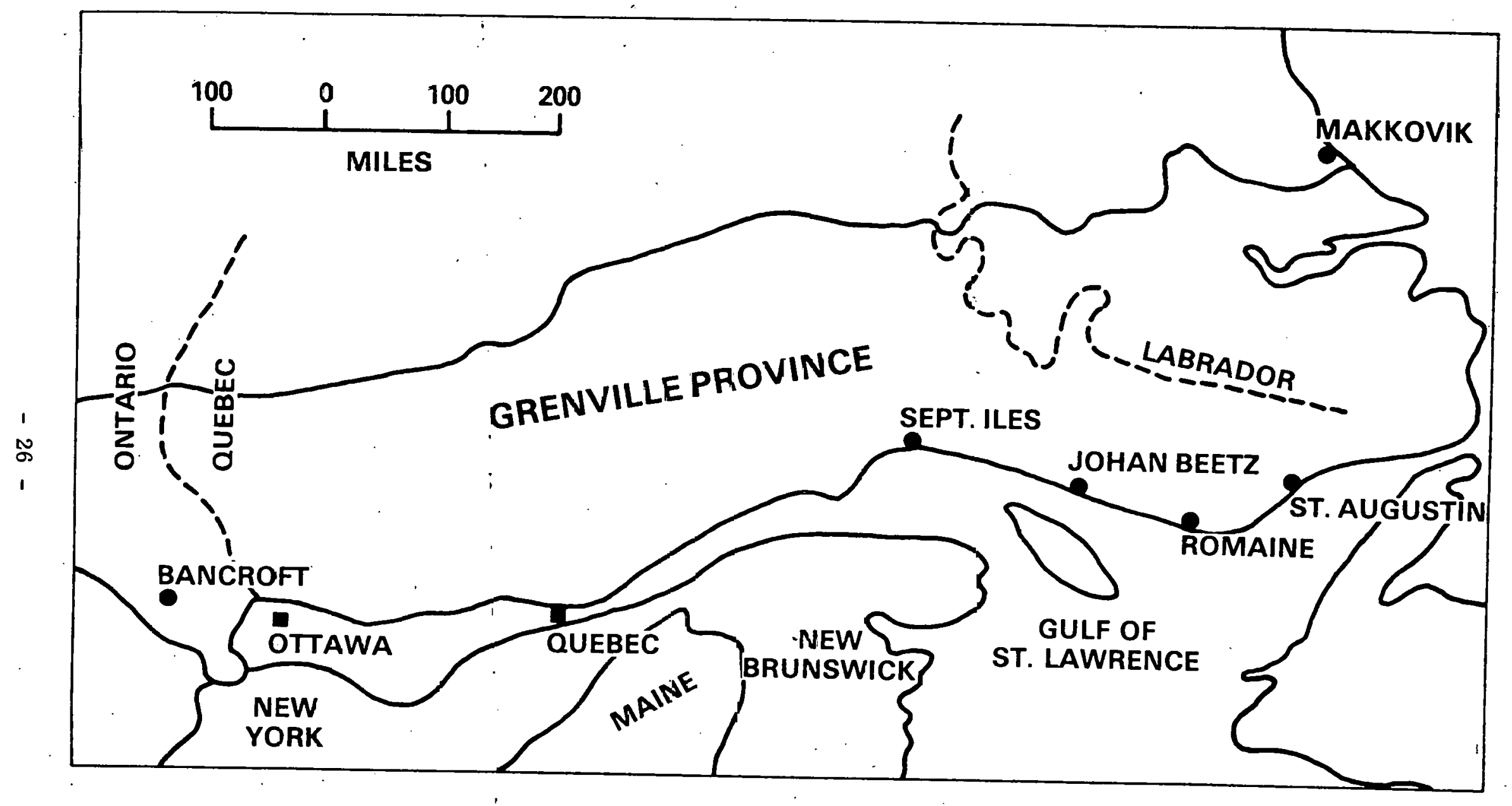

Figure 9. Uran:um districts cf the Grenville province, Canada 
Syntectonic granites of the Grenville province are host to a number of important uranium deposits in the Bancroft area of Ontario. Uranium occurs chiefly in pegmatitic granite dikes which intrude Grenville Group metasediments. It is also found in replacement deposits in metasomatized zones of the metasediments, particularly in marble, which commonly exhibits skarn development, and in pyroxenite, which is a product of marble metasomatism. Hydrothermal calcite-fluorite-apatite veins also contain uranium especially in the syenitized gneisses of the Grenville Group. The dominant uranium minerals are thorian uraninite and uranthorianite. The following brief account of the uranium occurrences is based on Hewitt's publication (1957).

The Bancroft area contains a number of large batholithic and sheet-like intrusive bodies of granite. Granitic dike-like bodies that project from the batholithic and sheet-like intrusives are pegmatitic in places but do not show lithologic zoning or segregation. Compositionally, they grade from syenite, sometimes alkalic, to granite. Granitization and syenitization of the Grenville Group paragneisses and other metasediments is commonplace, forming hybrid mixed gneiss zones marginal to the major batholithic complexes and intrusive sheets. These rocks appear to be favorable for the deposition of uranium in pegmatitic dikes. The chemical composition of the host rocks intruded by pegmatite and the structural position of the dikes in them are evidently the two most important factors governing the uranium favorability of the pegmatites. Rocks rich in magnetite, hornblende, and pyroxene, such as limy paraamphibolite, and metagabbro, appear to be most effective in controlling uranium deposition. The ferroan minerals in these rocks seem to influence emplacement of the uranium, particularly where the iron minerals are assimilated from the host rocks. and recrystallized in the dikes. 
The competent impermeable nature of the metagabbro and amphibolite is also a contributing factor by physically confining the dike material and thereby concentrating the uranium mineralization. In more permeable sandy paragneiss the mineralization becomes widely distributed in migmatite veinlets in the host rock and is consequently more diffuse. Uranium distribution is also favored by shearing and fracturing, particularly of dikes that cut garnet-sillimanite gneiss.

Although the mechanism is not clear, uranium appears to be precipitated by some effect of ferrous iron present in the iron-rich wall rocks and is commonly enriched in pyroxene- and magnetite-rich ore shoots. This is a characteristic feature of both the Bicroft and Faraday mines. Hematitization and red coloration of feldspar accompany uranium mineralization at Bancroft. In vein-type deposits of simpler mineralogy, such as at Limousin, France, where pitchblende, rather than uraninite, and pyrite predominate, uranium ore zones are also marked by the development of hematite in the enclosing rocks (Sarcia et al, 1958). The hematite at Limousin is thought to be due to the oxidation of pyrite and to early alteration of wall-rock biotite during syenitization of rocks rich in iron.

Reaction of $a$ ferrous:ferric and uranous: uranyl couple may account for uranium precipitation and formation of hematite at Bancroft, but it explains neither the precipitation of thorium in the uranothorianite and uraninite nor the occasional presence of thorite, pyrochlore, and fergusonite.

According to Hewitt (1957), marble contains no important uranium-bearing dikes but is host to metasomatic replacement deposits. The marble is commonly silicated containing up to 50 percent of silicate minerals such as diopside, tremolite, and phlogopite. Pyrite and graphite are also present, the latter in mineable quantities (in past years) in places. Lime-silicate rock, as distinct from silicated 
marble, is also found. This is the product of contact metamorphism or metasomatism and is accompanied by iron-rich skarns. Pyroxenite occurs in bands where metasomatic alteration of marble has taken place. This is a favorable host rock for uraninite deposits.

A variety of minerals occurs in these siliceous marbles. Diopside, tremolite, phlogopite, scapolite, serpentinite, vesuvianite, garnet, quartz, feldspar, pyrite, pyrrhotite, apatite, chondrodite, spinel, titanite and graphite are associated with the granular silicated marbles. Diopside, augite, hornblende, scapolite, garnet, magnetite, phlogopite, vesuvianite, spinel, apatite, wollastonite, and forsterite are associated with the tactite skarns. The metamorphic pyroxenites are composed dominantly of diopside and augite, and also contain phlogopite, scapolite, titanite, apatite, carbonate, pyrite, and feldspar.

The initial stages of intrusion in the Bancroft area are marked by injection of syenites and syenite pegmatites and by metasomatic syenitization of paragneiss and amphibolite. These were followed by extensive emplacement of granite and accompanying granitization, with which the uranium occurrences are associated. During this latter episode assimilation of nepheline rocks took place resulting in the formation of hybrid syenites (Gittins, 1967). Nepheline syenites of igneous origin occur near the batholithic margins. In contrast to alkalic rocks of this type elsewhere in the world, these do not contain notable concentrations of zirconium, fluorine, niobium, or rare earths. Some of the nepheline syenites are gneissic and are evidently regionally metamorphosed equivalents of the igneous type, whereas others are probably metasomatically nephelinitized rocks. Where nepheline rocks are in contact with marble, skarns containing diopside, pyroxene, and garnet may occur. A complex assortment of rocks, in addition to those already mentioned, is present in the region, including nepheline pegmatites which are devoid of uranium. 
Robinson and Hewitt (1958) have noted that zircon is abundant in the granitic uranium deposits at Bancroft and that its distribution is similar to that of the uranium minerals. In most ore shoots, the zircon content increases with the increase in uranium minerals, and zircon is also disseminated, though more sparsely, throughout the pegmatitic dikes. No quantitative data are given to indicate the extent and degree of zircon mineralization at Bancroft; therefore, only a qualitative comparison can be made with other deposits in which both zirconium and uranium are found. High zirconium concentrations have been recognized in a number of uranium deposits associated with alkalic rocks, e,g. at. Ilimaussaq, Grccnland aud Pucos dé Laldas, Brazil. Both areas contain significant mineable or economically marginal uranium deposits. Because of the geochemical similarities of the two elements, the zirconiumuranium association has been pointed to as a possible diagnostic feature of uranium favorability of plutonic environments by Adler (1977). It may be a useful criterion for evaluating the uranium potential of pegmatite deposits in the northeastern United States.

The Bancroft area in general reflects a petrogenetic region with (1) an intricate and involved igneous history, (2) a concomitant development of a variety of mineral deposits, (3) a large concentration of nepheline syenitc, and (4) extensive metasomatism. An area with such wide-spread intrusion, metasomatism, replacement and mineralization should not be difficult to recognize elsewhere.

Because the Adirondacks have bün so extensively studied, it is unlikely that magmatic activity of the magnitude and intensity observed at Bancroft would be unperceived, unless such activity. was ronted more dccply and had not yet been exposed surficially to an appreciable extent by erosion. 
The relationships at Bancrof $t$ also suggest that an abundant and fár-reaching plutonic activity may be required to produce pegmatites of sufficiently large uranium content to be commercially interesting. Furthermore, unless Rossing (South West Africa), which has pegmatitic characteristics, can be equated with Bancroft or other pegmatites, there is no convincing evidence that pegmatite environments constitute a very productive source of uranium. Such a viewpoint, even if practical is nevertheless pessimistic and somewhat pragmatic and not in keeping with the purpose of this report. Metasedimentary, migmatitic, and plutonic environments of the Adirondacks should, therefore, be studied for their possible pegmatite uranium potential using the geological characteristics of the Canadian Grenville province for guidance. The question of uranium origin is of considerable importance in favorability concept development for Grenville terrain. The marble-rich metasedimentary rocks of the Grenville Group in the Bancroft area interfinger at their base with the upper part of a metavolcanic sequence, containing metaconglomerates and metasandstones, derived locally from tectonically active volcanic areas (Lumbers, 1967). The oldest known lavas are dated at about $1,300 \mathrm{~m} \cdot \dot{y}$. These rocks were subjected to Grenville metamorphic, plutonic, and tectonic events. The metavolcanics are part of an extensive metasedimentary-volcanic belt that trends northeasterly for over 200 miles from the Paleozoic cover in southeastern Ontario to southwestern Quebec. The belt, which is as much as 100 miles across, is known as the Ottawa River remnant.

The volcanics of this belt appear to have been extruded into à dominantly maine sedimentary environment containing arkoses and other sediments locally eroded from Intermediate to felsic volcanic centers. The major plutonic activity in the region postdates the earliest manifestations of the Grenville orogeny but is generally considered as contemporaneous or syntectonic. The oldest plutonic rocks form a biotite-diorite 
series restricted to those parts of the area rich in metavolcanics. This series forms a distinct age group, dated about $1,250 \mathrm{~m} . \mathrm{y}$. Subsequent activity involved emplacement of nepheline syenite masses and late gabbro and diorite stocks, all of which could be related genetically, followed by syntectonic quartz monzonite and potassic granite plutons $(1,125$ m.y.) which underly much of the migmatitic terrain developed during Grenville metamorphism. As plutonic activity waned, a relatively young series of pegmatitic granites and syenites, and pegmatites, all of which are about 1,050 m.y. old, were emplaced together with calcite-apatite-fluorite veins in the metamorphic torraino.

Although the origin of the uraniferous pegmatites and their associated granitic and syenitic plutonic rocks at Bancroft is unknown. the spatial assonciation of oarlicr diorites with volcanic terrain, the presence in the Bancroft pegmatites of fluorite, which is a common component of volcanic rocks, and the preponderance of underlying metavolcanics in the region, suggest that the granitic rocks, derivative pegmatites, and uranium giving rise to the Bancroft deposits could be a product of the syntexis. of voloanic rocks.

\section{OTHER GRENVILLE PROVINCE URANIUM DEPOSITS}

Although only the Bancroft region of the Grenville provinse has heen productivo of uranium to date, a number of other areas have been of sufficicnt interest to encourage extensive exploration activities. One of the principal areas is the north shore of the Gulf of St. Lawrence. Others mentioned by Ruzicka (1.079) are MacTier and Sharbul Lake In Ontario and Fort Colougne and Mt. Laurier in Quebec. Baldwin (1970) has described several of the uranium and thorium occurrences along the north 
shore of the Gulf of St. Lawrence in eastern Quebec. The main deposits are near Sept Iles, Baie Johan Beetz, Romaine and St. Augustin River (Figure 9), but many others are known to exist in the region. All of these are in pegmatitic rocks of the Grenville province.

Baie Johan Beetz

The radioactive occurrences at Baie Johan Beetz are associated chiefly with pegmatitic masses, sills, and dikes in the Lac Turgeon granite stock and to a lesser extent with a smaller granite intrusive. The uranium minerals occur in the pegmatite in erratic pods up to 100 feet in diameter and as disseminations. They are also associated with the granite itself and with granite gneiss. The white and grey pegmatites, rich in plagioclase and biotite, and the red and pink granites contain the highest concentrations of uranium and thorium. The muscovite-bearing pegmatites are always barren. Uraninite and uranothorianite have been identified and are associated with zircon, magnetite, biotite, and molybdenite. Hematitic alteration is locally associated with the uranium mineralization.

A striking feature of the Lac Turgeon granite is the abundant metasedimentary and amphibolitic material present within the granite and pegmatitic rocks (Mackle, 1977). Detailed studies (Hauseux, 1977) suggest that the Lac Turgeon granite is a granitized derivative of metasediments, and that the uranium occurring in the granite itself is related to the granitization process. The metasediments around the Lac Turgeon granite are part of the Wakeham Bay Group which consists of quartzites, schists, phyllites, marble, and aluminous bands, intercalated with sills of metagabbro. The Wakeham Bay Group has been correlated with the Grenville Supergroup because of similar age relations to the basement gneiss complex and the gabbrolc Intrusions. 
The metasedimentary rocks can be traced from the surrounding metamorphic belts well into the Lac Turgeon granite (Mackie, 1977). The latter contains numerous inclusions of metasedimentary rocks measuring up to several yards long (Hauseux, . 1977). The granite areas with these small remnants also grade into metasedimentary blocks of much larger size. Sedimentary bedding can often be traced into the granite, which is not uncommonly banded parallel to this bedding. Contacts between granite and metasediments are mostly conformable to bedding, but can also be transgressive.

According to Hauseux (1977) the uranium mineralization, which is in the form of uraniferous migmatite, metamict zircons, and uraninite, can be explained by remobilization of uranium during regional dynamothermal metamnrphism from primary uraniferous and zirconiferous sediments into granite. Flow-folding metamorphism and autometasomatism are the proposed granitization agents, with fluids having been derived from fluviatile shaly arkoses and sandstones.

The gradational contact with metamorphic rocks, passing through a zone of migmatites to a pegmatitic-migmatitic terrain and finally into predominantly granitice. and pegmatitic rock, argues against an intrusive origin (Mackie, 1977). This is reinforced by the presence of metasedimentary rclicts within the granite in an undisturbed arrangement consistent with the regional sţructure. Arrnrring to Mackie (1877); metamorphism in the area appears transitional between uppcr amphibolite facies and lower granulite facies and could have been accompanied by partial melting. He attributes the petrogenesis of the granitic and pegmatitic rocks to anatexis of the pre-existing supracrustal metasediments of the Wakeham Bay Group during high-grade regional metamorphism. Hauseux (1977), on the other hand, concludes that anatexis is inconsistent with the many conformable metasedimentary relicts found in the 
granites. An epigenetic or igneous hydrothermal source for the uranium is ruled out by both investigators.

Mackie (1977) considers the uranium to have originated from sediments and to have concentrated during metamorphism of the sediments into an anatectic melt. Further concentration took place from the melt into hydrous pegmatitic phases which accumulated in fold axes and noses.

\section{Romaine}

Uraninite and traces of uranium associated with monazite have been found in pegmatites, granites, and biotite gneiss near Romaine, Quebec. The uranium and thorium arc commonly associated with pegmatitic material injected into amphibolite. Magnetite is a common accompaniment.

St. Augustin River $r$

The St. Augustin River area is underlain by a metamorphic complex of Grenville gneisses and granites which have been intruded by dikes. Discontinuous and narrow veins of pegmatite and aplite occur through the area. The pegmatites contāin blotite, magnetite, chlờile, and minor monazitc, fluorito and pyrite. Uranium occurs on a small scale as uraninite localized along joint planes in quartz-feldspathic gneiss. The monazite is present in gneiss, migmatitic rock, and pegmatite, and is also associated with magnetite in paragneiss.

\section{GRE NVILLE PROVINCE -- IN QUEST OF A "ROSSING" DE POSIT}

The majority of pegmatite deposits worldwide occur in areas of batholithic granite emplacement in crustal mobile belts where the plutonic rocks are most likely 
generated from assimilated geosynclinal sediments. The composition, particularly the uranium-accumulating characteristics, of the geosynclinal prism may be an important factor in determining the favorability of derivative granitic rocks and related pegmatites for uranium. Metallogenic provinces are not random in their distribution. Many are characterized by a concentration of specific groups of metals, which may be much less abundant elsewhere. Since the earth's crust differs in its history, structure, and composition from place to place, it is not surprising that different parts of it are characterized by different suites of ores. This applies also to uranium.

Robertson and Lattanzi (1974), for example, have speculated that the relatively high uranium content of the Bancroft area deposits might be due to rejuvenation of uranium (and rock) from pre-existing detrital deposits of Aphebian age which were re-worked during the Grenville event. McMillan (1977) has concluded that metamorphism has affected many Precambrian deposits in Canada, particularly those in the Aphebian fold belts, with resultant formation of uraninite from pitchblende, and that the quantitative development of pegmatites is enhanced by increasing metamorphic rank. Bancroft is suggested as an example of almost complete partitioning of uranium into metamorphically-derived pegmatites from shelf-facies metasedimentary rooks.

The implication, of course, is that uraniferous pegmatite deposits are most apt to occur where uranium had previously been chemically or physically enriched in earlier rocks. Actual recognition of an earlier favorable terrain would certalnly enhance the search for uranium by focusing attention on specific lithologic or tectonic regions suitable for early Proterozoic uranium enrichment. This is easier said than done. In fact, references to a predecessor, later reworked, uranium-enriched lithology usually fail to identify, except in the most inexact or vague terms, the type of occurrence or geologic characteristics of the region that was earlier favorably 
endowed. Bancroft and Baie Johan Beetz are examples of this. Nevertheless, the general idea is a worthy one, if in fact difficult to pursue.

On the other hand, geologic analogy or comparability seems much more useful. French geologists admit, for example, that their interest in and persistence in exploring Niger was encouraged by the resemblance of the Arlit region to the uraniumbearing areas of the Colorado Plateau. Hence, they used the Plateau as their model. This, too, coupled with the many pegmatite occurrences uncovered there is undoubtedly the basis for renewed interest over the past few years in the Grenville province of Canada. The model evidently being used there is based on the geology and geological and genetic interpretation of the Rossing deposit of South West Africa.

The search for Rossing-type uranium deposits is being conducted in the Canadian Shield in several areas including the Grenville province (McMillan, 1977). Even though much of the exploration and the discoveries in the St. Lawrence pegmatite belt in this region preceded by many years the announcement of the importance of Rossing as a uranium source, it is obvious that the possibility of a Rossing-type deposit existing in the belt has given motivation for renewed interest in the region. This is emphasized by Mackie (1977) who has stated that interest in low-grade uranium deposits in granitic and pegmatitic rocks was intensified following the discovery of the Rossing deposit, and that known potential areas for such deposits in Canada include the Baie Johan Beetz area of Quebec. This motivation also seems to prevail in studies of low-grade uranium potential in granitic and anatectic rocks of the Grenville province by the Geologioal Survey of Canada (Ruzicka, 1977).

Adams, Arengi, and Parrish (1980) make a distinction between non-anatectic and anatectic pegmatites and between pegmatites of true igneous origin and metamorphic 
origin. The Rossing deposit is classified by them as an anatectic pegmatite of metamorphic origin. Igneous non-anatectic pegmatites are considered to have been derived from a magma by differentiation. The metamorphic pegmatites are thought to have involved recrystallization or diffusion resulting in pegmatite formation via metasomatism or related processes. Many of the more important pegmatites are thought to be, in part, metamorphic. The Bancroft pegmatites are placed in this category, having, according to popular opinion based on field relationships, evolved by both intrusion and replacement. Many of these ideas or conclusions are of course hypothetical, but they provide useful working concepts. For example, if the Bancroft pegmatites were derived in whole or in part from the Grenville Group supracrustal rocks they intrude and metasomatically or otherwise replace, then consideration must be given to the composition and other properties of the supracrustal rocks as a factor in uranium emplacement. If, on the other hand, these pegmatites and their uranium are chiefly the result of metamorphic assimilation of older basement rock and mobilization of the resulting granitic material into the Grenville Group, then the uranium source must be sought outside of the Grenville metasediments, cven though, as pointed out by Hewitt (1957), these rocks do provide the chemically conducive environments for pegmatite emplacement and uranium concentration. In either case, the Grenville Group metasediments should be considered an important medium for pegmatite formation and uranium precipitation. Because the only significantly productive (of uranium) pegmatites in North America are associated with Grenville Group metasediments which extend southward into the Adirondack Lowland, the search for similar deposits in the northeastern United States could advantageously stress localities within the Lowland and the synforms or basins of Lowland lithology in the Adir ondack Highland region. Hence, the Adirondack Lowland warrants as much 
attention as the Highland region which was preferentially suggested by Adams, Arengi, and Parrish (1980). It is of interest to note, in this regard, that about one third of the pegmatite localities identified by these investigators in the Adirondack Mountains are located within the Lowland or in outliers of Lowland lithology.

The search for Rossing-type deposits in the Grenville area of Canada has, as previously mentioned, evidently been stimulated by the association of large resources of uranium with granitic (alaskitic and pegmatitic) rocks cutting gneisses, marbles, metapelites and conglomerates near Swakopmund in South West Africa. Grenville lerrain has many oimilarities to the favorable Rossing area, and it is likely, therefore, that previously held views on pegmatite genesis in the Grenville province have been and are being re-examined, and possibly modified or discarded, in favor of models that simulate and may improve prospects of discovering Rossing-type deposits in the region.

\section{ROSSING DEPOSIT}

The predominant uranium mineralization at Rossing is associated with fine-tocoarse-grained alaskitic granite and pegmatite in a migmatite zone that shows concordant, discordant, Intrusive, and replacement relationships to the folded gneisses, schists, and marbles in which the alaskite is emplaced (Berning, et al, 1976). The deposit lies in a late Precambrian northeasterly trending orogenic belt in an interval of moderate- to high-rank metasediments consisting of biotite-amphibole schists and pyroxene-hornblende gneiss (Khan Formation); marbles, conglomerate, and biotitecordierite gneiss (Rossing Formation); and quartzites and gneisses (Etusis Formation). The sediments antecedent to these host rocks evidently consisted of coarse-grained to 
sandy, shaly and calcareous beds as well as volcanics. Various types of granitic rocks were emplaced in these formations during the Damaran orogeny about $510 \mathrm{~m} . \mathrm{y}$. ago.

The alaskite has invaded much of the biotite gneiss of the Etusis Formation on a massive scale. It is also emplaced in pyroxene-hornblende gneiss of the stratigraphically younger Khan Formation in countless veins and dikes. The still younger Rossing Formation, which contains graphitic and pyritic marbles and pyritic schists and quartzites, shows prevalent migmatization along bedding planes and alaskite emplacement.

The sedimentary bistory of the region involves deposition of shallow-water clastics, siltstones, graywackes, and marls. These were subsequently metamorphnsed to biotitic, pyroxene-hornblende, and pyroxene-garnet gneisses. The rocks reflect both dynamothermal and contact metamorphism, the former manifested by devclopment of high-level metamorphism facies and the latter by skarns and hornfelses in the marbles adjoining the alaskitic intrusives. The skarns are associated with the final stages of crystallization of the alaskites. They are fairly small and sporadic.

The uranium-bearing rock has been called pegmatite, potash granite, and alaskite by various investigators. The alaskite is widespread beyond thc limits of the ore body and for the most part barren or sparsely mineralized. The Etusis, Khan, and Rossing Formations all contain alaskite. Where banding or herding of metasediments is well developed, alaskite tends to conform; where it is less developed, the alaskite assumes a more massive habit. Alaskite also conforms to the structure of the folded metasediments, being commonly emplaced along axial planes. 
Xenoliths of metasedimentary rock occur completely engulfed in the massive alaskite bodies, but remain conformable with the metasedimentary fabric adjacent to the alaskites. Ghost layering in the alaskite is also in line with the metamorphic grain. This indicates that the alaskite was emplaced by a passive metasomatic processs. Berning, et al (1976) suggest that the alaskite was derived at considerable depth where anatexis was active, probably from components of the Etusis and still older early Precambrian Abbabis Formations which underly the alaskite-bearing host rocks. Pronounced temperature differences seem to have existed between the alaskite and wall rock, as indicated by the contact metamorphism. They further speculate that granitizing fluids saturated and replaced already migmatized country rock by penetrating shears, fractures, joints, bedding planes, axial planes of folds and foliation planes. Dikes were progressively widened as the replacement process proceeded, eventually resulting in large irregular masses that still display metasedimentary structures. Much of the evidence also suggests that the alaskites have not moved far from their point of origin and thus were of local anatectic derivation.

The uranium itself is believed to have originated from early Precambrian basement rocks which provided sedimentary material to the Etusis Formation. These source rocks, together with the uranium, were subjected to anatexis in the core of the Damaran geosyncline.

The bulk of the uranium making up the Rossing deposit is in alaskite that is emplaced in the pyroxene-garnet gneiss unit and the amphibole-biotite schist/marble/ cordierite-biotite gneiss unit. All the primary and most of the secondary uranium is found in the alaskite. Uraninite, the dominant primary uranium mineral, is preferentially associated with biotite and zircon. It is thorium-bearing (U:Th about $10: 1$ ) and is commonly accompanied by monazite. Betafite is also present in the alaskite 
to the extent that its uranium content constitutes a minor portion of the uranium ore. Zircon, apatite, and sphene are found along with various iron, copper, molybdenum, and arsenic sulfides and fluorite. Beta-uranophane is the most abundant secondary mineral. It is present in both alaskite and country rock. Uraninite contains about $55 \%$ of the uranium, betafite less than $5 \%$, and secondary minerals about $40 \%$. Concentration of the primary uranium, particularly the uraninite, is theorized to result from reduction of $U^{+6}$ to $U^{+4}$ in areas where $E h$ was lowered and pH raised (thereby reducing the solubility of uranium) following assimilation of the country rock.

Of possible use for exploration purposes is the observation that mineralized alaskites tend generally, but not always, to be reddish to buff-colored on weathered surfaces, whereas unmineralized bodies are normally white to very pale pink (Jacob, 1974 a). The intensity of the reddish or buff coloration increases with degree of mineralization. Also noteworthy is the fact that the mineralized migmatite, alaskite, or pegmatite are spread over a wide area of many kilometers. In many of the uranium occurrences the uranium minerals are associated with magnetite, and in many instances biotite-schist xenoliths in mineralized alaøkite are emriched in uranium near their contacts relative to the alaskites possibly due to the chemically reactive effect of these iron-bearing rocks. What this indicates, as at Bancroft, is that a very widespread, intense alteration or intrusion of metasediments by anatexis-derived, migmatitic, metasomatic, plutonic or other mineralizing fluids or melts may be required to produce uranium minoralization in quantity or grade to suffice for economic recovery. The importance of magnetite and other iron-bearing minerals is also re-emphasized since these minerals arc apparently factors in uranium emplacement at Bancroft and Baie Johan Beetz. 
Perhaps genetically important is the fact that the Etusis Formation, which is one of the indicated parent rocks for the anatexis-derived uraniferous alaskite, contains quartzofeldspathic members that are possibly of volcanic origin. Acid volcanic rocks have been reported from the Etusis Formation but are not recognized everywhere in the Damara: belt (Jacob, 1974 b). The mineralized alaskites are, interestingly, confined to the western part of the central Damara. belt where metavolcanic rocks are most prominently developed. The Nosib and Damara rocks, which include the Etusis, Khan and Rossing Formations, have been subjected regionally to high-grade dynamothermal metamorphism producing mineral assemblages of the amphibolite facies and grading westwardly in the belt to a higher stage metamorphism. This metamorphism undoubtedly affected the volcanics as well as the more conventional sediments and produced changes in them. The significance of the volcanics in the Rossing area can only be inferred at this time. It is suggested here, and will be re-emphasized later on the basis of studies of the Adirondack Mountains, where alaskites are presumably the product of metamorphism of volcanics, that volcanic rocks could very readily have been altered to and may account for much of the alaskite at Rossing. The volcanics conceivably could also have been the source of the uranium.

Of possible equal importance is the fact that the original sediments of the Damara rocks overlying the Nosib Group contained carbonaceous reducing environments that are now chiefly manifest in the graphitic nature of the schists and marbles. Some of these metasediments are still fetid. Disseminated sulfide, mainly pyrite and pyrrhotite, characterize the Rossing Formation which is commonly stained by iron oxides. Copper sulfide mineralization, probably related to reducing conditions in the pre-existing sediments is widespread in the Khan Formation. Jacob (1974 a) has proposed that sulfides in the host-rock formations were decomposed during metamorphism and released 
sulphur that precipitated uranium. This process, together with the $\mathrm{Fe}^{2+} \rightarrow \mathrm{Fe}^{3+}$ and $U^{6+} \rightarrow U^{4+}$ reaction which would have involved biotite-rich and other iron-bearing host-rock minerals conceivably brought about most, if not all, of the precipitation of uraninite in the alaskite.

Reductants, including graphite which is the residual end product of metamorphism of organic matter, have been noted in the host metasediments at both the Rossing and Bancroft deposits and are possibly also implicated in uranium deposition at Baie Johan Beetz. Whether the host-rock reductants are fortuitously present (but uninvolved) simply because they are such a universal part of the general sedimentary and derivative metamorphic environment, or whether they actually played a role in the formation of pegmatitic, granitic, and alaskitic uranium deposits is debatable. Their usefulness in modeling or concept development is not to be diminished, however, in view of the fact that reduction is in fact a viable means of bringing about uranium deposition. Reduction is a very well known and accepted factor in uranium-oxide precipitation under low-temperature conditions, and it should also be effective at higher temperatures and pressurcs.

Very useful mndels, involving reduclion havè becn developed for uranium precipitation in economic deposits in sandstonc, limestone, and shale environments. Equally useful models can be applied to formation of unconformity-related deposits that may extend the range of favorability far beyond the geologic environments in which these deposits are now identified. The foregoing perceptions of Bancroft and Rossing strongly suggest that the reducing nature of the host rocks must be considered. a possible instrument of uranium deposition under metamorphic and/or igneous conditions in the formation of pegmatitic and alaskitic uranium deposits. A volcanogeneticreduzate accretion model provides a working concept that encourages the examination 
of otherwise unsuspected or unattractive areas from a fresh viewpoint for Rossingtype and pegmatite-type deposits. The search for additional "Rossings" should, therefore, be undertaken with the above facts, observations, suggestions, and ideas in mind. The extent of their possible applicability to the lithologies of the northeastern United States, particularly to the Adirondack Mountains, will be discussed in a following section.

\section{URANIUM DEPOSITS IN APHE BIAN METASEDIMENTS, LABRADOR}

The geologic setting and genetic aspects of uranium occurrences in the Kaipokok Bay-Big River area, Labrador, are of interest because generally similar geological environments are indicated in the lithologies of both the Adirondack Lowland and the Paleozoic metasediments of the New England Appalachians. The deposits, described by Gandhi (1978), fall into two groups represented by the Kitts and Michelin deposits, both of which are associated with acid metavolcanics and metasediments of marine origin.

The Kaipokok Bay-Big River area lies within the Nain structural province of the Canadian Shield a few miles to the north of the Grenville front in the vicinity of Makkovik on the east coast of Labrador (Figure 10). The area contains Archean migmatized gneisses rich in granite and pegmatite, but is principally underlain by Aphebian paragneiss, migmatite, granulite, and granite gneiss intruded by syntectonic (Hudsonian orogeny, 1,700 m.y.) granodiorite, post-tectonic granites and also gabbro, diorite, and syenite. No effects of the Grenville orogeny are observed in the immediate area. 


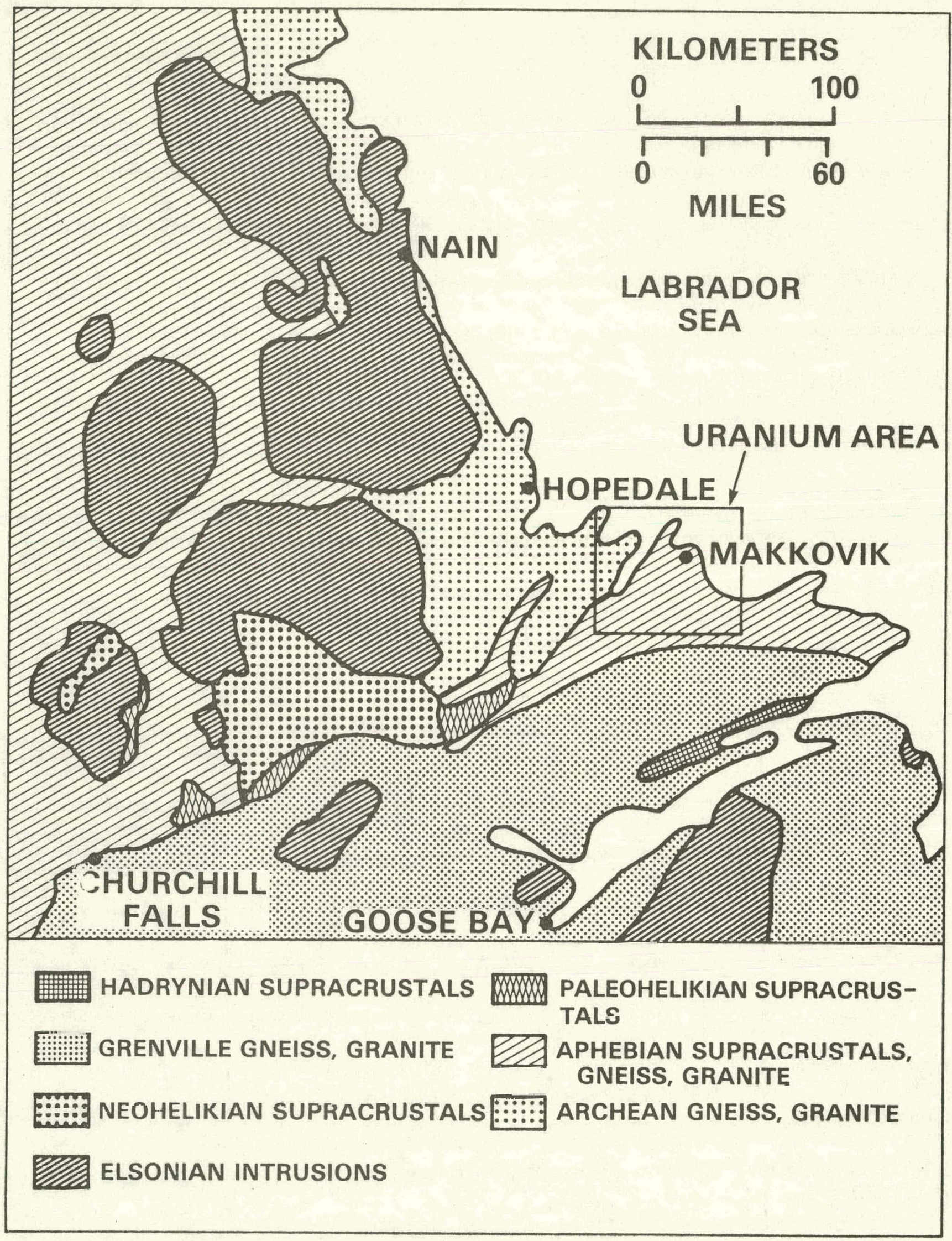

Figure 10. Kaipokok Bay-Big River uranium area setting, Labrador (after Gandhi, 1978). 
The rocks of the uranium-bearing Aphebian Aillik Group comprise paragneiss and paraschist; metabasaltic lava and mafic metatuff; metasiltstone metaconglomerate, with minor quartzite, metachert, and metaargillite; metarhyolite and felsic metatuff; metavolcaniclastic breccia; and porphyry and porphyritic gneiss. The degree of regional metamorphism is in the range of upper greenschist to amphibolite facies. The metamorphosed conglomerate and siltstone are widely distributed. The siltstone is gray to dark gray with green and pink layers suggesting mafic and felsic tuffaceous layers. Thin beds of laminated metamorphosed tuff, chert, and argillite are present at the base of the siltstone. The conglomerate is in places associated with rhyolitic volcanics which attain a thickness of up to 700 meters. The metamorphic effect on the volcanics has produced essentially quartzofeldspathic gneisses and schists. The argillaceous beds and basaltic flows are assumed to have been deposited under relatively deep-water marine conditions, and the siltstones and conglomerates under shallow-water conditions. Acid volcanism, which is probably largely subaerial, and sedimentation are considered to have been to some extent contemporaneous. The metasediments are folded into broad open anticlines by syntectonic gneiss domes. Folding is tight in some areas. The sediments and volcanics are not considered to be geosynclinal accumulations but presumably constitute intra-cratonic basin dèposits affected by orogenic deformation, metamorphism, and intrusion during late Aphebian time. The present exposures are believed to represent the upper zone of the orogen.

\section{Kitts Deposit}

In the Kitts area, the uranium occurrences are in metamorphosed argillite which is interbedded with metamorphosed chert and basaltic flows. The argillite 
is andalusite- and garnet-bearing. The matrix is albite, quartz, amphibole, and biotite, with minor pyrrhotite. The composition reflects an average shale with relatively high iron content. Dark gray, graphitic, pyrrhotite-bearing beds ànd lenses form only a minor part of the argillite but contain most of the uranium mineralization which is concentrated in thin beds and laminae in stratiform zones up to 10 meters wide and 300 meters long. Veins and shears of uranium, which is present as pitchblende, also occur in the argillite and extend into the adjacent chert and flow rocks. The pitchblende contains only traces of thurlum and is generally disseminated or forms string-like aggregates along the beds. Graphite is present in concentrations of 1 to 2.5 percent, and pyrrhotite up to 10 percent, occasionally forming thin beds or lenses up to $5 \mathrm{~mm}$. thick. Sulfide also occurs in veinlets intruding the country rock especially where folding of the pyrrhotite stringers is tight. Calcite is also found as veinlets. Pink calcite appears to be associated with the mineralization. Magnetite is locally concentrated in the argillite.

Smaller uranium deposits occur peripheral to the Kitts area in similar stratiform settings but of more varied lithology. A number of . these dejusits are associated with laminated tuff interbedded with gray and pink siltstone. The tuffs have a reddish appearance where the uranium content is relativcly high. Depusits are also found in siltslune that is interbedded with tuff beds.

\section{Michelin Deposit.}

The Michelin deposit occurs in an area where uranium deposits are widely distributed in metamorphosed rhyolitic rocks. The major occurrences are within an area $1 \mathrm{~km}$ wide and $15 \mathrm{~km}$ long. The Michelin deposit, itself, occurs within a stratigraphic interval about 40 meters thick and over a strike length of more than 1,000 meters. The host rock sequence consists of alternating feldspathic porphyritic and 
subporphyritic rhyolites containing a few thin tuffaceous lenses. The uranium mineralization occurs finely disseminated in lenticular zones up to 5 meters thick and several hundred meters along strike chiefly within the porphyritic rhyolite.

The rhyolites are cut by premetamorphic dikes, some of which contain minor amounts of uranium. Postmetamorphic dikes are also present but contain no recognizeable mineralization. Those that are mineralized consist of albite, amphibole, biotite, and calcite.

The rhyolitic host rocks are alkaline with variable degrees of $\mathrm{Na}_{2} \mathrm{O}$ and $\mathrm{K}_{2} \mathrm{O}$ enrichment. Those with extreme enrichment in one alkali and depletion in the other apparently have undergone alkali metasomatism. The uranium mineralization occurs within the rhyolites enriched in $\mathrm{Na}_{2} \mathrm{O}$ but not all such rocks contain significant mineralization. The petrographic character of the mineralized rhyolites is generally similar to that of the unmineralized texturally-equivalent rocks except for uranium content, the presence of hematite, and the nature of the feldspar and other silicates present.

Feldspar in the mineralized rock is essentially all albite, whereas unmineralized rocks contain both albite and potash feldspar. The albite reflects soda metasomatism. The pyroxene (aegirine) and amphibole in the mineralized rock also are sodic.

The uranium mineralization is finely disseminated in the rhyolite. It is accompanied often but not invariably by red coloration, which persists in the unweathered rocks, due to hematite. The: red color of mineralized rock contrasts with the normally light gray and pale pink to cream color of unmineralized rhyolite. The uranium host mineral is sphene which contains finely included pitchblende that is evidently lacking in thorium. The sphene is metamict and contains inclusions of magnetite and what 
appears to be apatite.

Several similar uranium deposits occur in the area around the Michelin deposit. Some of these are in rocks other than rhyolite; e.g. tuffaceous calc-silicate skarnlike rocks, quartz feldspar porphyry, and argillite-tuff inclusions in granite and granite gneiss.

\section{Cape Makkovik-Monkey Hill Belt Deposits}

The uranium deposits in this region arc also in metamorphosed rhyolitic rocks showing evidence of soda enrichment. However, the geologic setting exhibits features that are not prevalent in the Michelin deposit area and is, therefore, of additional interest here.

Some of the rhyolitic hosts in this region are notably magnetic due to finely dispersed magnetite grains which impart a gray color to the rocks. Purple fluorite is also widely distributed, mainly in streaks; and pyrite, molybdenite, and minor gulend and sphalerite are present in some of the occurrences.

The uranium occurs in pitchblende in slxeaks parallel to foliation. The host rhyolites in some places overlie agglomerate, conglomerate, quartzite, and siltstone; and may contain tuffaceous beds.

Although the association of pitchblende with pyrite and molybdenum is very uncommon in the area, molybdenite deposits essentially free of uranium are found elsewhere nearby, A large molybdenite-pyrite dcposit occurs over a length of 2,500 meters in rhyolite enriched in $\mathrm{Na}_{2} \mathrm{O}$ and depleted in $\mathrm{K}_{2} \mathrm{O}$. The uranium and molybdenum mineralizations are believed to be contemporaneous and predate the regional metamorphism of the Hudsonian orogeny. 


\section{Genetic Aspects}

The uranium mineralization at the Kitts deposit is indicated by $\mathrm{U}-\mathrm{Pb}$ age determinations to be older than the Hudsonian orogenic events. Similar studies on the Michelin deposit, on the other hand, suggest that the uranium is considerably younger than the Hudsonian orogeny. However, in the latter case the ages are believed to have been affected by postmineralization intrusions and may not represent the primary mineralization at this occurrence.

Gandhi (1978) has summarized the significant features of the deposits in the Kaipokok Bay-Big River area and has derived a number of conclusions regarding their genesis. The dominant stratigraphic control manifested by the Kitts deposits indicates a syngenetic sedimentary origin. Subsequent geologic events have locally redistributed the uranium into veins, shears, etc. but have not obliterated the original mineralization in the host-rock beds. The uranium was deposited under reducing conditions in a black shale containing pyrite and carbonaceoús matter (now present as pyrrhotite and graphite) which localized the uranium concentrations. The bedded chert underlying the mineralized argillite is believed to have originated from a volcanic source and precipitated under reducing conditions. The setting is one of a relatively deep marine basin with restricted circulation. Marly beds, laminated tuffs, and siltstones containing an abundance of material derived from acid volcanics and tuffs are encountered regionally. This, together with the existence of rhyolitic volcanics to the south and east, suggests a volcanic source för the urauiuin as wcll ao Eome of the sediments.

The main features and wide distribution of the Michelin deposit indicate that the mineralization process was operative over a large area and was probably associated with a volcanogenic fluid phase enriched in sodium, uranium, and volatiles that 
permeated through parts of the rhyolite sequence. The uranium was extracted from the mineralizing fluid by reaction with titanium in the sphene which is a common accessory in the rhyolites. Later metamorphism resulted in recrystallization of the sphene and formation of pitchblende. The concentrations of molybdenite, pyrite, and fluorite elsewhere in the rhyolite suggest that the constitutive elements were also concentrated in the volcanic fluids and deposited locally under favorable conditions.

\section{PENA BLANCA URANIUM DEPOSITS, CHIHUAIIUA, MEXICU}

Although little is known concerning the geology of the Pena Blanca region In Mexico, the information that is available on the uranium setting is sufficient to formulate a genetic model of interest here because of its possible application, despite the differences in age, to the geologic terrain in the Adirondack and Appalachian regions.

The Pena Blanca uranium district has been described by Goodell, et al (1978). It is situated $50 \mathrm{~km}$ north-northeast of Chihuahua, Mexico, in a region of basins and ranses containing Cenozoic and Mesozoic rocks. The features of chief significance are (1) economic uranium mineralization in volcunle rocks, and (2) underlying limestones upon which the volcanics were deposited.

The Pena Blanca region lies within a depositinnal basin containing Mesozoic sediments, including limestones, that were extcnsively folded and faulted. These rocks were exhumed and partially eroded during early Tertiary time with formation of limestone conglomerates on a regional scale. This environinent was overlain by widespread caldera-related ash-flow tuffs and local basalt and rhyolite flows. Andesitic stratovolcanoes, composed of alternating layers of lavas and pyroclastics and related intrusions, are also locally present. 
The volcanic rocks in the areas surrounding the Pena Blanca district range compositionally from calc-alkaline to alkaline. The Cretaceous limestones peripheral to the district contain numerous stratabound and vein deposits of galena and sphalerite, particularly in the Santa Eulalia area $30 \mathrm{~km}$ east of Chihuahua city, where the carbonates are capped unconformably by ash-flow tuff units. There are resemblances here to the lithology of the Pena Blanca area, and uranium occurrences have been reported in welded tuffs.

In the Pena Blanca mining district the Cenozoic volcanic pile lies on massive Lower Cretaceous limestones containing reef-like mounds that are common near the mineralized zone. Some 200 meters of limestone conglomerate, and welded, unwelded, and fragmental tuffs make up the dominant lithologic sequence. The Cretaceous fossiliferous (rudistid) reef complex was apparently being exhumed with the formation of thick local limestone conglomerates prior to deposition of welded tuffs (Nopal Formation). The mineralized volcanics are underlain by the carbonate reef. They constitute distal caldera-related facies. No intrusive rocks crop out within or near the mining district.

Uranium occurs in several different environments in the Pena Blanca district, with several frequently i'epresentcd in the same occurrence. Joints and faults, and breccia zones in welded volcanic members, are mineralized resulting in small high-grade deposits. Porous and permeable volcanic units are mineralized to form stratabuuind deposito, Altered vitrnphyre at the base of welded tuff also provides more permeability for mineralization than the surrounding ronk, as does porous pumice. The underlying Cretaceous limestone contains uranium along faults and in solution cavities beneath the volcanic units. In all, permeability seems to play an important role in uranium distribution. 
Uraninite (most likely pitchblende) is found in breccia zones together with uranophane, Molybdenum accompanies it. Uranium and molybdenum also occur in stratabound deposits (Margaritas area) in altered vitrophyre and/or pumice. All of the uranium is hexavalent and is accompanied by widespread hematitization adjoining the deposit. The stratabound uranium lies adjacent to a prominently fossiliferous reef in underlying limestone which, according to Goodell, et all (1978), is suggestive of a paleohydrological influence of the reef on mineralizing fluids.

Al Sierra Gomez, $15 \mathrm{~km}$ east of Pena Blanca, hexavalent uranium mineralization also occurs in faults and solution cavities in the limestone, with fluorite.

Rock alteration is intimately associated with the uranium deposits and becomes more intense closer to major deposits. The alteration is suggested by Goodcll, el al (1978) as a useful criterion for exploration for uranium deposits in volcanlc rocks elsewhere. The alteration appears as a bleaching from the normal red color of the host rock to white and has been related by statistical treatment of chemical analytiral data to alkali (potassium) depletion and silica enrichment. This is of significance in light of the observation at Michelin, Labrador, as noted earlier, that the uranium mineralization there usually occurs within rhyolites enriched in $\mathrm{Na}_{2} \mathrm{O}$ and depleted in $\mathrm{K}_{2} \mathrm{O}$. This suggests the possibility of alkali metasomatism at Pena Blanca as a factor contributing to uranium mineralization.

The genesis of the Pena Blanca deposits is not known--howcver a number of ldeas have beeil advanced (Goodell, et al, 1978). A magmatic-hydrothermal model was considered but rejected, because of the absence of nearby intrusives, in favor of more attractive-hyputheses. A near-caldera magmatic source was also discarded because of the distal nature of the volcanic facies. Several alternative sources of the uranium have been suggested which include (1) high-grade veins in the vicinity, 
(2) glass in the volcanic pile, and (3) deeply buried connate waters, with source (2) being considered the most likely. Transportation of the uranium is attributed to ground and surface waters, or diagenetic water, and possibly hydrothermal-connate water heated by caldera-related or intrusive activity. Depositional control may include silicification, associated with alteration, which would account for the abundance of uranophane and also uraniferous chalcedony. However, it is questionable whether this process, or more recent ground-water activity, contributed chiefly to uranophane formation.

The presence of marcasite and uraninite at several localities in the district is recognized (Goodell, et al, 1978) as indicative of precipitation of at least some of the uranium under reducing conditions. This has, however, been questioned because of the absence of organic debris in the Pena Blanca deposits. Neutralization from a basic condition is offered as an alternative explanation. All of these mechanisms, including alteration, have been attributed to reaction zones existing at the interface between ground water in volcanic terrain and ground water in limestone.

This writer:feels that these deposits can be explained more logically by the reducing reaction of $\mathrm{H}_{2} \mathrm{~S}$ derived by bacterial activity (sulfate-reduction) in the reef environments that contained the organic residues from the decaying inhabiting organisms (rudistids). The galena and sphalerite deposits in limestones in the Santa Eulalia area and the marcasite content of Pena Blanca uranium deposits indicate the availability of sulfide sulfur in both limestones and volcanics. The porous reef structures and adjacent volcanica provide permeability for $\mathrm{H}_{2} \mathrm{~S}$ migration from the limestone into mineralizing sites in the volcanies and also allow the passage of uraniumbearing fluids in both rocks. Bleaching of the normally reddish volcanics can also be attributed to the reducing action of $\mathrm{H}_{2} \mathrm{~S}$ on hematite and is a highly visible indication 
of the mineralizing potential of the host rocks.

Reef or other carbonaceous limestones, as well as pyritic, carbonaceous shales and siltstones extensively provide chemical environments conducive to reduction and deposition of uranium and other metals. Adjacent or nearby felsic volcanics are a source of uranium that may be syngenetically or epigenetically deposited in either the carbonaceous sediments or the volcanics. The Pena Blanca, Kitts, and Michelin occurrences are examples of uranium mineralization in geochemically favorable environments, associated with carbonate. and argillaoooug sedimenls, respectively. Their geologic settings, therefore, provide a conceptual basis for comparison with the Adirondack and Appalachian regions which contain rocks manifesting equivalent environments, i.e. pyrrhotite-pyrite- and graphite-bearing marbles, meta-argillites, schists, and gneisses, as well as metamorphosed, recrystallized volcanics.

\section{ADIRONDACK MOUNTAINS REGION}

The Adirondack Mountains are a southeasterly extension of the Grenville province of the Canadian Shield into New York State. The massif consists of (1) high $=$ grade unelamorphosed rocks that possess relict igneous textures and (2) enclosing metamorphic rocks of sedimentary, volcanic, and uncertain origin. The rocks have been affccted by the Grenville geotectonic orogeny at about $900 \mathrm{~m} \cdot \mathrm{y}$. ago but have remained essentially undisturbed since then.

The northwestern part of the Adirondnaks is a piedmunt-like area of gentle relief known as the Adirondack or Northwest Lowland. The eastern sector is an area of greater relief known as the Adirondack Highland or Central Highland. The boundary between them is marked by a major shear zone. The two subdivisions are largely bedrock-controlled. The Northwest Lowland is composed almost entirely of 
metasedimentary rocks that are poorly resistant to erosion, whereas the Central Highland consists of more resistant rock types, primarily granitic and syenitic gneisses and highly resistant anorthosite. The Central Highland is obviously the igneous-rich sector of the massif. Patches of subordinate metasedimentary rocks are distributed locally in the Central.Highland valleys. These are erosional remnants of Northwest Lowland lithologies downfolded and preserved in basins or synforms.

The metasedimentary rocks of the Adirondacks are marble, calc-silicate rocks, quartzite, and paragneisses originating from limestones, siliceous limestones, sandstones, and shales deposited in a shallow marine environment. They account for about 80 percent of the bedrock in the Northwest Lowland and persist as scattered remnants within the downwarps in the Central Highland. These rocks have been correlated with the Grenville Group metasediments of the Grenville province in Canada.

\section{GEOLOGY OF THE ADIRONDACK I.OWLAND}

The Grenville Group in the Northwest Lowland have been described by Engel and Engel (1953 a) and more locally in subordinate outliers in the Central Highland by Leonard and Buddington (1964) on whose accounts the following data are based. The expused Grenville Group is estimated to be at least. 15,000 feet in the Northwest Lowland and to have approached 20,000 feet before metamorphism. No break in the sequence is recognized.

The major belt of mnrhle in the Grenville Group occurs in the southwestern part of the Grenville province extending from Canada southward into the Adirondacks; Vermont, New Jersey, and southeastern Pennsylvania. In the northwest Adirondacks there are three thick marble zones that aggregate at least 8,000 feet thick, and many thinner zones. The associated clastics account for about another 8,000 feet of the 
metasedimentary sequence. Fach marble belt can be traced along strike for about 35 miles and is probably correlative for nearly 100 miles to the north in Canada. The marble thins considerably toward the southeast in the Adirondacks (Paradox Lake and Ticonderoga quadrangles) where the exposures in outlying Grenville Group metasediments measure less than 750 feet thick. Several marble zones appear in the Precambrian sequence of northwestern New Jersey and southeastern Pennsylvania, which resembles the Grenville Group of the Adirondacks. In New Jersey, the Franklin Limestone is estimated to exceed one-half mile in thirkness.

The marbles of the Grenville Group show appreciable variation in magnesia content. Throughout much of the northwest Adirondacks the dolomitic areas of marble weather gray, whereas the calcitic areas weather white, but this is not a consistent characteristic everywhere throughout the Grenville Group. In this region, many of the oldest carbonates are dolomitic. Within these carbonates are large zones of calcitic marble formed by extraction of magnesia during metamorphism, the latter having been moved over appreciabledistances and refixed in masses of tremolite, anthophyllite, serpentine, and talc, some of which have been mined.

Graphite has been reported in marble almost everywhere that detailed studies have been made. Fetid or $\mathrm{H}_{2} \mathrm{~S}$-bearing marbles have been reported in both Canada and the nor thwest Adirondack Mountains. Pyrite is also apparently widespread. In the Adirondacks, $\mathrm{H}_{2} \mathrm{~S}$-bearing layers form concordant zones in the marbles and are closely associated with anhydrite, gypsum, and natural gas. The naturul guas is reported in marble at depths of as much as 2,000 feet near Edwards and Balmat, and contains methane, ethane, and nitrogen. The anhydrite, and gypsum, are interstratified in the marble as sedimentary interbeds. They have been noted also in the northeastern Adirondacks and Canada at widely separated localities invariably 
in association with sulfide-bearing ore deposits.

Graphite has been reported also by Hewitt (1957) in mineable quantitities

(World War I) in Grenville Group marble, feldspathic paragneiss, and amphibolite in many places in the Bancroft-Halliburton area of Ontario. It occurs in many deposits as disseminated flakes and in bands. In one locality, graphite is accompanied in paragneiss by adjacent bands of disseminated pyrrhotite and molybdenite which occur in rusty-weathering streaks. In some mining prospects near Bancroft the marble. contains up to 2-3 percent flake graphite. Drilling in 1951 revealed a graphite-bearing zone 1,200 feet long and 60 feet thick containing an orebody of $1,440,000$ tons grading 4. 1 percent carbon in limy paragneiss.

Paragneisses consisting chiefly of quartz and feldspar and containing either appreciable sillimanite and garnet, or biotite, are pervasive throughout the Grenville Group in the Adirondacks and rank second to the marbles in abundance. The largest gneissic unit in the Adirondacks is about 3,000 feet thick. The paragneisses commonly contain graphitic segments. The chemical composition of the gneisses is approximately that of typical graywacke, tuff, or average shales.

Quartzites are present in the Grenville Group on the northwest and southeast sides of the Northwest Lowland in massive zones as much as 50 to 200 feet thick. Generally, however, they appear as narrow interbeds and zones in many parts of the Grenville Group. Both pyritic and graphitic types are known. Some in the Adirondacks are feldspathic and were presumably derived from arkosic parent sediments.

Amphibolites are widespread in the Grenville Group, most being largely hornblende and andesine. Their origin has been the subject of much debate and speculation. Some investigators have suggested that they evolved as metasomatic replacements of marble, particularly where granite intrusives are evident. Others suggested evolution 
through dynamothermal metamorphism of intrusive gabbros. Some amphibolites are known or inferred to have formed by reconstitution of lava flows and tuffs interlayered with the Grenville Group, or by reconstitution of argillaceous dolomite layers.

All of the Grenville Group environments in the Adirondacks appear to have been marine. The carbonates apparently were deposited in a relatively stable basin, perhaps periodically closed off from the open ocean, that extended from Canada to western Vermont and southward into New Jersey.

Volcanics are clearly identifiable in or closely assnciated with the Grenville: Group only in southeastern Ontario. Elsewhere, amphibolitic rocks of obscure origin may have evolved in part from flows or tuffs. In Canada, basic volcanics, agglomerate, and tuff lie at the base of the Grenville Group and are perhaps interbedded with it as already mentioned. There is some opinion that volcanics occur also at or near the top of the Grenville Group. The major paragneiss of the Northwest Lowland is thought to possibly have originated from tuffaceous material, but Engel and Engel $(1953 \mathrm{~b})$ ofter arguments to dispute this interpretation. Alaskites, thought earlier to represent phacolithic facies of granites (Buddington and Leonard, 1962) have more recently (C'àl and Van Diver, 1975) been re-interpreted as a wide-ranging sequence of volcanic tuffs. These rocks will be discussed in more detail subsequently.

Within the Nülliwesl Luwland, Precambrian metasediments of the Grenville Group predominate over Precambrian igneous rocks and are far less modified physically and chemically than thrnuphout most of the igneous-rich roginn of the Central Highland. But even in the Northwest.Lowland mixtures of apparently igneous and metamorphic rocks occur abundantly and in these areas opportunities for discovery of pegmatitic, migmatitic and genetically similar types of deposits may exist. 
The Grenville Group paragneiss (identified as bqp on the geologic map of New York) in the Northwest Lowland is a complex of injected, metamorphosed, and replaced rocks, that have been described by Engel and Engel (1953 b). Generally it is a quartz-biotite-feldspar gneiss, but where it is intimately associated with granite-like rock it may include garnet and sillimanite. The structural interrelationships of gneiss and marble are complex, and various interpretations have been offered, but the details are of no particular significance for this report. The one major feature stressed by Engel and Engel $(1953 \mathrm{~b})$ is that the gneiss forms a stratigraphic unit intercalated between the two large and distinct zones of marble in the Grenville Group with no marked unconformity at either contact.

In the area west and north of Balmat and Sylvia Lake, pyritic graphite-bearing schist is found in the limestone adjacent to the paragneiss (Figure 11). The schist is believed to have evolved from an argillaceous calcareous sandstone that may be an integral part of a fairly continuous gneiss and marble sequence. This bed attests to the partially anoxic marine environment in which at least some of the Grenville Group sediments were deposited.

Engel and Engel (1953 b) have described the gneiss within a belt between Balmat and Edwards as consisting of paragneiss, migmatite, and gneissic granite (Figure 12). Reconstitution of the paragneiss within this sector is obviously minimal, occurring only as thin layers and lenses. Reconstitution apparently is a function of distance from the igneous-dominated Central Highland, As the distance away from the igneous massif of the Central Highland increases, the gneissic layers are less apt to be affected by reaction with what they consider to have been granite magma. The reconstituted layers of paragneiss are inter leaved and intertongued with pegmatite and granitic veins and sheets transitional into granitic augen gneiss and gneissic granite. 


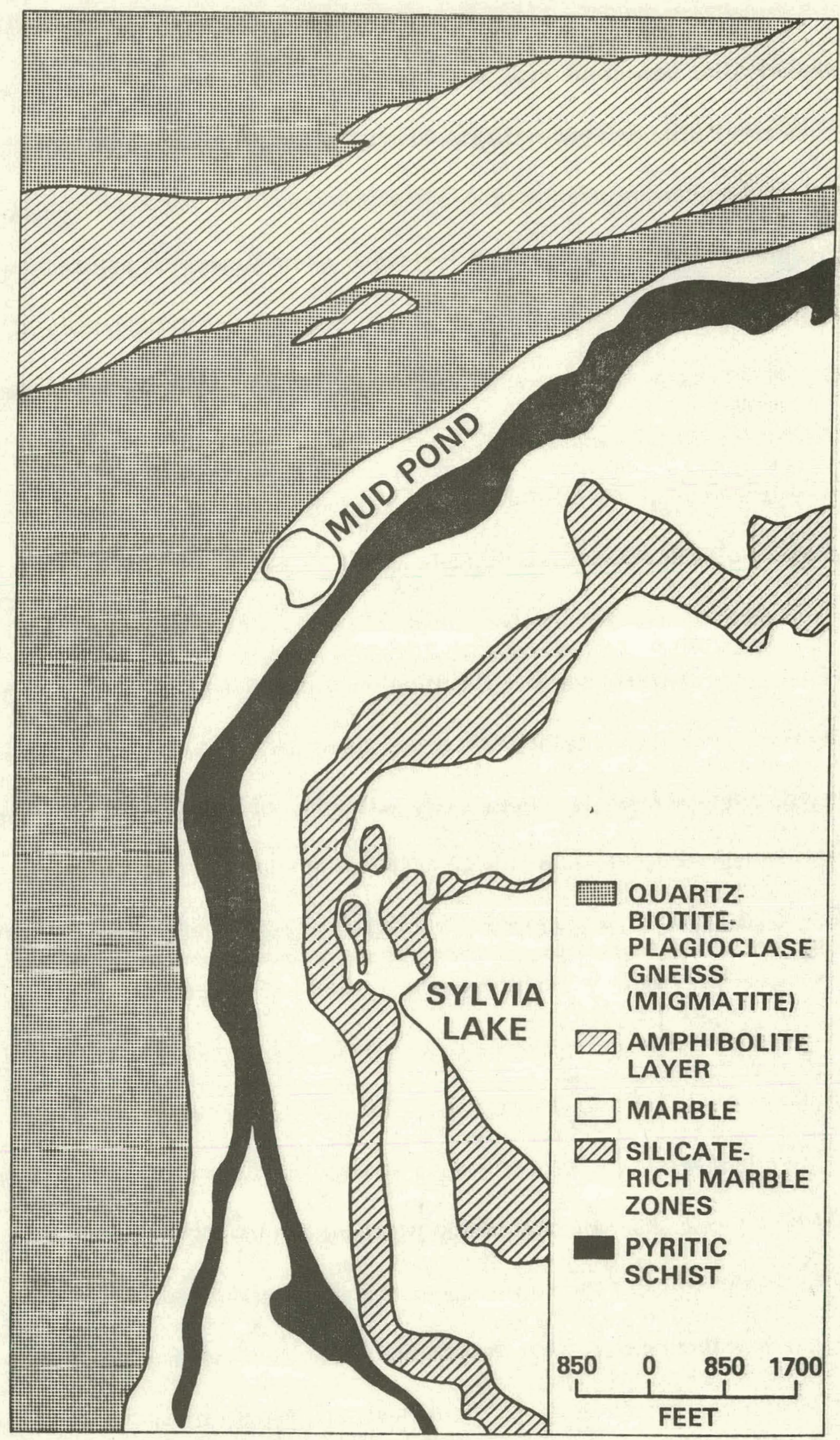

Figure 11. Pyritic schist layer in marble at Sylvia Lake, Adirondack Lowland (after Engel and Engel, 1953 b) 


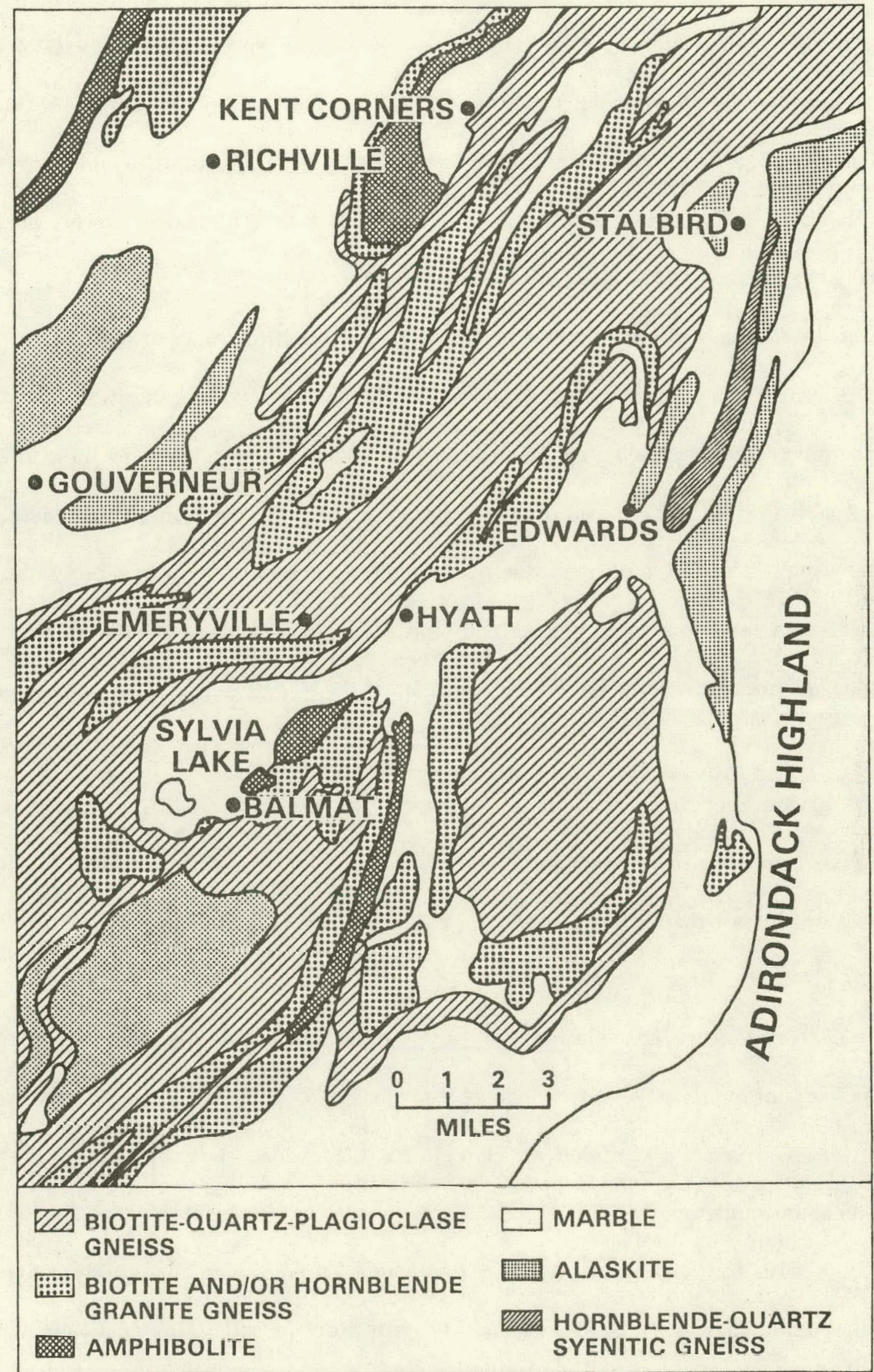

Figure 12. Geology of the Balmat-Edwards-Gouverneur region, Adirondack Lowland (after Engel and Engel, 1953 b, and Geological map of New Y Y 63 k, 1970). 
The components are emplaced along foliation planes in the gneiss and are also commonly transgressive. They range from paper thin sheets to layers or veins tens of feet thick. These reconstituted granite-like rocks are characteristically associated with the paragneiss in the Northwest Lowland and are considered to be largely of replacement origin. They have been interpreted as originating from volatile-rich magma and fluids related to the granites of the Central Highland but emplaced at lower temperatures and pressures.

Prior to metamorphism and reconstitution, or injection, the paragneiss is believed to have been monotonously uniform in composition. Granitization has, however, introduced chemical and mineralogical changes that appear to have involved a marked addition of alkalis, particularly potash, and a diminution in magnesia, iron, and lime. The least altered gneiss includes a greenish-brown variety of biotite, whereas reddish-brown biotite commonly appears in the injected migmatized and granitized gneiss. Garnet also is common in the granitized gneiss and is presumed to have developed from the granitic fluids by reaction with gneiss or, specifically, the biotite therein. The garnet is most often associated with pegmatite veinlets and was probably developed contemporaneously with pegmatite formation. Where it is found in gneiss that is only slightly granitized, it is formed at the expense of biotite.

The conformable relationship of the gneiss to stratigraphically adjacent thick and extensive uniformly-layered carbonate and quartzite suggests strongly that the gneiss is derived from a common and persistently abundant sediment such as shale or argillaceous sandstone. The high $\mathrm{Na}_{2} \mathrm{O} / \mathrm{K}_{2} \mathrm{O}$ ratio in the least altered gneiss is incompatible with this interpretation and is thought to be due to diagenetic-marine or metamorphic process. Graywackes and granodioritic tuffs also approach the 
gneiss in composition and both are possible sedimentary antecedents.

The granitic components of reconstituted paragneiss bear a seemingly consistent paragenetic relationship to the gneiss, and uniform compositional and textural granitic features permeate the entire Grenville Group of the Northwest Lowland. The granitic features are especially manifest in lenses and irregular masses of pegmatite and migmatite along the margins of the gneiss, partly interfingering with it and partly projecting into associated marble, quartzite, and amphibolite. The volume of this material is often considerably greater than that of the gneiss proper, but the anatexis or othor processes of pegmatite, migmatite, and vein evolution have not obliterated the sedimentary relicts.

DEPOSITIONAL ENVIRONMENT OF THE GRENVILLE GROUP, ADIRONDACK LOWLAND

The Grenville Group in the Adirondack Lowland is characterized by a eugeosynclinal type deformation, although lithologically, in the absence of conglomerates, graywackes, pillow lavas, and other geosynclinal types, it appears somewhat atypical of geosynclinal environments. Engel and Engel (1953 b) conclude that the characteristics of this group of rocks fit best the concept that they were deposited either on a part of the earth's crust that was less stable than the usual floors of shelf seas or on the less active and marginal shelf segment of a eugeosyncline, i.e. in an intracratonic basin or miogeosyncline (miogeocline). The anhydrite layers suggest that for a time at least sedimentation seems to have occurred in a restricted highly saline sea. The concept of periodically enclosed seas is consistent with the bitumen (now graphite) content of the marbles, the occasional halite, the silica (probably originally chert) interlayers in the marble, and with the pyrite and graphite in many interlayers in the gneisses. 
Reconstituted Paragneiss as a Possible Uranium Host Rock

Pyrite is present in the Northwest Lowland paragneisses in small amounts in many places. It also occurs in facies of quartz-rich rock, to which it imparts a rusty brown color on weathering, and as disseminated grains in pyroxene gneiss associated with marble. It, and in places pyrrhotite, is locally a common minor accessory in some gneisses and skarns. The migmatite gneisses may locally carry as much as several percent pyrite. These rocks characteristically wealler to a brown rusty crumbly outcrop in zones that have considerable length and thickness. Buddington and Leonard (1962) record pyrite and/or graphite in Northwest Lowland Grenville Group rocks at several localities:

(1) Disseminated sulfide in lenses of pyroxene gneiss in marble in a belt through West Pierrepont and Moores Corner and in a belt through Stalbird and Scotland.

(2) $\mathrm{H}_{2} \mathrm{~S}$ odor in marble from southwest of Snyder Lake.

(3) Disseminated sulfide in pyroxene gneiss in beds in marble nanr Brownoville Bchuol.

(4) Graphite in pyroxene-quartz-feldspar gneiss and interbedded marble in a narrow belt west of Knott School.

(5) Graphlte, disseminated and locally abundant, in marble and diopside granulite, which is also pyritic, in an elliptical belt in the Leon Pond syncline west of Round Lake.

(6) Rusty pyritic gneisses near the eastern boundary of the garnet gneiss area southwest of Browns Bridge; near the western border of the Potsdam quadrangle west of Colton, in the gorge between Colton and Browns Bridge; in the valley of the Raquette 
River a little more than 1 mile below Rainbow Falls; one-half mile north of Browns School; all in the Potsdam quadrangle.

(7) Pyritic gneiss in the garnet gneiss near Van Rensselaer Creek (Canton quadrangle).

(8) Very conspicuous rusty-weathering pyritic gneisses in the hills southwest of the bridge at Hermon (northwest Russell quadrangle), made up partly of garnet-biotite-quartz-feldspar gneisses and partly pyroxene gneiss.

(9) Pyrite-chlorite schist in the bank of Elm Creek 0.4 miles north of the bridge at Hermon.

(10) Pyritic layers in gneisses between Hermon and Stellaville.

(11) Pyritic pyroxene gneiss layers in lenses within marble west of the road 1.2 miles nor theast of Edwards and at numerous places 'within the belt of quartz-feldspar and pyroxene gneisses on the southeast side of the road 0.6 miles southwest of Owens Corners (north Russell quadrangle).

Much of the normal pyritic gneiss is probably metamorphosed sediment containing lenses rich in sedimentary iron sulfide. Local concentrations of pyrite have been interpreted by 'Buddington and Leonard (1962) as hydrothermal replacement veins, but it seems more likely that these are the product of metamorphic reworking of sedimentary pyrite. In the eastern Adirondacks, biotite-quartz-plagioclase gneisses, such af those common to the Northwest Lowland, carry several percent pyrite and graphite locally (Alling, 1918; Kemp, 1904). These rocks, too, are thought to be of sedimentary origin. 
The pyrite and graphite, both in the marble and the gneissic rocks, are evidence of the reducing nature of the original sediments and of the metamorphic rocks formed therefrom. Consequently, where migmatization (or granitization) is most pronounced these rocks could have acted as reduction traps to precipitate any mobilized uranium, as has been suggested for Rossing (Berning, et al, 1976; and Jacob 1974 a). Migmatization, anatexis, or granitization of the Northwest Lowland lithologies, particularly gneiss, appears to be widespread but apparently not on the massive scale evident in the Bancroft region of the Grenville province or in the Rossing arca of Boulh West Africa. Oluvluusly, because of their reduoing nature, where massive reconstitution or granitic injection of the pyritic and/or graphitic paragneisses has occurred, these rocks should be considered favorable for uranium deposits of the Bancroft, Baie : Juhan Beetz, or Rossing type.

The detailed studies by Hauseux (1977) indicate that the granitized Grenville rocks hosting the pegmatitic uranium deposits in the Baie Johan Beetz area were derived by autometasomatism of metasediments (or sediments), and Mackle (1977). has suggested partial melting and anatexis as a contributing factor, buth pronesses having remobilized uranium from the sediments. At Rossing somewhat similar processes, occurring apparently on a larger scale and possibly involving !underlying basement rocks and injection of anatexis-derived fluids, created what on the basis of current commercial developments is a much more favorable uranium environment. By comparison, reconstitution of the gneissic metonndiments in the Northwest Lowland sector of the Adirondacks appears much more restricted in scale thereby possibly limiting their favorability as potential uranium host rocks. It should be emphasized, however, that where field evidence indicates massive high-rank reconstitution of the Grenville Group gneisses, as for instance in proximity to the 
igneous-rich Central Highland, they should be investigated for uranium deposits, particularly in areas where they are known to be graphitic and/or pyritic. Engel and Engel (1953 b) have indicated the more migmatitic, and therefore the more massively reconstituted, gneisses to be compositionally identifiable by reddish biotite or by mixed red and green biotites with the red slightly predominant. Garnet and sillimanite also seem to be more prevalent where pegmatitic material is prominently developed in the gneiss. These compositional components may be useful in providing guidance to the more favorable areas where uranium is likely to occur in the paragneiss as a result of migmatitic, anatectic, metasomatic, or related processes.

\section{Amphibolite and Metagabbro As Possible Uranium Host Rocks}

In the Canadian Grenville province, granitization of the Grenville Group para- . gneisses is commonplace and is apparently a prerequisite for the formation of pegmatite-type uranium deposits. The dominant factors localizing uranium mineralization in these metasediments appear to be the high iron content and the physically confining nature of mafic rocks. such as amphibolite and metagabbro which are interspersed with the Grenville Group metasediments. Where pegmatites inject amphibolite and gabbros, the favorability for uranium appears highest.

Metagabbros and amphibolites form widespread sheets within the granitic gneisses (hbg on the geologic map of New York) of the Adirondack Highland and also are common within the obviously metasedimentary gneisses (bqp on the geologic map of New York) of the Northwest. Lowland. These rocks are described by Buddington and Leonard (1962). The amphibolites constitute metamorphic gneisses in which feldspar and hornblende predominate. They may locally be $r$ ich in pyroxene, 
biotite, or garnet and always contain apatite, magnetite and/or ilmenite as accessory minerals. Some amphibolite grades into metagabbro.

The largest bodies of metagabbro and gabbro-amphibolite within the metasediments are found in the southeast part of the Canton quadrangle and around Stellaville (am on the geological map of New York). Many sheets of these rocks are also interlayered with the biotite-quartz-plagioclase gneiss (bqp on the New York geologic map). At Stellaville on the hill south of the old pyrite mine, the gabbro-amphibolite has partly been altered by granitization and is crossed hy a network of granite pugimatite veins. The intervening rock has been completely reconstituted. The genlngis setting of this area approaches, even if only on a small scale, that which from descriptions of the Canadian pegmatite districts appears to be favorable for uranium, especially where the pegmatites intersect the mafic rocks. Amphibolite is nearly always present in the garnetiferous biotite paragneisses and locally may form as much as 40 percent of their total thickness. Layers up to 10 feet thick arc common and are generally conformable with the metasediments. The amphibolites also appear as thick bodies in marble. They are dominant in rocks separating marble from whacolithic granitelike misses (alaskites), which are abundant in the marble belt, and are also present in layers in the alaskite itself. These amphibolites also commonly grane into metagabbro.

¿uärtz amphibolites are conformably interlayercd with metasedimentary beds in the St. Lawrence County magnetite district (Central Highland) whiru they range in thickness from a few inches to thousands of feet within granitic rocks including granitic gneisses. The layered amphibolite in the granite gneisses that oocur near areas of metasedimentary rocks may be related in origin to the latter rocks. 
A large belt of amphibolite within the Central Highland area extends from the west side of Church Pond (Stark quadrangle) northward and eastward through Catamount Mountain to the west side of Kildare Pond (Childwold quadrangle). This is characterized by a more or less arteritic injection of granitic pegmatite and locally includes sheets of granite. The belt is believed to extend farther south. Because of the extensive inclusion of pegmatitic veins in the amphibolite in this area, it would seem to be a logical target for investigation for uranium favorability.

Granitic materials have been introduced into much of the amphibolite either as arteritic emplacements along foliation planes, thereby producing a migmatite, or as partial replacements of the amphibolite. Apatite in quantities larger than normal appears to be a product of granitization, and both magnetite, which is characteristically a favorable factor in uranium emplacement in the Bancroft pegmatites, and apatite are commonly found enriched in modified gabbro. Where amphibolites have been veined by granitic material and slightly granitized, they commonly carry an abnormally high percentage of magnetite.

Amphibolites occur extensively within the Central Highland as well as the Northwost Lowland. Because of the apparently much more pronounced granitization of rocks in the Ccntral Highland and the higher temperatures and pressures of metamorphism associated with these rocks, the prospects for pegmatite-type, as well as Rossingtype deposits, in amphibolite terrain or other reducing environments would seem to bo grenter there. An extensive study of Central Highland geology and the uranium favorabllity characteriotics associater with that region is, however, a substantial task that could not be undertaken within the time frame of the present study. It would, nevertheless, seem to be a worthwhile project. 
Pegmatite occurrences have been found near DeKalb Junction, Balmat, and Fine, and are also reported to exist at numerous other localities in the nor thwestern Adirondacks (Tan, 1966). Most of the larger pegmatites in the northwest Adirondacks occur in St. Lawrence County. The McLear pegmatite midway between Bigelow and DeKalb Junction in the Gouverneur quadrangle has been mined for feldspar. The deposit contains a variety of minerals including uraninite, molybdenite, allanite, sphene, pyrrhotite, pyrite, and magnetite. The pegmatite at Fine in the Oswegatchie quadrangle contains sphene and pyrite among other minerals, as well as fluorite veinlets.

Tan (1966) lists a number of other pegmatite localities and gives references to literature pertaining to these occurrences. A number of these contain uranium minerals. Unfortunately, information on pegmatite-host rock relationshtps is very sparse. Adams, Arengi, and Parrish (1980) provide additional information on pegmatite localities in the Adirondacks.

\section{Alaskite}

Alaskite and alaskitc gneiss (lg on the geologic map of New York) occur in the Northwest Lowland in homogeneous bodies, or as mineralogically and texturally zoned bodies that suggest relict bedding, in association with amphibolite and metasedimentary rocks. More than a dozen alaskitic bodico of from 2 to more than 15 miles in length are scattered throughout the region in the metasediments (Figure 13). The rocks have been described by Buddington (1929), Buddington and Leonard (1962), , Carl and Van Diver (1975), and Foose and Carl (1977). 


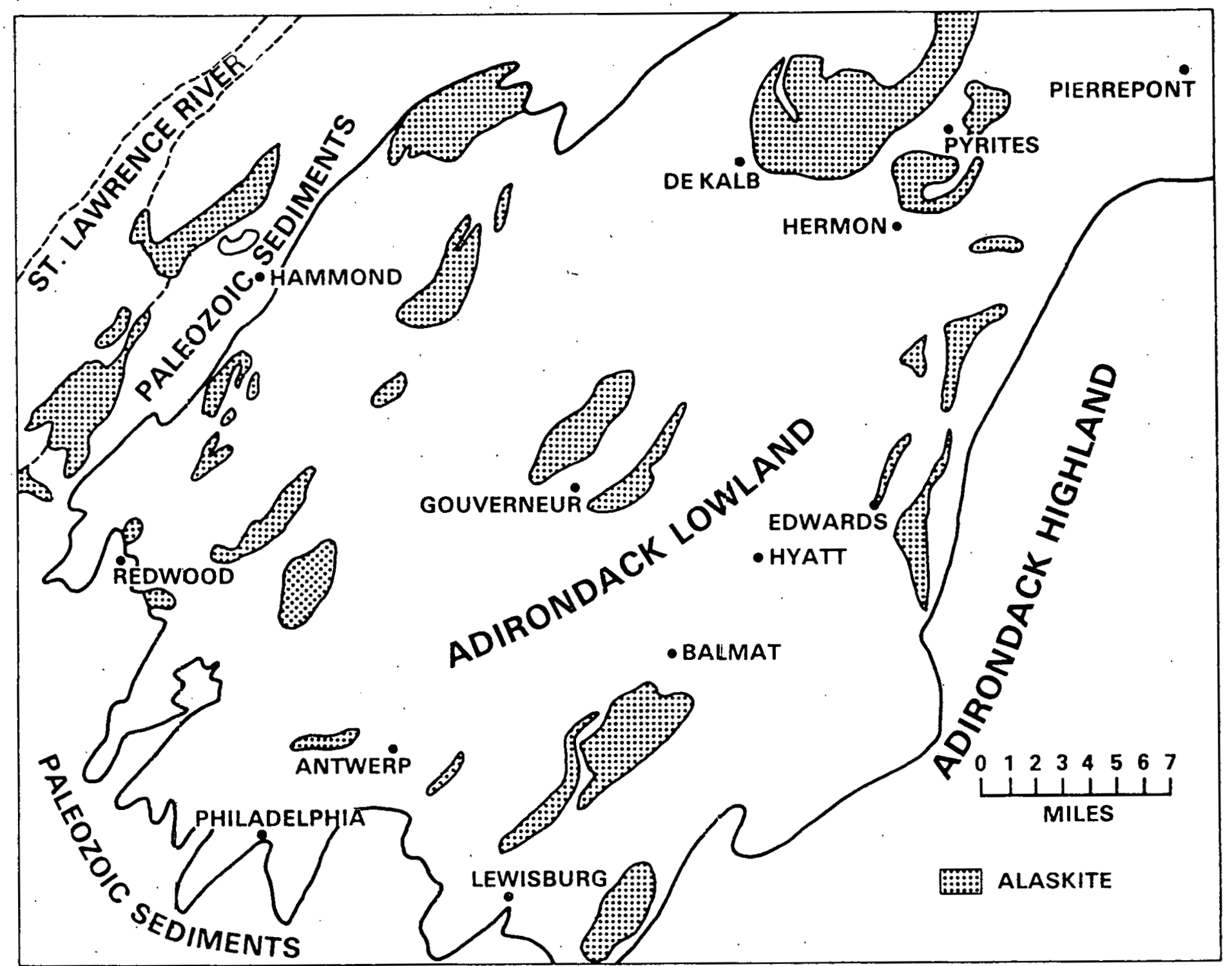

Figure 13. Alaskite bodies of the Adirondack Lowland (after Engel and Engel, $1953 \mathrm{~b}$, and Geological map of New York, 1970). 
Alaskite and alaskite gneiss are also well developed locally as roof facies of hornblende granite and hornblende granite gneiss within the Central Highland, and in all their major belts lie in sheets within the metasedimentary rocks. All are deformed. The alaskite is characteristically high in quartz and low in mafic minerals, which consist chiefly of biotite and magnetite. Fluorite is a noteworthy component in alaskite in the Central Highland and appears to be fairly homogeneously distributed as intergranular material throughout the rock. The alaskite has been interpreted by Buddington and Leonard (1962) as a light highly mobilc magmatic segregation, with a lelatlvely high cononntration of vulatle inaterlal, concentrated initially along the roof of larger granite masses and injected into the metasediments.

All the alaskite bodies have numerous tourmaline pegmatite veins associated wlth them, and all have seemingly metasomatically replaced or otherwise modified in part the adjoining country rock. Where these rocks contain metasedimentary material they are enriched somewhat in apatite, magnetite, and allanite. Most earlicr invesligutors have long regarded these rocks as anticlinal phacoliths emplaced chiefly in carbonate rocks, and Incally in gnoios, duriü metamorphism and folding, but this Interpretation has been challenged by Carl and Van Diver (1975). $\Lambda$ mphibolite layers occur within the alaskite bodies and are regardcd as jart of the general stratigraphic sequence (Carl and Van Diver, 1975). Wherever the aiuplilbullte layers are disrupted, pegmatite occurs in them. The layers are seldom more than 1 meter thick and have been interpretod hy Canl und Van Diver (1975) as sedimentary beds. Upward flowage of alaskite from carbonate interlayers has been cited in earlier accounts for its presence in gneiss, but Carl and Van Diver (1975) consider its association with gneiss to be due to a facies change, folding, or faulting. Thin layers of garnet-sillimanite gneiss, carbonatc, and biotite schist within the 
alaskite (Gouverneur body) are believed to represent sediment deposited during breaks in the emplacement of alaskite parent material. Carl and Van Diver (1975) conclude that the alaskite and associated gneisses, the amphibolites, garnet-sillimanite gneisses, biotite schist, and other associated rocks all constitute a single depositional sequence which shows variations in lithology from one area to another.

The alaskites in the Northwest Lowland are conspicuously associated with a well-sorted fine-grained metasedimentary rock sequence that has in part been mobilized to form migmatite zones in the paragneiss and veins and pegmatite in the alaskites. Carl and Van Diver (1975) consider the alaskites to be a sequence of ash-flow tuffs of rhyolitic composition, possibly water laid, that show some trend toward chemical differentiation. These volcanic materials were recrystalized during folding and metamorphism to form the alaskite. The tuffs were evidently deposited in thicknesses of a thousand or more meters and also finely dispersed over large areas. This interpretation is supported by the chemical composition of the alaskite which is similar to tuff except for some $\mathrm{Na}_{2} \mathrm{O}$ enrichment.

Conceptual Uranium Favorability of Alaskite and Associated Rocks

The consequences of the interpretation of the volcanogenic origin of Northwest Lowland alaskites by Carl and Van Diver (1975) are potentially far reaching insofar as uranium favorability of this region is concerned. One can draw a comparison between the alaskitic Northwest Lowland area and the metavolcanic Kaipokok BayBig River area of Labrador. Both contain metamorphosed volcanics of rhyolitic composition interstratified with metasediments. The metavolcanics of both regions are soda enriched, and, significantly, the uranium mineralization at Michelin occurs within the soda=enriched rocks. Flunrite, which is associated with and widely 
distributed in the uranium host rocks in the Cape Makkovik-Monkey Hill belt is also common in the alaskites of the Central Highland. The Carl and Van Diver (1975) interpretation of alaskites as metamorphosed felsic tuffs, for both Nor thwest Low land and Central Highland alaskites, gives reason therefore to be optimistic about the uranium favorability of this region of the Adirondacks.

The uranium in the metavolcanics at Michelin is in the form of pitchblende inclusions in sphene. Sphene is also a component of alaskite in the Northwest Lowland and Central Highland but is described as rare in the two Northwest Lowland alaskite bodies studied by Carl and Van Diver (1975). The uranium deposits in rhyolitic rocks in the Cape Makkovik-Monkey Hill belt, on the other hand, consist of pitchblende free of sphene. Other uranium occurrences in the general area (White Bear Mountain-Walker Lake belt) of the Michelin deposits are found in rocks other than rhyolite. One deposit occurs in a mafic tuffaceous calc-silicate (skarn-like) rock associated with rhyolite and amphibolite. Both skarns and amphibolites are intimately associated with the presumably volcanogenic alaskites in the Adirondacks. Somc are present in quartz-feldspar porphyry and others in felsic tuffaceous inclusions in granite and granite gneiss.

Of especial interest are several interpretations given for the origin of rhyolites and uraniferous sphene in the Michelin area. One concept of particular relevance regards the rhyolitic rocks as lavas, ash-flow tuffs, and volcanogenic sediments modified by fluids of either hydrothermal or meteoric origin, in which uranium enrichment was brought about by episodes of leaching, mobilization, and depositional processes. This concept brings the rhyolites more in line with the alaskites of the Adirondacks and reinforces the concept of uranium association with tuffaceous rocks. The uranium was precipitated from the mineralizing fluids by reaction with a 
titanium-bearing mineral, in this case sphene, which is a common accessory mineral in rhyolites, as a consequence of the uranium-scavenging propensity of titanium (c.g. its use in extracting uranium from sea water). Subsequent recrystallization of the sphene produced the exsolution texture exhibited in the pitchblende inclusions in sphene. Although sphene is a fairly sparse accessory mineral in the Adirondack alaskites studied to date, iron-bearing minerals, which hypothetically create favorable geochemical loci for uranium emplacement in reconstituted granitic alaskitic, pegmatitic, and migmatitic rocks injected into or passively metasomatically replacing metasediments, are prevalent in Northwest Lowland alaskites or in the interspersed or adjoining metamorphic rocks. Magnetite, pyroxene, and hornblende have already been mentioned as factors in uranium emplacement as constituents of para-amphibolite and metagabbro at Bancroft. There are also strong indications that deposition of primary uranium in. alaskitic occurrences of the Rossing area is influenced by its association with magnetite and with biotite-schist xenoliths. Although low in titanium, the gross mineralogy of the alaskites in the Northwest Lowland includes such principal mafic minerals as biotite, hornblende and diopside-augite, as well as magnetite, all of which could conceivably bring about uranium precipitation by reduction.

Another interesting comparison can be made between the Kaipokok Bay-Big River area and the Northwest Lowland, involving the existence in both areas of carbonaceous argillaceous metasediments and volcanic tuffs. In the Kitts area (Labrador), uranium (pitchblende) deposits occur within graphitic, iron-sulfide (pyrrhotitic) bearing lenses in metamorphosed argillite. The uranium in these deposits is attributed to volcanic source rocks that are abundant and widely distributed in the region. The Northwest Lowland paragneisses, as well as schist within the marble, are pyritic and graphitic. and presumably derived from carbonaceous shale and/or argillaceous sandstone. A 
belt of pyrite deposits about 40 miles long in the Grenville Group paragneiss has been studied isotopically by Buddington, Jensen and Mauger (1969), who concluded that the pyrite was of bacterial origin, i.e. produced from $\mathrm{H}_{2} \mathrm{~S}$ generated by sulfatereducing anaerobes. The interpretation of alaskite as originally felsic tuffaceous sediment completes the analogy between this region and the uranium-favorable setting of the Kitts area. Because the age and paleogeographic relationships between the metamorphosed rocks of the Northwest Lowlands are difficult to decipher, it is not clear whether the spatial and temporal relationships between the tuffs (alaskiles) and the pyritic carbonaceous shales (paragneisses) would have permitted uranium premetamorphically to have been mobilized from the former and emplaced in the latter. Fven in thc absence of this knowledge, however, and in spite of uncertainties in the interpretations of the lithologies, one should consider the graphitic-pyritic metasediments as potentially favorable for uranium of volcanogenic origin from a conceptual standpoint if for no other reason.

The close association of alaskites of tuffaceous origin with carbonaceous and pyritic marbles (formerly limestnnes) in the Adirondack Lowland is also of interest as lils geologic setting is suggestive of, if not fully comparable to, the geologic setting in the Pena Blanca area of Mexico. The favorability of the limestnnes in the Lowland, like those at Santa Eulalia, Mexico, for ore deposits associated with reducing environments is evident in the pyritic sphalerite deposits of the Edwards-Balmat district. Although originally thought. to be hypothermn.l or possibly utusuthurmal replacentent deposits derived from ore solutions from underlying igneous rocks, they have more recently been interpreted by Buddington, Jensen, and Mauger (1969): as the product of precipitation from circulating brines or connate waters by bacteriogenic sulfide. The interpretation given in an earlier section of this report by this writer for the geochemical control of the Pena Blanca uranium deposits by $\mathrm{H}_{2} \mathrm{~S}$ generated by sulfate-reducing bacteria 
from organic matter in the limestone reefs may therefore be applied with some degree of confidence to the alaskite/carbonate environment in the Northwest Lowland, thus calling attention to still another conceptual uranium-favorable setting that possibly merits investigation.

The term "alaskite" has certain connotations of favorability that are immediately associated with the Rossing uranium deposit in South West Africa. Undoubtedly, not all alaskites are generated under circumstances that provide for uranium favorability, nor are all likely to be representative of favorable Rossing lithologies or of modes of formation by migmatitic, metasomatic, anatectic, and other replacement or metamorphic processes which assimilate uranium from uraniferous host rocks. The transposal of uranium favorability criteria of the alaskitic rocks of Rossing to the Adirondack Mountains is highly speculative and tenuous. Nevertheless, in spite of numerous real and conceptual differences, there are also some resemblances that may form a sufficient bridge between the two areas to encourage interest in investigating the alaskite of the Adirondack Mountains for uranium deposits of the Rossing type.

In both areas, alaskite contains magnetite and is associated with biotitic metasediments (as xenoliths or peripheral bodies). These iron-bearing constituents are recognized at Rossing as a factor in uraninite emplacement. In both areas, volcanic rocks are recognized as a possible parent for the alaskite, although other proposed origins are perhaps more acceptable for the Rossing alaskite. Both areas contain metasediments, adjacent to and/or replaced by the alaskite, with graphitic and pyritic reducing environments conducive to uranium precipitation. As already mentioned, Jacob (1974 a) has proposed that the sulfides in the alaskite-replaced metasediments at Rossing were instrumental in uranium preoipitation. Fluorite veins (with quartz) 
that are radioactive are associated at Rossing with certain zoned pegmatites. Thcy are believed to represent a late hydrothermal phase of pegmatitic activity in the area, but whether the fluorine was involved in emplacement of uranium in the major alaskite ore body is problematical. Fluorite is prevalent in alaskite in the western Adirondack Highland region and may warrant study as a pathfinder mineral that could aid in the search for potential sources of uranium there.

\section{URANIUM IN BLACK SHALES OF SWEDEN AND NORWAY}

$\underline{\text { Introduction }}$

Vast resources of uranium are known to occur in black shales in Sweden (OECD/AAEA, 1980; OECD/IAEA, 1977). The Ranstad uranium deposit in Billingen, Vastergotland, is the largest low-grade uranium deposit of its tenor in the world, containing at least 300,000 tons of technically recoverable uranium at a grade of $0.025-0.032$ percent. The occurrence is in Upper Cambrian stratiform black shale that covers an area of about $500 \mathrm{~km}^{2}$. The uranium-bearing layer is 2.5 to 4.0 meters, thick and contains about 22 percent organic matter and 13 percent pyrite. About 90 percent of the uranium is homogeneously distributed in the mineralized seam, and the remainder is concentrated in carbon-rich lenticular nodules, averaging 4 or $5 \mathrm{~cm}$. thick, that occur in bands within the seam.

The alum shales, in which the Ranstad deposit occurs, lie within the provinces of Narke, Ostergotland, Vastergotland, Skane, and on the islannd of Oland (Figure 11). Another large body of alum shale is situated along the border of the Caledonian Scandinavian Mountain range in west central Sweden. The alum shales are for the most part of Cambrian and Lower Ordovician ages and comprise a number of horizons. Descriptions of the general geology and uranium geology of the shales are provided 
PALEOZOIC ALUM SHALES

1. NARKE

2. OSTERGOTLAND

3. VASTERGOTLAND

4. SKANE

5. OLAND

6. BORDER OF SCANDINAVIAN MOUNTAIN RANGE

(TASJO DEPOSIT)

7. OSLO GRABEN

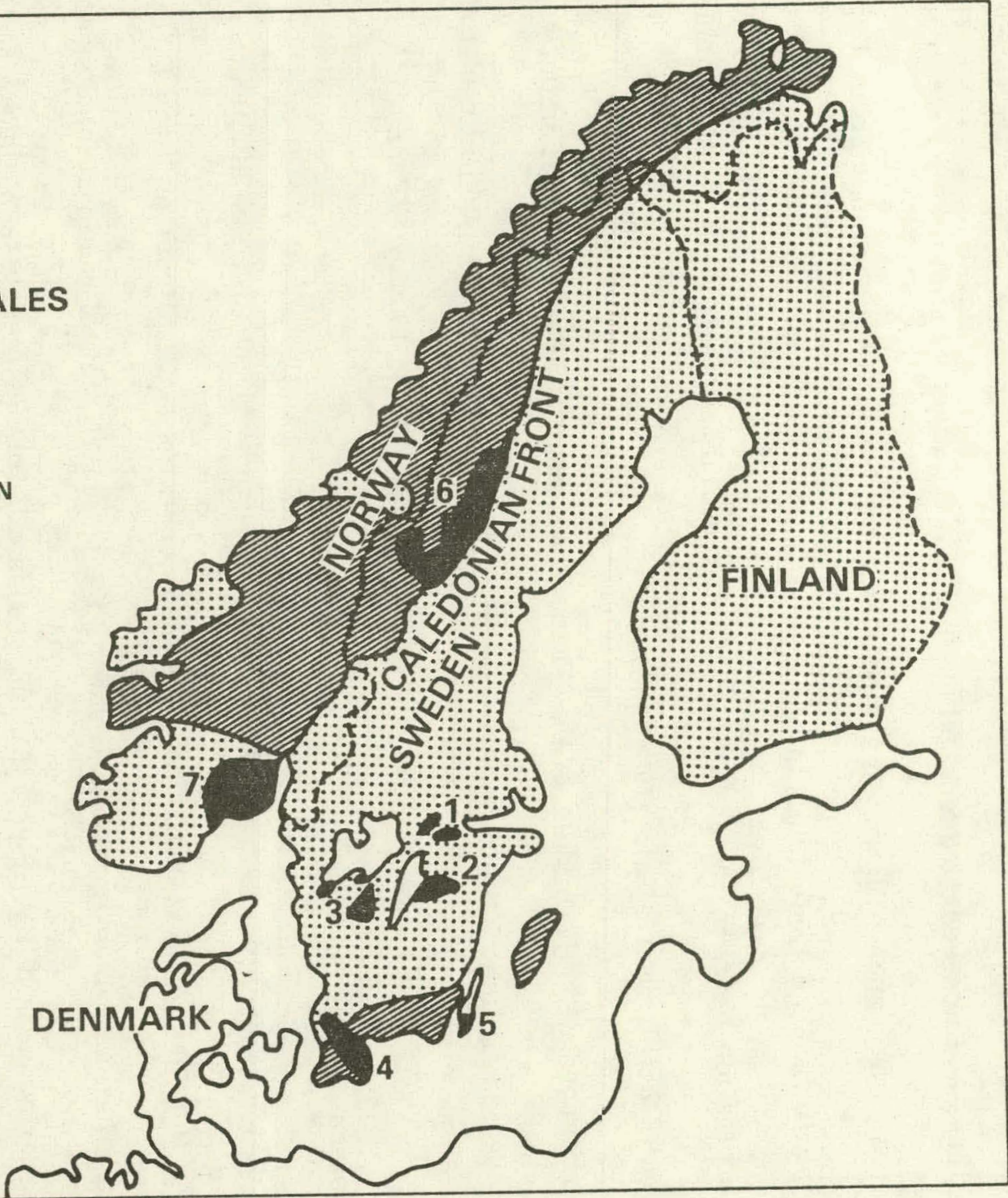

Figure 14. Distribution of alum shales in Sweden and Norway (after Armands, 1972, and OECD/IAEA, 1980). 
in papers by Davidson (1961), Armands (1972), and Cobb and Kulp (1961), which were consulted for purposes of this study.

The shales are underlain by Lower Cambrian sandstones and overlain by Lower Ordovician shales and limestones. The Ranstad deposit is associated primarily with the Peltura (Peltura scarabaeoides) faunal zone, but other uraniferous zones are associated with Olenus, Dictyonema, and Ceratopyge shales which range from Upper Cambrian to Cambro-Ordovician in age.

Correlation hetween the Pcltura zone and faunal assemblages in North America is difficult, but Howell et al. (1944) indicate in their correlation chart that this zone may correspond with the middle of the Franconian stage of the Upper Cambrian which is represented by the Elliott Cove series of southeastern Newfoundland, by unnamed (i.e. in 1944) beds of Cape Breton, Nova Scotia, and by the Narrows Formation of southeastern New Brunswick.

Black-shale uranium deposits of the size and grade of the Swedish alum-shale deposits, if found in the United States, would constitute a significant addition to the U. S. uranium resource base. Recause of the potential size of shale-related uranium resources, the possibility of uraniferous shales existing in the eastern United States seemed to warrant examination in keeping with the goals of this study. The following report therefore attempts to develop some concepts regarding possibilities for uraniferous black shales in the Appalachian region of the New England province, taking into account the major elements of the continental geology and tectonics of western Europe and the eastern United States that may have affected the early Paleozoic development of geochemical and geological cnvironments suitable for uranium deposition in shale. 
Several important facts or considerations seemed germane at the outset. Firstly, no uraniferous black shales of any consequence have, to the writer's knowledge, been reported in the New England province. Secondly, because of the intense folding of geosynclinal strata in the region, uraniferous shale beds a few meters thick could easily have been missed, particularly in a region where rocks are largely buried beneath glacial cover. Thirdly, in the sparse English-language literature on the Swedish shales there is no evidence of a specif ic reason for these shales to have been enriched in uranium except that they were unusually rich in organic and sulfidic constituents characteristic of an anoxic, euxinic environment that is generally favorable for reduction and precipitation of mobile polyvalent elements. Finally, although the principal Cambro-Silurian alum shales of southern Sweden are platform sediments, alternating with neritic limestones indicative of shallow-water deposition, uranium is also associated with similar shales to the west in a region transitional between the stable platform and the geosyncline to the west. Consequently, although platform environments which provide for sedimentation in relatively shallow basins with stagnant anaerobic bottom conditions appear to be highly suitable for formation of uraniferous black shales, the hinge zone and slope between cratonic platforms and miogeosynclines, or eugeosynclines; appear aloo to be conducive to deposition of uraniferous shales. Depositionally and tectonically analogous settings appear to have existed in the Appalachian mobile belt during the Lower Paleozoic, thus giving added justification for this study.

Geologic Setting of Uraniferous Alum Shales in the Platform Environment

Alum shales occur in virtually all the Cambro-Silurian sequences in southern Scandinavia (Rutten, 1969). They constitute a facies containing varying amounts of 
biogenic material. Where this organic matter is sufficiently concentrated, the shales are typically black and commonly oil-bearing. The term alum shale derives from the medieval production of alum $\left(\mathrm{KAl}\left(\mathrm{SO}_{4}\right)_{2} \cdot 12 \mathrm{H}_{2} \mathrm{O}\right)$, from pyrite as a source of bleaching agent for the textile industry, thus calling attention to their high pyrite content. The pyritiferrous alum shales of Sweden locally grade into bituminous shales containing coaly (kolm) lenses. Both the black shale and the kolm have acquired importance for their uranium content. The principal uraniferous alum shale has been dated by Coḅb and Kulp (1961) at a minimum of $500 \mathrm{~m} . \mathrm{y}$. (Middle Upper Cambrian) on the basis of $\mathrm{U}-\mathrm{Pb}$ measurements on the kolm and associated black shale from the Peltura beds.

Regionally, the platform sediments of Cambrian to Silurian age are preserved in Sweden only in small disconnected areas in local grabens and under resistant dolerite cap rock. The sediments are undisturbed except for slight tilting and faulting. They rest on Precambrian rocks of the Fennoscandian Shield and constitute the epicontinental counterpart of the geosynclinal Caledonides (Caledonian orogenic belt) lying to the west. The area in which they are located is relativcly unaffected by the Caledonian orogeny, which ended with the Silurian, and is comparable to the stable interior of North America (e.g. Appálachian Plateau). The sediments are composed mainly of a succession of shales and limestones which show lateral variation typical of epicontinental deposits in shallow seas receiving sediments from local source areas.

Cambrian alum shales comparable to those in Sweden also occur in the Oslo Graben (Figure 14) of Norway where they contain uranium-bearing beds 10 to 15 meters thick with an average uranium content of $100 \mathrm{ppm}$ (OECD/IAEA, 1980). 
The shales extend laterally for hundreds of square kilometers and have a high carbonate (up to 50 percent) content. The graben sediments appear to be transitionall between the epicontinental facies, characteristic of the unfolded Cambro-Silurian Swedish platform, and the geosynclinal facies of the Caledonides where the CambroSilurian is distinctly folded.

The Precambrian core of the Fennoscandian Shield on which these platform sediments rest comprises the basement of much of 'Sweden and part of Nor way. Much of the material making up the Caledonides of Norway is also of Precambrian age, but these rocks attained their present structure during the Caledonian orogeny. which terminated during the Silurian. The Caledonides form a continuous belt extending from southwestern Norway erratically along both sides of the Norwegian-Swedish border (Figure 14). The lowermost part of the sedimentary geosynclinal cycle of the Caledonides is of late Precambrian age (Eocambrian or Riphean). The cycle commenced with Encamhrian sodimentation in varlolis local basins along the strike of the present orogenic belt and continued on a more regional scale into the Silurian. Thrusting is characteristic of the belt and is generally toward the southeast. Extensive nappes now overlie the stable parts of the shield, to the east of the fold belt. The basal Eocambrian beds (Sparagmite Series) of the Calednnide fold bclt are dominantly red and gray arkoses derived from granitic sources and deposited in local basins. The arkoses alternate with shales, limestones, and quartzites which predominate in the more extensive and widely transported upper part of the serieg.

The basal Lower Cambrian was deposited on a peneplaned surface. developed over a long period of time following the close of the Eocambrian orogenic cycle: It is represented by transgressive marine argillaceous and carbonate sediments and some sands and rare conglomerates. The entire Cambro-silurian sequence is marked by 
repeated regressions, transgressions, regional tilting, and faulting.

A marked difference exists between the very thick geosynclinal Caledonide Cambrian-Silurian facies and the relatively thin epicontinental facies outside of the fold belt. The epicontinental beds comprise a predominantly carbonate sequence with interspersed shales. The geosynclinal sequence, which is more obscure, consists of great thicknesses of clastic rocks, often with many volcanics and thin-bedded limestone intercalations, all now metamorphosed. Transitions between the two occur in the autochthonous Cambro-Silurian along the eastern border of the Caledonian mountain chain and in the Oslo area.

Uraniferous Cambro-Ordovician Sediments of the Caledonides--Transitional Geosynclinal Environment

Stratabound uranium has been known since 1957. in autochthonous sediments of the Caledonides at Tasjo Lake in central Sweden. The occurrence has been described by Armands (1970), Andersson (1971), and Gee (1972) upon whose accounts the following is largely based. The deposit is of interest because of its close juxtaposition and genetic relationship to uraniferous Cambrian alum shales (Figure 14), its occurrence in the geosynclinal Caledonides about $100 \mathrm{~km}$ east of a belt of important copper-zinclead deposits, and its spatial relationship to volcanic rocks resulting from extrusive activity that began in Late Cambrian and reached a maximum in Lower Ordovician time. 'The Tasjo doputil, which is in atrnngly folded lower Palenzonin rocks, lies about $200 \mathrm{~km}$ north of the town of Ostermund, in Vasternorrland County. It occurs in a Lowor Ordovician phnsphnritic calcareous sandstone overlain by black shale (Didymograptus shale) low in uranium and underlain by uranium-bearing Cambrian alum shale containing Pelturit launa. The sandstonc matrix is composed of fine gl:ıconite 
grains, which make up about half of the volume of the rock, and small grains of silicate minerals such as quartz, feldspar, and accessory zircon and tourmaline. Up to 5 percent of the rock is composed of phosphorite grains or phosphorized shell fragments. Layers rich in limestone are composed of calcite together with phosphatized shell fragments most of which are from trilobites. The thicker parts of the phosphatic unit, between Garatsrasksjon and Norraker, contain an average of about $250 \mathrm{ppm}$ uranium, whereas thinner parts, farther east in Kvarnan, contain about 500 ppm uranium.

The Peltura alum shale, which underlies the deposit, has a uranium content of up to $200 \mathrm{ppm}$. The shale is sapropelic and evidently strongly reducing. According to Armands (1970), the phosphorite zone, which represents a transgressive marine facies, was developed on an eroding alum shale surface and presumably derived much of its uranium content as a result of weathering of the shale along a shore line. The uranium was incorporated in the apatite structure, probably in substitution for calcium as in conventional uraniferous phosphorite deposits, and therefore is considered to be syngenetic. No relationship is observed between glauconite and uranium, as this silicate mineral does not have the structure or composition suitable for uranium substitution.

The Tasjo deposit occurs along a tectonic hinge line paralleling the raledonide front. The hinge line, which has its roots in the Precambrian basement, was active as a pivotal axis accommodating downwarping of the basement in the west accompanied by rapid sedimentation from the Eocambrian until deposition of the Upper Cambrian alum shales. Across the hinge line, in the late Precambrian, clastic sediments in the east gave way to clastics and finer sediments to the west. By Middle and Upper Cambrian the region had stabilized with black shale deposition. In the Ordovician, limestone facies in the east passer westward into calcareuus sandstones and shales 
over the hinge zone and then into greywackes. Gee (1972) suggested that the hinge line may have extended throughout much of the eastern Caledonide front, influencing sedimentation, mineralization, and subsequent orogenic deformation on a wide scalc. The stratigraphic succession in the hinge zone region is shown in Figure 15 beginning with Eocambrian Sparagmites Series arkosic sediments overlying crystalline Precambrian basement granites, gneisses, and basic igneous rocks. The:sparagmites are succeeded by a quartzite-shale group of Eocambrian and Lower and Middle Cambrian age. Above this lies a greywacke-shale group extending stratigraphically upward from and including the Lower Cambrian.

The Eocambrian arkose group and other more or less contemporaneous sediments accumulated in basins 'marginal to what was to become the main Caledonian trough. The local downwarping in the Tasjo area reflects the earliest Caledonian instability along the western margin of the Fennoscandian Shield. Subsequent downwarping during Eocambrian and Lower Cambrian time followed a typical Caledonide pattern. During the Middle and Upper Cambrian the hinge zone was relatlvely slable, only to be reactivated in the early Ordovician with resulting renewed westerly subsidence and deposition of turbidite facies in cluse proximity to the llmesluine shelf environment:

The base of the Lower Ordovician unit overlying the alum shale contains notable amounts of glauconite and apatite throughout the Swedish Paleozoic sequences from Slrnno to Tasjo. Phosphatic nodules also appear in the uppermost part of the alum shalc, a relationship that extends into England and Wales. The phosphate unit is enriched in uranium at Tasjo, where it is unusually thick. It is also comparably uraniferous at Billingen but evidently substantially lower in uranium elsewhere. The 


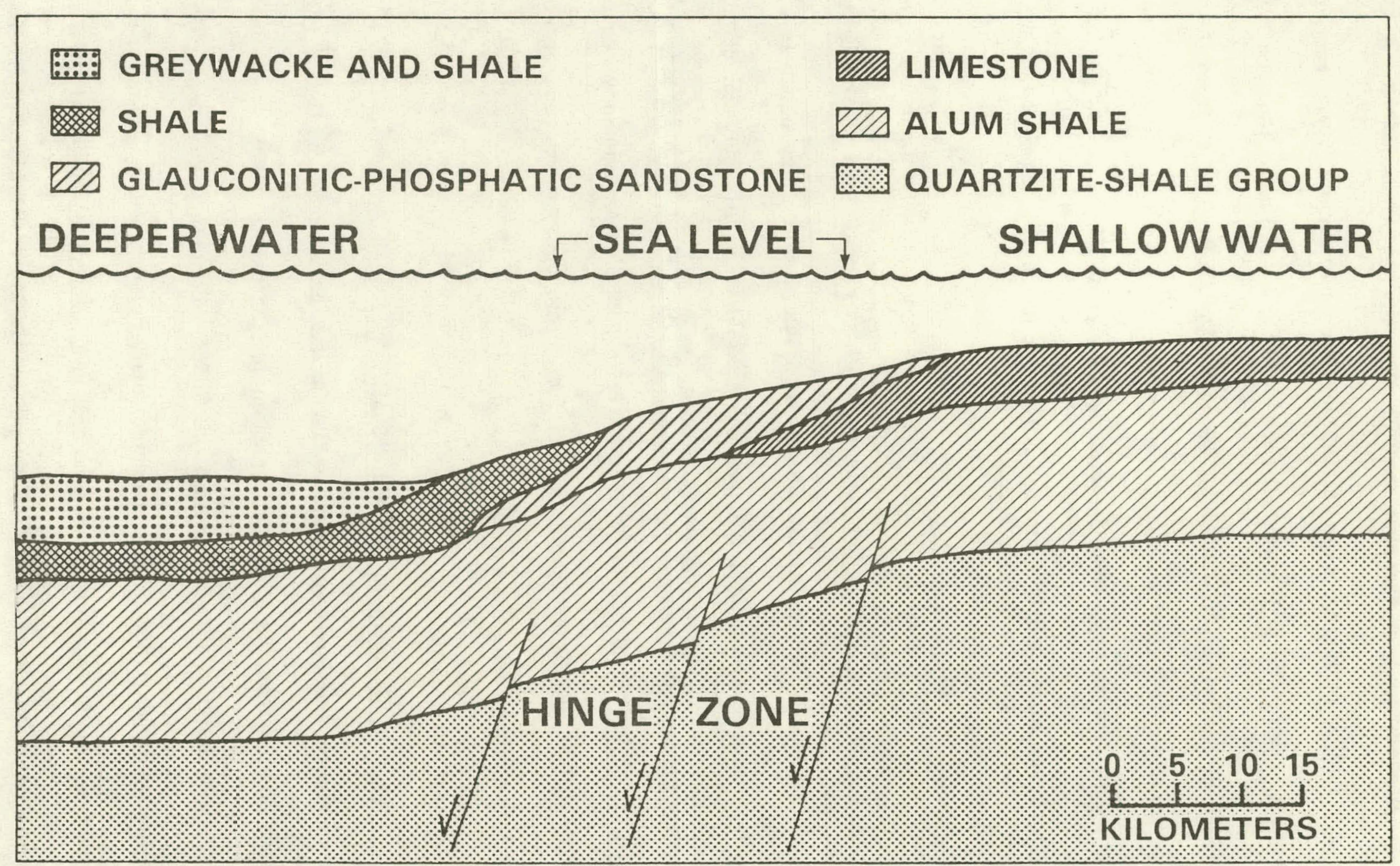

Figure 15. Diagramatic presentation of lithofacies variation from platform to geosyncline at the Tasjo hinge zone, Caledonides (after Gee, 1972). 
Anglo-Welsh nodular phosphate occurrences also contain uranium.

The concentration of phosphate and uranium at Tasjo, where the Lower Ordovician unit is transitional between the stable shelf environment to the east and the deeper water conditions to the west, is explainable, according to Gee (1972), by transportation of phosphate-rich waters by sea currents welling up from the deeper parts of the depositional trough along the edge of the shelf and depositing the phosphate along the shelf edge. The source of the uranium may possibly exist in the alum shales, as suggested by Armands (1970), or it may be the same as that for the alum shales, which is unknown.

The Tasjo Lake deposit, although in itself not particularly important either as an economic source of uranium or as a world-class deposit type to be sought in the eastern United States, brings attention to the fact that uranium may occur in black shale and associated sediments, not only in the epicontinental environment but also in the peripheral geosynclinal belt. What is most important in this respect is that in the latter region the uranium-bearing shale is part of a sedimentary sequence that is transitional westward from platform facies into contemporaneous eugeosynclinal sediments containing acid and mixed volcanics.

Proposed Origin of Uranium in the Alum Shale

Alum shales are found in Europe extending as far west as the United Kingdom where they contain from $50-60 \mathrm{ppm}$ uranium (OECD/IAEA, 1980). The shales may also have been distributed widely within the folded sedimentary sequence of Sweden and Norway where they now occur as schists and gneisses. For example, graphitic mica schists near Ilolandsfjord in northern Norway containing up to $140 \mathrm{ppm}$ uranium are considered to be alum shales metamorphosed during the Caledonian orogeny (OECD/IAEA, 1980). 
The Caledonides of Norway contain rocks deposited in both miogeosynelinil and eugeosynclinal environments (Frietsch, Papunen, and Vokes, 1979). The clastic sparagmites constitute the earliest sediments (Eocambrian to Cambrian) deposited on the Precambrian shield, and initiate fold-belt sedimentation. These are overlain by eugeosynclinal sediments consisting of flysch facies, submarine volcanics, and shoreline conglomerates. The volcanics persist from Cambrian to Silurian time. The eugeosynclinal sequence was metamorphosed and tectonized during the Caledonian orogeny. with intrusion of syntectonic and later orogenic granites and gabbro. Along the Caledonian front the greywacke and shale flysch facies are replaced by limestones and shales which extend eastward. The rocks along the front lack volcanics except for some bentonite horizons and are considered as miogeosynclinal even though the facies and rate of sedimentation are not characteristically geosynclinal. Extensive nappe complexes thrust from west to east are characteristic of much of the Swedish Caledonides. These contain eugeosynclinal sequences metamorphosed to greenschist and amphibolite facies.

The Scandinavian Caledonides contain important stratabound massive sulfide deposits of zinc; copper, iron and lead (sphalerite, chalcopyrite, pyrite, galena) associated with Eocambrian to Ordovician volcanics and sediments. These ore deposits have been affected by the Caledonian or ogeny and are therefore considered older. Although their true nature is difficult to discern because of metamorphism, they are thought to be syngenetic volcanic exhalative deposits (Frietsch, Papunen, and Vokes, 1979). Many of the deposits are related to geosynclinal volcanism that began in the Late Cambrian and reached a maximum activity in Lower Ordovician time. This volcanism was essentially contemporaneous with sedimentation to the east, that produced the uraniferous Late Cambrian alum shales and the overlying Lower Ordovician 
uraniferous phosphatic sands. The volcanic-sedimentary succcssion is now represented by amphibolites and schists of various types. The pyritic sulfide deposits are distributed (Figure 16) along the length of the Caledonides, hence the source solutions must have originated and/or migrated over an extensive area.

Generally speaking, massive pyritic copper-zinc deposits in metavolcanic and metasedimentary rocks originate largely in submarine volcanic environments near the edges of tectonically active troughs sinking and receiving clastic sediments from the continent (Jenks, 1971). These deposits are often displaced by slides and nappes which separate the host rocks from their root zones. The stratabound Scandinavian Caledonide sulfide deposits appear to fit this model. The Archean to Tertiary massive sulfide ores characteristic of geosynnlinal helts throughout the world are lelaled spatially and genetically to effusive and pyroclastic rocks representative of the initial volcanism of mobile-belt development (Vokes, 1976). The ore-forming fluids presumably originated within the magma that gave $r$ ise to the volcanic ronks or were formed from connate waters activated by volcanism. They are, thcrefore, considered to be synvolcanic or volcanogene. The sulfide ore bodies are associated with mafic and/or felsic volcanics, e.g. with basaltic lavas (Norway), dacites (Kuroko deposits ot Japan) or andesites and rhyolites (Noranda, Quebec, and Kuroko, Japan).

A few of the Norwegian massive sulfide nres rontain signifioant amuunts of magnetite, although in most deposits this mineral is present only in minor amounts or altogether absent (Vokes, 1976). Important magnetite ores with up to $3-4$ percent pyrite and minor quantitites of chalcopyrite are also present in the region. These appear to represent a transition between dominantly oxide-phase and dominantly sulfide-phase mincralization. Their existence may be an indication of both sulfophile and oxyphile 


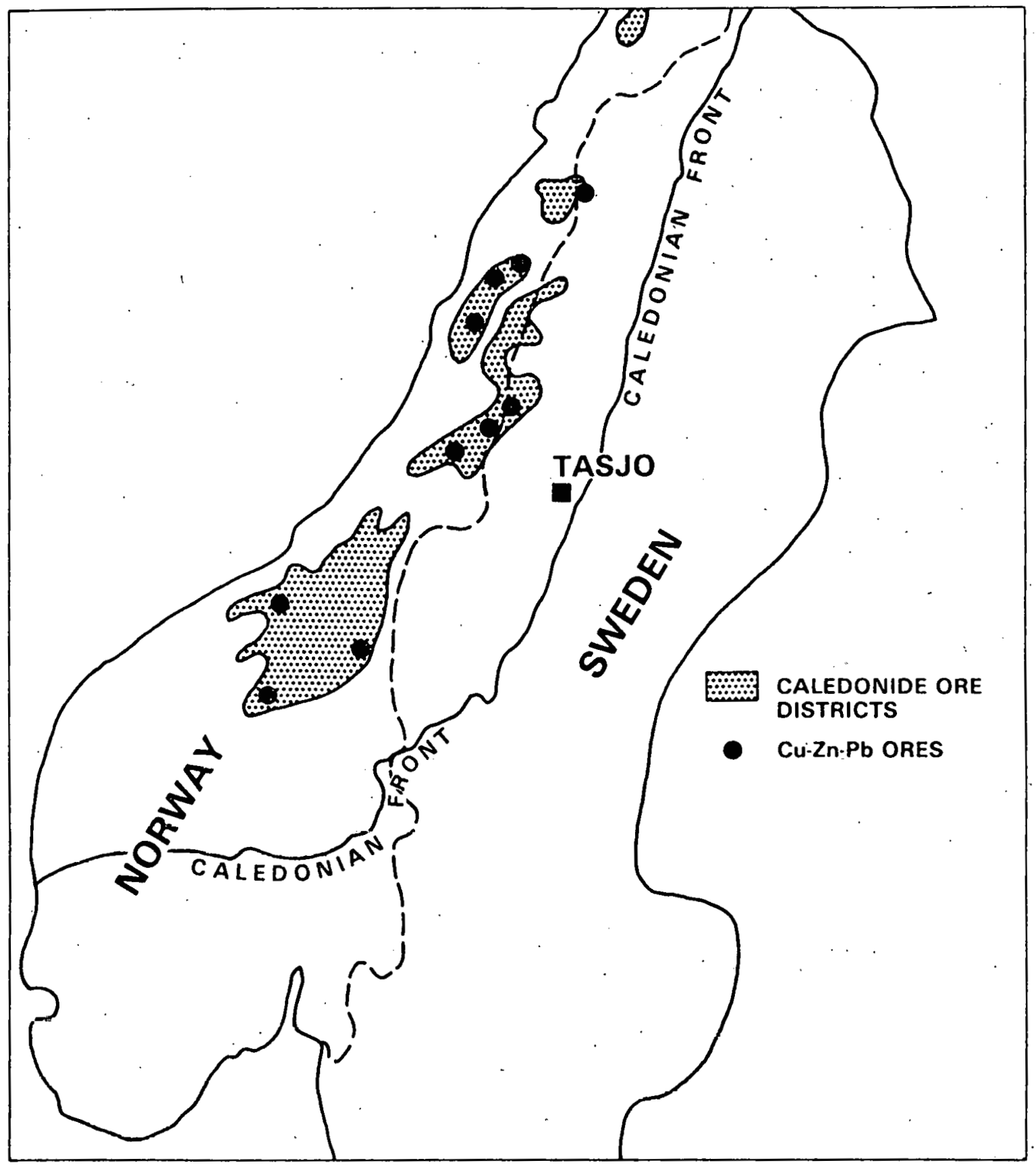

Figure 16. Distribution of Lower Paleozoic $\mathrm{Cu}-\mathrm{Zn}-\mathrm{Pb}$ Ores of the Caledonides (after Frietsch, Papunen, and Vokes, 1979). 
phases within the volcanic source, with iron commonly a constituent of both. The geochemical affinity of various elements for either the sulfide or oxide phase may have an influence on their partitioning and consequent enrichment in certain volcanic cxhalative or hydrothermal solutions and not in others. This may affect their ultimate distribution in the sedimentary environment, i.e., whether they deposit near or far from volcanic source rocks. It is quite probable that this is also a factor in the separation of uranium from sulfide-forming elements in the volcanic chamber and its appearance subsequently either with magnetite in proximal volcanogene deposits in the eugeosyncline or with more distal reducing facies of eugeosynclinal, miogeosynclinal or platform sediments.

Grauch (1978), for example, in interpreting the origin of the Precambrian Camp Smith, New York, uranium prospect, suggested that submarine volcanism supplied an abnormal amount of uranium to a hot water system that circulated through volcanic rocks and sediments beneath thc ocean floor. The chemical elements in the system were deposited near the interface between seawater and sediments where the hot water mixed with cold seawater, with uranium probably depositing in disseminated form in the sediments rather than in economic concentrations. Later metamorphism concentrated the uranium into economic deposits. Grauch's concept derives from the association of ore-grade concentrations of uraninite with host-rock leucogneisses, amphibolites, and amphibolite gneisses (granulite facies). The uraninite occurs in thr outer copper-nlclscl zone of a sulflde ore body, in magnetite-rich and scapoliterich layers within amphibolite gneiss, and in amphibole-quarlz-feldspar (with and without pyroxene) pegmatites. The general setting is one of a thick sequence of graywacke and related sediments and volcanics deposited on an older granitic 
terrain. Both proximal and smaller distal volcanogene massive sulfide bodies were formed in the sediments and volcanics, with uranium generally associated with the latter bodies.

Migration of volcanogenic uranium in sea water and subsequent deposition in ore or protore concentrations has been implied by Grauch, as described above, and by Gandhi (1978), ; as indicated in a foregoing section of this paper. At Camp Smith, migration took place in a eugeosynclinal terrain; in Labrador (Kitts,' Michelin, etc.) it occurred seemingly in an intracratonic environment.

Fisher and : Bostrom (1969) have observed that sediments on mid-ocean $r$ idges associated with sea-floor spreading and high heat flow are enriched in uranium (up to $10 \mathrm{ppm})$, iron, phosphorus, vanadium and certain other elements, presumably as the result of volcanic processes. Calvert and Price (1970) have described a modern marine environment of organic-rich sedimentation with metal enrichment on the continental shelf of South West Africa. The area is the site of intensive upwelling and very high primary organic production in a region where the accumulating bottom sediments are organic- and sulfide-rich. High concentrations of copper, zinc, lead, and nickel occur where the muds are richest in organic matter.

Brongersma-Sanders (1969) has attributed enrichment of metals in black shales to initial concentration in plankton in areas of oceanic upwelling followed by release from the decomposing plankton on the sea bottom. The metals are precipitated at the sea-sediment interface by $\mathrm{H}_{2} \mathrm{~S}$ produced bacteriogenically from the oxygen-deficient decaying organic ooze. Except for locally abundant terrigenous or marine plant matter, plankton, particularly phytoplankton, are the main source of organic matter in the sea. These depend upon mineral salts in the sea as their food and upon sunlight for photosynthesis. Their abundance in sea water is to a large extent dependent 
upon the supply of phosphate. Where phosphate is depleted, the plants do not flourish; where it is abundant, they develop with great rapidity. Hence they thrive best in areas where the surface waters are continually replenished with nutrients. Since deep waters do not mix much with surface waters in the open ocean, the quantity of plankton in the open ocean is relatively small. Nearer land, however; deep waters rich in nutrients derived from submarine sources, e.g. volcanic emanations or geochemical sinks, well up to mingle with surface waters. These nearshore marine areas provide an environment highly conducive to plankton growth. Since phytoplankton are the source of food for zooplankton, both plant and animal life contribute to the organic matter deposited in such nutrient-rich areas. The extent and thickness of existing euxinic facies and their organic and sulfide content is probably the bett measure of the degree to which plankton flourished in paleo-marine waters.

The hinge line area of the Caledonides, which approximates the zone of transition between deeper sea and shallow platform environments, is, according to Gee (1972), a region of upwelling of deep waters. It is also an area of concentration of phosphate in Lower Urdovician sediments. The persistence of these phosphatic. sediments throughout the Swedish platform sequence overlying the alum shales indicates that the platform may have been rich in nutrients moved shoreward possibly by winddriven or tidal currents. This region would alsn, therefore, he characterized by luxuriant planktonic growth and consequently by sediments containing considerable organic matter. With settling and partial decomposition of the plankton, much of their metal content would have been released and deposited along with iron sulfide by anaerobically produced $\mathrm{H}_{2} \mathrm{~S}$. The resulting fetid black shale deposits may become sufficiently uraniferous to constitute economic sources of uranium. 
In summary, then, phosphate, organic matter, and metal content in black shales is related (l) to an abundant initial source, possibly volcanic, of metals from the open sea bottom, (2) to the upwelling of these metals along continental shelf edges and their migration onto the platform, (3) to utilization of the metals as a supply of food by plankton, and (4) to their ultimate deposition as a consequence of anaerobic stagnation of the geosyncline and platform sea bottom.

Analyses of black Upper Cambrian alum shales by Armands (1972) revealed considerable concentration of phosphate along with uranium in these rocks. Phospate content of the shale ranges from 0.2 to 0.3 percent. The Middle Cambrian shales contain only about half as much, suggesting that sea water was possibly being enriched in $\mathrm{P}_{2} \mathrm{O}_{5}$ during the Cambrian to a maximum in Lower Ordovician time when phosphoritic material was deposited in greatest quantity, i.e. in distinct phosphorite beds. The shales are also, interestingly, exceptionally high in molybdenum and vanadium, two elements that are commonly associated with uranium of probable volcanogenic origin (e.g. in sandstone-type deposits).

The proposal of a volcanogenic-planktonic origin for the uranium, if not the phosphorous, and other metals in the highly uraniferous Scandinavian black shale is, of course, speculative, but it does contribute a concept that is useful in (l) removing the implication that discovery of similarly rich éarly Paleozoic uraniferous shale deposits in the United States is dependent on the existence of a specific shale facies correlative with the Peltura-rich Upper Cambrian of Sweden, and (2) placing appropriate emphasis on the geosynclinal and platform biotic and geochemical environments as factors in uraniferous black shale formation.

Vine, Swanson, and Bell (1958) have suggested that uranium in black shales is more effectively incorporated by humic acids derived from land plants than by other 
organic components such as the sapropelic matter from hydrogen-rich marine plant and animal remains from which petroleum is formed. Breger and Brown (1963), on the other hand, conclude from extensive analytical studies of the Chattanooga Shale that both aquatically and terrestrially derived organic constituents are equally effective in retention of uranium. The argument as to whether humic (terrigenous) or sapropelic (planktonic) matter is most important in concentrating uranium is irrelevant insofar as any application to pre-Devonian or pre-Silurian black shales is concerned, since land plants are not recorded to any appreciable extent until Devonian times. Organic matter in black shales of Lower Paleozoic age must have been derived from planktonic sources or from other marine flora of local distribution. Consequently, conceptualization of the processes contributing to enrichment of uranium, and other metals, in planktonic organisms in both epicontinental and open ocean environments is highly germane to the problem of exploring for uranium in Lower Paleozoic black shales.

Organic matter making up the black shales is subject to diagenetic alteration within a reactive system including processes that occurred (l) within the ocean waters and on the depositional surface involving both aerobic and anacrobic bacterial activity, (2) beneath and across the sediment/water interface, (3) abiotically in both immobile and mobile connate water, (4) over distinctive depth/temperature intervals, and (5) after uplift on re-exposure to oxidizing conditions with effertive changes in $\mathrm{pH}$ and $\mathrm{E} h$. The diagenetic processes can alter the balance between the amount of living organic matter produced and the amount of sapropelic matter that remains in the shale luday. They may diminish the ultimate liquid hydro-carbon yield of the shale and result in unwarranted conclusions regarding the original organic composition of the shale. The amount of pyrite in the shale is perhaps a 
rough indicator of the quantity of original organic matter that has been destroyed, at least anaerobically, but it cannot give a measure of the material degraded aerobically before deposition on the sea bottom. Since the ratio of organic carbon to sulfur in average Upper Cambrian alum shale of Sweden is about $2: 1$ by weight, a significant quantity of organic matter must have been destroyed by sulfate-reducing bacteria alone:

Assuming sufficiency of the reservoir, the ultimate quantity of uranium combined with organic matter in the open ocean is a function of the quantity of plankton available and their capacity for uranium up-take. Assuming that none of the planktonic matter is destroyed either aerobically in the oxidizing zone, anaerobically in the anoxic zone, or by any other process, the concentration of uranium in the residual. organic matter in shale is in direct proportion to the original quantity absorbed by the plankton. With complete aerobic destruction of planktonic organic matter, the uranium should be released probably in entirety to the sea water because of its solubility in the oxidized state. Partial aerobic destruction may cause partial release in proportion to the quantity of organic matter destroyed, or there may be some enrichment due to metal-organic complex formation at active bonding sites created by loss of hydrogen or other components. Anaerobic degradational processes on the sea bottom, on the other hand, could result in substantial loss of organic matter and not result in uranium loss to sea water because of the insolubility of uranium in reducing environments. Hence, with continuing anaerobic degradation of organic matter, there would be an increase in uranium concentration (enrichment) in the remaining (residual) organic matter. Uranium released from organic matter undergoing anaerobic decay would tend to become associated with pyrite and perhaps other inorganic components, such as clay, peripheral to the decayed organic matter. The 
greater the quantity of organic matter decayed anaerobically, the higher the concentration of uranium in the deposit.

Apropos to the task of developing concepts of uranium favorability in black shales is the discovery of euxinic black shale facies in existent open oceans and their. documentation on a wide scale in the Lower Paleozoic. Lower Paleozoic oceans are believed to have been more prone to anoxia than younger oceans, thus accounting for the widespread appearance of marine black shale facies in Lower Paleozoic sedimentary sequences (Leggett, 1980). The most spectacular development of such facies was during the Lower Ordovician, Middle Silurian, and Upper Devonian. Because of its importance in Scandinavia, the Upper Cambrian must also be included. The causes of anoxia in the oceans may be multiple, including flooding of formerly dry land and transportation of large amounts of land plant debris out to sea (Jcnkyns, 1980). The latter would apply only to post-Silurian seas. Another causc has already been expounded, i.e. enrichment of volcanic effusive constituents along or near the ocean maryins, producing eutrophic waters containing a luxuriant planktonic milieu which l'dululy created anoxic anaerobic conditions on marginal- and shelf-sea bott.nms, Where development or influx of planktonic matter is high, oxygen consumption by sinking and decaying carbonaceous matter causes expanding oxygen deficiency in sea water. The consumption of dissolved oxygen by decay processes and necompanying inorganic reactions, i.e. oxidation of bacteriogenic. $\mathrm{H}_{2} \mathrm{~S}$ diffusing from the sea bottom, increases as the quantity of plankton increases, thus establishing conditions favorable for the preservation of organic carbon in sea water and its ultimate accumulation on the sea bottom.

The association of uranium with phosphate in seas contributing to sedimentary sequences containing uraniferous black shales warrants further comment. The 
increased phosphate content of upwelling sea areas provides much of the nutritional stimulus for rapid and luxuriant plankton development, with consequent quantitatively greater enrichment of uranium in plankton and the resulting degraded organic matter. The higher the ratio of decomposed organic matter to remnant organic matter, the higher the concentration of uranium in the carbonaceous residuum. High concentrations of phosphate in pelagic and epeiric seas are reflected by phosphoritic deposits on the sea floor.

The association of uranium with phosphatic material is also reflected by bituminous shale horizons in late Albian and early Turonian (Cretaceous) sedimentary sequences in the Venetian (Southern). Alps. In this region pelagic limestones are intercalated with black shales (Jenkyns, 1980). The shales contain on the average $110 \mathrm{ppm} \mathrm{U}_{3} \mathrm{O}_{8}$, up to a maximum of $725 \mathrm{ppm}$, and are phosphatic as well as glauconitic and dolomitic. The shale horizons were formed on a large submarine plateau surrounded by deeper basins which could have given rise to upwelling currents.

Present-day phosphorites have a limited occurrence, being confined to zones of upwelling along west-facing continental margins (e.g. off Peru and South Africa) (Leggett, 1980). In the British Isles, phosphate occurs in Late Ordovician black shales, evidently having been deposited along a broad west-facing continental margin, and in Sweden it is similarly found in Lower Ordovician sediments along the eastern margin (west-facing continental margin) of the proto-Atlantic (Iapetus) Ocean as alrcady dcacribcd. Lcggctt (1080) attributeg phosphate deposition to the establishment of a nutrient trap in deeper shelf and slope environments, below the reach of wind- and wave-driven surface-water overturning, to development of a horizontal layer (thermocline) which is characterized by a rapid decrease of water temperature 
and increase in density with depth. This same stratifying effect and phosphate trapping may occur over a shelf area.

The geochemical cycle of phosphate and various hypotheses on the origin of marine phosphorite have been reviewed by Sheldon (1980). Phosphorous as phosphate is weathered from rocks and enters into the oceans where it is taken into the biological cycle and carried into and enriched in deep water by sinking organisms. The ocean depths constitute a large phosphate sink or reservoir. The phosphate composition of the oceans probably varied episodically during geologic time, high concentrations often leading to primary sea-floor phosphate sedimentation. Cook and McElhinny (1979) observed no dirëct genetic link between periods of volcanism or orogenesis and phosphogenesis. Sheldon (in preparation) concluded that the volcanic contribution to the phosphate content of the oceans has not bèen satisfactorily resolved, but proposed a possible indirect role through alteration of ocean basingeometry and concomitant sea-level changes, the latter causing phosphorous withdrawal from the deep-ocean sink by upwelling.

It is proposed here that volcanism in the Caledonian eugeosynclinal trough produced sufficient warming of the normally cold deep-ocean waters during late Cambrian and early Ordovician time to produce upwelling of phosphate from the deep ocean phosphorous reservoir. The increase in phosphate in surficial ocean waters stimulated rapid and abundant plankton growth and consequent enrichment of volcanogenic uranium, vanadium, and other elements in the marine biota. Enrichment of these metals in marine sediments comprised in part of planktonic organic matter was further enhanced by aerobic and anaerobic degradation of the organic material, the concentration of metals in the organic residue of black shale being roughly proportional to the ratio of anaerobically destroyed to residual organic 
matter. This ratio may to some degree be measureable by the amount of pyrite present in the carbonaceous shale, or more exactingly by the pyrite (or pyritic sulfur) to carbon ratio.

Lower Paleozoic shales manifesting euxinic facies have accumulated in a range of paleobathymetric settings. Shale deposition may or may not coincide with largescale (eustatic) elevations of sea level. Leggett (1980) suggests that sea-level rise was responsible for increased organic carbon productivity in surface waters causing a marked drain on the oxygen capacity of the water mass. The oxygen deficiency created conditions favorable for the preservation of organic matter in bottom sediments. The sea-level rise concept is consistent with transgression and the occasional development of euxinic facies on the continental platform, as for example in Sweden.

The Lower Paleozoic paleogeographic configuration of interest for uranium based on the Swedish shales is one of platform carbonates intercalated with sparse bituminous black shales, and perhaps phosphatic horizons, intertonguing towards the open ocean with thicker marginal shales and clastic geosynclinal facies interbedded with volcanics of island arc origin (Figure 17). Such an environment contains layers of anoxic bituminous sea-floor sediments that spread from the ocean basins across the continental margins onto shelf areas.

Prevailing west to east winds along the eastern (European) proto-Atlantic slope would have driven plankton onto the shelf to settle and accumulate in the epicontinental sediments. Along the western (North American) proto-Atlantic slope, the prevailing winds would Instead have driven plankton eastward away from the shelf thus causing organic matter to accumulate along the continental slope and in miogeosynclinal and eugeosynclinal sediments. Exploration for uranium in ancient black shale facies of the eastern North American continent could therefore justifiably be directed toward 


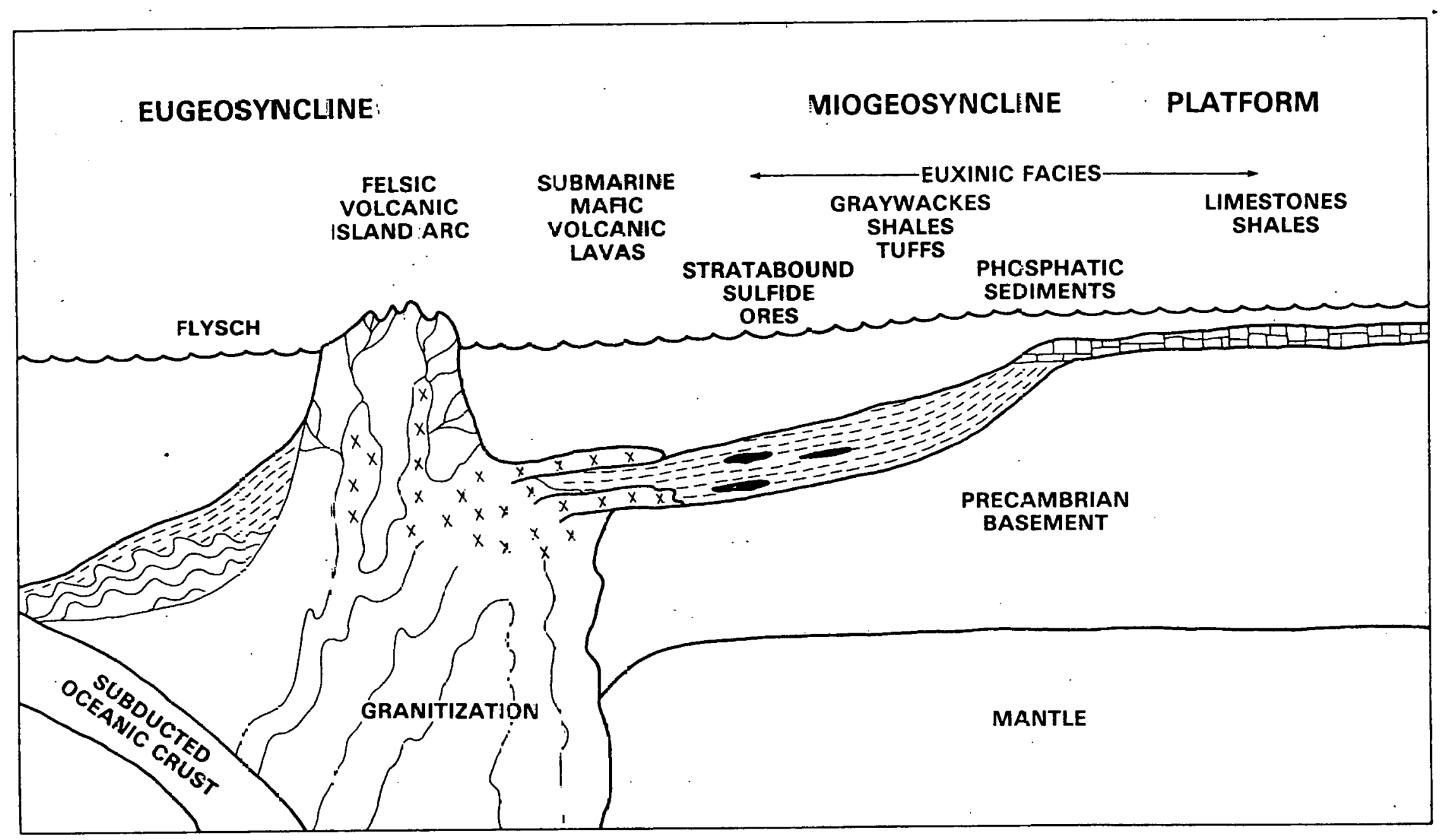

Figure 17. Grogenic and depositional model--platform to eugeosyncline. 
miogeosynclinal and eugeosynclinal sequences.

\section{EFFECTS OF METAMORPHISM ON BLACK SHALE}

Although the foregoing concepts relating to the volcanogenic origin of uranium in black shales are tenuous, a number of other investigators have pointed to volcanism as a source of metals in black shales. Mehnert (1969) considered pelitic sediments containing sapropelic bituminous facies to be often enriched in metals introduced into the sediment by volcanic exhalations, and suggested that these metalbearing shales may be parent rocks for metamorphic or even anatectic rock series. It was suggested that their metal content could readily be mobilized and re-concentrated as pseudo-hydrothermal ore deposits or as infiltrations of the country rock.

Regional metamorphism of metal deposits in sedimentary-volcanic terranes may or may not alter the temporal relationship of the deposits to the surrounding rocks, some deposits being coeval with their hosts and others postdating them (Mookherjee, 1976). Reworking of stratabound deposits can occur through orogenic deformation which simply increases metamorphic grade of the host rocks or with more intensity may result in migmatization or magmatic injection. These effects may be a function of the depths to which geosynclinal zones are subducted or otherwise downwarped. Metamorphism therefore may have incidental or incipient effects on the metal deposit or it may recreate it chemically as well as physically and quantitatively as well as qualitatively. Black shale with some degree of preconcentration of metals may or may nut exhibit metamorphic reconstitution.

The Kitts uranium deposit (in Labrador, Gandhi, 1978), which contains pitchblende in an argillaceous sediment regionally metamorphosed to a greenschist amphibolite facies, provides some clue as to the effects of temperature and pressure 
conditions on what is assumed to have been a uraniferous black shale. The Kitts deposit is affected both by regional metamorphism and by a nearby intrusive gabbro which has produced a hornblende-hornfels facies containing andalusite. The latter serves as a pressure index mineral and is diagnostic of pressures less than 3 kilobars. The temperature range of the facies is commonly given as $350^{\circ}$ to $600^{\circ} \mathrm{C}$. The metamorphosed argillite varies predominantly from an andalusite-bearing to a garnet-bearing meta-argillite containing coarse porphyroblasts of the chiastolite variety of andalusite and almandine garnet. These minerals are set in a fine matrix of albite, quartz, amphibole, biotite, and minor microcline. Original pyrite has been transformed to pyrrhotite. $\mathrm{CO}_{2}$ and $\mathrm{H}_{2} \mathrm{O}$ are low, indicating loss of these components due to metamorphism. Dark grey graphitic, pyrrhotite-bearing beds and lenses form a small, variable part of the meta-argillite but are the most important hosts of uranium mineralization. Sillimanite is well developed in light-colored beds within the meta-argillite. 'Thin lenses rich in amphibole and magnetite are also observed. The host meta-argillite and the ore zone at the Kitts deposit are thickened due to folding, and discontinuities are frequent, probably due to deformation. Faulting of the ore zone is common but with small displacement on the order of a few tens of meters. Metamorphism has modified but not destroyed the original distribution of uranium along the host beds. Some local redistribution of uranium is noted along bedding planes, fold hinges, fractures, shears, and veins, with the mineralized fractures, shears, and veins extending into the rocks adjacent to the meta-argillite host unit. Calcite and quartz, and to a lesser extent pyrrhotite, also show local mobilization. The Kitts deposit, therefore, shows only local redistribution of uranium as a consequence of moderate temperature and pressure metamorphism. 
The meta-argillite itself is fine-grained and consists of varying amounts of albite, quartz, amphibole, pyroxene, biotite, chlorite, graphite, calcite, pyrrhotite, pyrite, and chalcopyrite. Graphite is present in the range of 1 to 2.5 percent, whereas pyrrhotite is present in amounts up to 10 percent. Interestingly, the ratio of graphite to pyrrhotitic sulfur is considerably lower at Kitts (1:5 to 1:2) than in the Swedish alum shale $(2: 1)$, indicating a much greater loss of carbon, probably due to metamorphism. The loss of carbon possibly accounts for the much higher tenor of uranium (about $0.15 \% \mathrm{U}_{3} \mathrm{O}_{8}$ ) at Kitts compared to Billingen (about $0.03 \% \mathrm{U}_{3} \mathrm{O}_{8}$ ). One important effect of metamorphism may therefore be a considerable reduction in carbon content of the shale and a concomitant substantial increase in uranium grade, thereby enhancing economic recoverability.

It is very probable that in low-grade metamorphic situations uranium will remain tied up with carbonaceous material in the black shale, even under circumstances that largely convert organic matter to graphite and pyrite to pyrrhotite. With increasing metamorphic intensity uranium tends to move into intersecting fractures, faults, and fold noses. An indication of the extent of uranium mobility may be obtained from the distribution of pyrrhotite (or pyrite) or other sulfide-forming metals normally incorporated along with uranium in the carbonaceous matter. If metals such as $\mathrm{Z} n$, $\mathrm{Cu}$, and $\mathrm{Pb}$, have been sweated out of the carbonaceous matter in discrete sulfide grains, such as sphalerite, chalcopyrite, and galena, either associated with pyrite or disseminated in the inorganic shale matrix leaving the graphite residue fairly devoid of these metals, uranium will probably have been redistributed too. If pyrrhotite, or pyrite, appears in veinlets or fractures peripheral to the black shale, uranium will probably have been similarly mobilized. If the iron sulfides are partially or largely replaced by magnetite, the oxidation potential will have increased sufficiently during 
metamorphism to cause probable removal of uranium in oxidizing fluids. Migration of uranium due to regional metamorphism may be restricted largely to the original host shale lithology, at least until high metamorphic intensity is achieved, probably because the fluids associated with metamorphism are insufficient to transport much uranium until a migmatization or anatectic stage is reached. Hence; mobilization of uranium during the non-granitizing stages of progressive regional metamorphism may be inconsequential.

Speculation concerning the ore-generating potential of granitization of organic sediments in the geosynclinal pile is beyond the scope of this report. Anatectic processes are known to form uranium ore bodies presumably by chemical remobilization of uranium from basement rocks with copious release of water during ultrametamorphism (e.g. Rossing). This must, therefore, be considered in evaluating the uranium potential of granites and related rocks intruded within mobile belts, particularly in geosynclinal areas containing an abundance of organic shales.

\section{EUXINIC SHALE FACIES OF THE APPALACHIAN FOLD BELT}

Euxinic facies containing uranium deposits have been recognized and described. only in a few areas of the world, the most prominent examples being the Swedish alum shales, the Chattanooga Shale, and the meta-argillites of the Kitts-Post Hill belt of Labrador. Of considerable interest also, largely because of their geochemical resemblance to the deposits mentioned above, are the uranium occurrences in the Permian Lodeve basin in southern France. The Lodeve district contains organic shales and siltstones interbedded with sandstones, and tuffs. The uranium is closely associated with the bituminous material in the shales which were deposited in a swampy, 
present, the uranium is believed to be volcanogenic.

Reefal limestones overlain by volcanic beds when retaining organic matter can be effective in reducing uranium liberated during volcanism or subsequent thereto, as has for example been suggested for Pena Blanca. A variety of argillaceous, arenaceous, and carbonate sediments containing organic matter are capable of hosting uranium deposits. The carbon content of some may not exceed a few percent in the present-day rock but was undoubtedly considerably higher prior to diagenesis and metamorphism. The environment of deposition of clastic rocks must have. involved bottom waters that were anoxic and sediments that were capable of sustaining sulfate-reducing bacteria. Such conditions inhibited benthic life, hence the sediments are usualty characterized by the absence of shelly fossils.

There appears to be no particular bathymetric connotation to black shale deposits. Many were laid down in shallow iwater, while others are of :deep-water origin.' Some are obviously associated with marine transgressions. Euxinic deposits extend from eugeosynclinal through miogeosynclinal into shelf environments. The organic content is highly variable. Depressions in continental platforms are usually $r$ icher in organic matter, as is the break in the continental slope, probably owing to organic material being washed off the platform.

The carbonaceous residues of organic limestones produced by a variety of reefforming organisms provide suitable conditions for uranium deposition, although there are no examples of significant uranium deposits with the possible exception of Pena Blanca. Marine limestones as a rule constitute. oxygen-ventilated deposits; but some are transitional types being blackish, fetid, and pyritiferous. Where carbonaceous limestones are associated with potential uranium source rocks such as volcanics, the possibilities for deposition of uranium should be examined. 
The Lower Paleozoic terrain of the Appalachian fold belt contains a multiplicity of euxinic strata, many of which are interbedded or associated with volcanic rocks. These pelitic facies appear to merit examination for their uranium potential on the basis of concepts presented in the preceding sections of this report: This section of the report is therefore optimistically devoted to providing information on the distribution of some organic shales which appear promising from descriptive lithologic data furnished in the literature. The literature search has been by no means exhaustive, therefore many additional unmentiuned localities of poesible interest may also be obvious to the informed reader.

The boundary between the contrasting Cambro-Ordovician carbonate platform sequence. and the clastic facies farther east in the northeastern United States is considered to be an abruptly descending slope that formed the eastern edge of the continent at that time, all the terrain to the east having been deep water, probably diversified by volcanic and non-volcanic island arcs (Rodgers, 1968). Hence it approximates the: hinge-line region of the Scandinavian Caledonides described by Gee (1972). The Cambro-Ordovician carbonate rocks constitute a vast sheet that is contemporaneous with pelitic deep-water deposits in the western part of the Appalachians. The carbonate sediments form a thick sequence of rocks along most of the western side of the Appalachians from Newfoundland to Alabama, ranging in age from Early Cambrian to Middle Ordovician. They are exposed in the Hudson and Champlain Valleys and in western Newfoundland. The rocks, which are many thousands of fert: thick, reat. on basal Cambrian clastics and grade upward and eastward from the top of the Middle Ordovician into basal parls of westward-advancing wedges nf black graptolitic shale. 
The carbonate sequence is interspersed at several levels with clastic material, with shale invading the Middle Cambrian and lowest Upper Cambrian in several areas. It can be followed a short distance eastward. into the metamorphic part of the Appalachian chain where it appears as marble.

The Cambro-Ordovician rocks in the metamorphic Appalachians are generally clastic, now occurring as schist, and contain volcanics, now largely greenstone or amphibolite, at certain stratigraphic levels. To the west, some of these clastics occur as less metamorphosed or unmetamorphosed facies in structural blocks. The shale and shaly limestone in these blocks are generally dark and contain pyrite suggesting relatively stagnant water. Fossils in the pelitic sequence suggest deposition in relatively deep, poorly aerated water. In the Ordovician strata, graptolites and a few other planktonic-type fossils predominate. With few possible exceptions the boundary between the carbonate and pelitic Cambro-Ordovician facies has not been observed, possibly because of its very abrupt nature due to rapid sloping to the west and possible normal faulting.

In New England, volcanic rocks become increasingly abundant eastward, with maximum development along the trend of the Bronson Hill anticlinorium and its extension through Maine. This belt may have been a valcanic island arc restricting circulation in the basin to the west between the arc and carbonate bank.

Strata of known Cambrian age crop out in New England and adjacent areas within two bands. One band lies within the Hudson and Champlain Valleys in the west. This has a sand-carbonate facies that grades to the east into shale. Part of this facies has been moved westward in thrust blocks onto the sand-carbonate shelf facies to form the Taconic klippe. The shelf facies, in turn, has been driven westward onto the Adirondack foreland. The other band lies to the east along the Atlantic coast. This is 
manifested by sporadic outcrops of a dominantly shale facies in eastern Massachusetts and Maine as well as in New Brunswick and Nova Scotia. Metamorphosed Cambrian strata also occur between these two bands in the central New England region which is mainly occupied by younger strata.

The sand-carbonate shelf facies, with subordinate shales, extends along the Champlain, Hudson, and Housatonic valleys into Duchess County, New York, where it is buried under Ordovician strata. Immediately to the east of this lies a dominantlyshale basin sequence containing some volcanics, now metamorphosed to phyllites, schists, greenstones and, locally, gneisses. Thrusting has obscured, for the most part, any transition, whether gradational or abrupt, between the shelf and basin sequences in this region.

The lithology and stratigraphy of the sedimentary units in the Taconic klippe are closely comparable with that in the basin sequence. The Taconic sequence is therefore interpreted as a transported remnant of the basin sequence. The Taconic region contains an extensive graywacke (Bomoseen Graywacke) which forms the lowest unit along the western margin of the klippe. This grades into a thick section of Rensselear Graywacke in Rensselear County, New York. This, in turn, grades up into purple and green argillites named Mettawee Slate containing Lower Cambrian fossils in an upper limestone unit. The Bomoseen Graywacke and Mettawep Slate comprise the Bull Formation. The latter is overlain by the West Castle Formation composcd of dark gray shales and llmestones.

At the top of the Cambrian unit in the Taconics lies the Hatch Hill formation which is essentially a black pyritic shale containing interbedded dolomitic sandstones. The sequence is equivalent to the Germantown Formation in Columbia County, New York. Both units contain graptolites identifiable with Upper Cambrian strata. Becau। 
of their euxinic nature, the black shales of these two formations warrant examination for uranium.

Also of possible interest in the eastern part of the Taconic klippe is the Brezee Phyllite composed of dark grey to black phyllite. Although earlier assigned to the allochthonous West Castleton Formation of Cambrian age, it has since been recognized as a distinct unit. It is considered equivalent to the Hoosac Formation, which lies on the east side of the Green Mountains and also bears examining.

In the Cambro-Ordovician sequence, the Poultney Slate extending south from Quebec, the Schagticoke and Deepkill. Shales in eastern New York, and the Germantown and Stuyvesant Falls Formation in the southern part of the Taconic area constitute graptolitic shale units. The Stowe Formation in northern Vermont includes volcanics and slates. Numerous Middle Ordovician strata throughout central New England, as well as parts of Quebec and New Brunswick contain volcanics. Thick sequences of rucks lylug stratigraphically beneath those of Middle Ordovician age in New Brunswick also contain volcanics.

The Giddings Brook Slice (Figure 18) of the lower Taconic allochthon in the vicinity of Granville, New York, contains outcrops of a number of the abnve-mentioned black shale units (Rowley, Kidd, and Delano, 1979): The allochthon, iteolf, comprises a sequence of predominantly deep-water argillaceous and subsidiary arenaceous and calcareous rocks of Cambrian and Cambrian to Middle Ordovician age that crop out in an elongate belt about $200 \mathrm{~km}$ long from the vicinity of Sudbury, Vermont to Poughkeepsie, New York, along the borders between New York and Vermont, Massachusetts and Connecticut. The rocks, now primarily slates, have undergone low-grade regional metamorphism with deformation increasing from west to east. The allochthon consists of six major thrust slices, one of which is the 


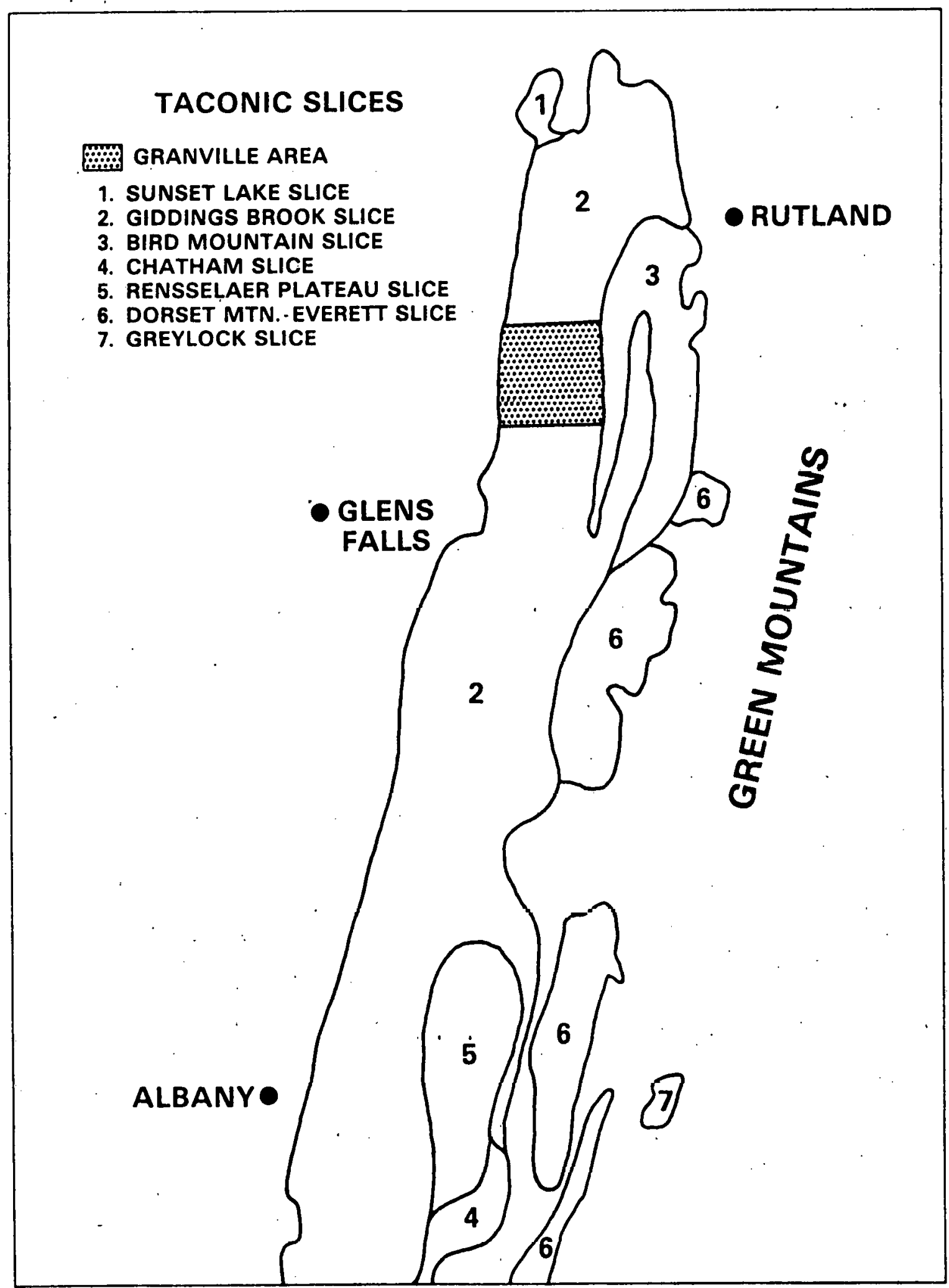

Figure 18. Giddings Brook Slice (after Rowley, Kidd, and Delano, 1979). 
Giddings Brook Slice in the northern part of the Taconics.

The black-slate-bearing units in the Giddings Brook Slice are identified as the Browns Pond, West Castleton, Hatch Hill, Poultney, and Mt. Merino Formations. These are most prominently exposed in the western part of the slice and have been described by Rowley, Kidd, and Delano (1979). The Browns Pond Formation, which is the stratigraphically lowest unit in the sequence, is a heterogeneous assemblage of limestone conglomerate and breccia, quartz wacke, and calcareous and quartz arenites, in a predominantly black slate matrix. The quartz wacke is set in a black slaty wacke matrix containing black phosphatic pebbles. The formation varies in thickness from 25 to 130 meters. The West Castleton Formation, which is usually included with the Hatch Hill Formation, is a black-fissile, often pyritiferous slate and gray limestone. Its thickness varies between 0 and 20 meters. The Hatch Hill Formation, which varies in thickness between 35 and 205 meters, is also characterized by black, fissile slate, often rusty and containing interbeds of dolomitic arenites. The Poultney Formation consists of the Crossroad Member and Dunbar Road Member, the latter being a fissile dark gray to black slate with interbedded thin silty limestones.' The formation contains black phosphatic pebble conglomerate, and measures between 70 and 210 meters thick. The Mt. Merino Formation varies between 25 and 70 meters in thickness. It consists of a lower banded chert member and an upper black slate member. The Lower Chert Member consists of black banded chert with minor interlayered black slate both of which are often pyritiferous. The upper slate (Stoddard Road Member) is a very distinctive, coal-black, rusty-weathering, silty, graptolitic slate.

Phosphatic clasts are chiefly characteristic of only the Cambrian part of the Taconic stratigraphy, occurring in several horizons including the basal Hatch Hill 
(West Castleton) Formation and the upper Poultney Formation carbonates.

The stratigraphic section in the Giddings Brook Slice in the Granville area represents a time interval from late early Cambrian to late middle Ordovician, a period of perhaps about $110 \mathrm{~m} \cdot \mathrm{y}$. It is however only about 600 meters thick on the average. Allowing for tectonic thinning, Rowley, Kidd, and Delano (1979) estimate an original thickness of about 2,000 meters, or an average deposition rate of about 20 meters/m. y. The depositional environment is therefore depicted as a "starved" continental rise adjoining a carbonate shelf, and resembles perhaps the Caledonide shelf/geosyncline interface, or hinge zone, described by Gee (1972).

Southwestern Maine is underlain by a diverse eugeosynclinal sequence of metasedimentary and metavolcanic rocks of Ordovician to Early Devonian ( ?) age (Hussey, 1968). The Ordovician Rye Formation in this region contains graphitic phyllites in a metavolcanic sequence 1,000 to 2,000 feet thick. This unit correlates with the Ammonoosuc Volcanics of western New Hampshire. Graphitic phyllite is also present in rusty-weathering sulfide-bearing quartz-muscovite schist of the Lower Devonian Towow Formation (Shapleigh Group) which crops out in the center of the Lebanon syncline. Within the Silurian-Devonian Casco Bay Group, sulfidic schists of the volcanic Cushing Formation (Granodiorite), black sulfidic graphitio schist and phyllite of the Diamond Island Formation, sulfidic schists of the Scarboro and.Jewell Formations warrant inspection. The Cushing Formation consists of a varied assemblage of metasediments (including pelltes) and felsic and mafic metavolcanics. The Diamond Is land Formation is coal black in color and exhibits strong iron-oxide and sulfate staining. It is lithologically the most distinctive unit in the Casco Bay Group and is possibly the most interesting on the basis of its apparent euxinic character as a possible uranium host rock. It is succeeded upwards by a 
conformable sequence of sulfidic (and non-sulfidic) metapelites, including the Jewell Formation.

The lower part of the Lower Devonian Rindgemere Formation (Shapleigh Group) contains rusty-weathering sulfide-bearing schists and gneisses. Extensive migmatization and intrusion by pegmatites make this unit of especial interest. The Rindgemere Formation consists of three lithologic types: (1) grey-brown, medium-grained mica schist and migmatite, (2) rusty-weathering, sulfide-bearing quartz-mica schist, and (3) green-grey, bedded, lime silicate granofels, (Gilman, 1970). The sulfide-bearing sr.hist. is easily recognized in outcrop by its rusty or sometimes yellow and black weathering surface. The sulfide content is given at 2 to 5 percent. Rusty units are also occasionally found within the schist-migmatite unit. The rusty quartz-mica schist occurs in a northwest-trending belt passing between Sawyer Mountain and Hosac Mountain in York County, Maine, and is known to extend as far north as Mt. Cutler (Kezar Falls quadrangle). It appears to be a rather thin unit (few hundred feet) within the Rindgemere Formation. The Towow Formation can be correlated with the upper Littleton Formation in east-central Maine and with pelites and rusty units in the Dixfield area.

In western Maino, several shale (slate) units in the Grand Lake area (Figure 19), Aroostook, Hancock, Penobscot, and Washington Counties appear to contain euxinic facies. The bedrock geology of the region has been described by Larrabee, Spencer, and Swift (1965). Magnetite-bearing black slates interbedded with tuffaceous metasiltstone occur in the Silurian Daggett Ridge Formation and outcrop in the Danforth quadrangle. Black carbonaceous graptolite-bearing slate in a sequence of Ordovician slate, metachert, and rhyolitic metatuff is found on the north and northwest slopes 


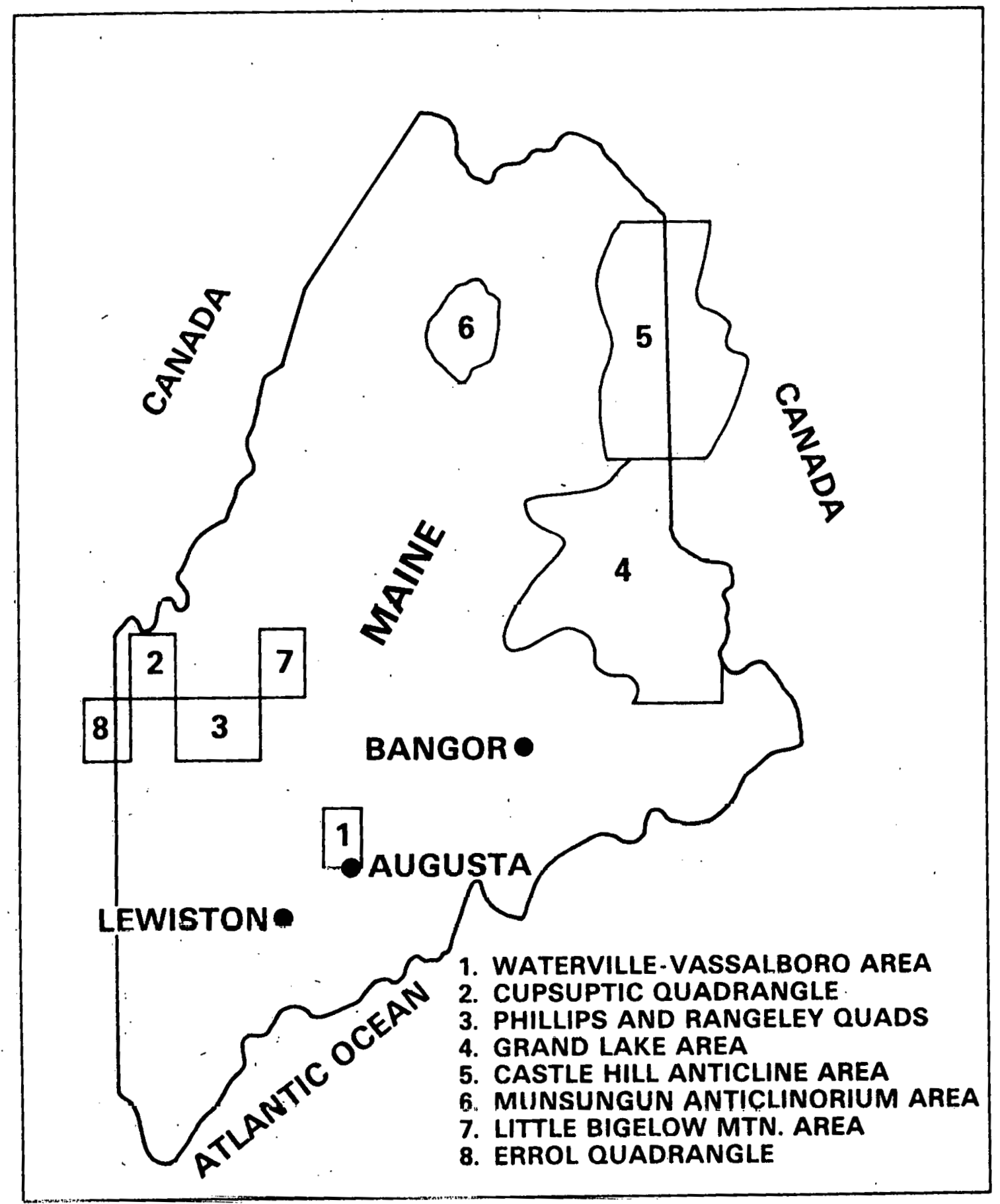

Figure 19. Index map of various black shale localities. 
of Snow Mountain in the Danforth quadrangle. Dark grey to black slates occur in the Ordovician Charlotte Group in the Big Lake quadrangle.

The "Snow Mountain" slate can also be seen on the east slope of Stetson Mountain (old lumber road). It is best exposed in a roadcut 1.5 miles northwest of Danforth along the road to South Bancroft. The black slate, silicified.metatuff, and metachert underlie most north-trending ridges. They are also present on Tolman Hill, Gates Hill and elsewhere between Tolman School and Almanac Mountain in the Springfield quadrangle. Pyrite has been observed throughout the length of the unit. A considerable thickness of soft black slate and metasiltstone underlies the "Snow Mountain" slate in swampy areas.

Thin lenses of black pyritiferous slate occur in the Silurian ( ? ) Kellyland Formation which is composed of interbedded sericitic pale-grey metasiltstone, arenaceous metasiltstone, argillaceous metasandstone, quartzite, and dark gray slate. The largest outcrop is at Grand Falls of the St. Croix River near Kellyland, Maine. The Daggett Ridge Formation in the Grand Lake area contains lenses of magnetite-bearing black slate and metasiltstone up to 70 feet thick interbedded with chloritic argillaceous quartzite, quartzite metaconglomerate, and grey and green slate. The black slates crop out 2 miles northeast of Bancroft in the eastern part of the Wytopitlik quadrangle, and are present in parts of the Danforth and nearby quadrangles. The ryolitic metatuff occurs in lenses along Baskahegan Stream near Bouth Bancroft in the Danforth quadrangle. The formation is well cxposed over a distance of 8,000 feet on Daggett Ridge and Jimmy Mountain in the Danforth quadrangle: Northeastern Maine is under lain by Cambrian (? ) to Middle Devonian sedimentary and volcanic rocks that have locally been metamorphosed to greenschist facies. Volcanism occurred from Cambrian (? ) through Early Devonian time but was most 
intense in the Ordovician and Early Devonian. The geology and geologic history of the region have been summarized by Pavlides, Mencher, Naylor, and Boucot (1964). Black carbonaceous slates occur in late Middle Ordovician rocks to the south and east of Houlton, interbedded with green phyllite. Carbonaceous mudstone interbedded with sandstone conformably over lies Devonian rocks on the north and south side of the Pennington anticline in the vicinity of Winterville. Small areas of Ordovician rocks contain graptolitic carbonaceous pelites on the southeast side of the AroostookMatapedia anticlinorium.

In the Shin Pond and Stacyville quadrangles (Neuman, 1967) in Penobscot County, Maine, dark grey carbonaceous slates occur within the Early Cambrian ( ? ) Grand Pitch Formation. The formation consists of grey, green, and red slate and siltstone, quartzite, and lesser amounts of graywacke and tuff. Exposures are virtually continuous along the East Branch of the Penobscot River from Grand Pitch to Bowlin Falls and are also well developed in Bowlin Bronk to the east and at Shin Falls of Shin Brook and the Seboeis River from the Grand Lake Road bridge to Grand Pitch. Dark grey slate interbedded with tuff beds 1 to 6 feet thick can be seen in the lower part of David Brook and on the shore of the Seboeis River opposite Gagnon Flats. Lithologic relationships of the Wassataquoik Chert in the Shin Pond-Stacyville quadrangles area are of especial interest, inasmuch as they resemble in descriptive aspect the lithology of the uraniferous Kitts area in the Kaipokok Bay-Big River r.glun, Labrador. The Kitts uranium deposits, described in an earlier section of this report, occur in graphitic meta-argillites (black shales) associated with cherts and volcanics, an association that is not uncommon in marine basins. Uranium in these deposits is att tributed to chemical reduction in the euxinic shale facies. The Wassataquoik Chert in the Shin Pond and Stacyville quadrangles is interbedded with 
felsic volcanic rocks and contains carbonaceous shaly beds at least 5 feet thick. In light of this similarity, the black shales should be considered potentially favorable for uranium.

Exposures of the Wassataquoik Chert are found about 1 mile northwest from the mouth of Wassataquoik Stream near the middle of the Stacyville quadrangle, which is the type locality. From Wassataquoik Stream, chert is continuously exposed southward on the ridge leading to Hunt Mountain, where it is in contact with volcanic rocks. Carbonaceous beds are exposed in the northernmost outcrop area about 1 mile south of Lower Shin Pond, together with thin-bedded chert and felsic tuff. They are also present along the Seboeis River and at several places to the north. More detailed information is aviallable in Neuman's paper (1967).

Late Silurian limestone, siltstone, and volcanic sequences in the Shin PondStacyville area are also of interest. Silty organic limestone, in a lens as much as 300 feet thick, underlies tuffaceous volcanic rocks in the nor theast corner of the Shin Pond quadrangle where it can be traced for about 1 mile. Haif or more of the limestone consists of colonial organisms. The occurrence here of a reduzate calcareous environment underlying volcanic beds is suggestive of the uranium environment of the Pena Blanca distriot in Mexicn, which is described in an earlier section of this paper. Reefal limestones are prominent in the general region and warrant investigation to ascertain their relationship to volcanic beds, as for example around the southern and eastern shore of Marble Pond.

Most of the southeastern half of the Stacyville quadrangle is underlain by slate, sandstone, and conglomerate of the Allsbury Formation. Ten bands of black slates have been identified in this formation in the Island Falls quadrangle, but the slate appears to be less abundant in the Stacyville quadrangle. 
Slate and siltstone interbeds form a part of a fault complex bordering the Allsbury Formation on the west. The complex contains conglomerate, sandstone, and patches of limestone and tuff breccia. The northern fault block contains one bed of dark grey carbonaceous slate about 50 feet thick traceable for about 1-1/2 miles from just east of Shin Pond Road southwestward towards Sucker Brook

The Cupsuptic quadrangle (Figure 19) in west-central Maine (Harwood and Berry, 1967) contains a late Middle Ordovician eugeosynclinal slate, graywacke, and greenstone sequence that includes graptolite-bearing black slate. The volcanic greenstone occurs adjacent to and interfingers laterally with beds of black slate which are highly fissile and pyritic and contain minor dark-grey sulfidic quartzite beds. Above the greenstone-slate unit in the southeast part of the quadrangle lies a black slate unit containing calcareous lithic graywacke, dark-grey sulfidic quartzite and minor greenstone. Typical exposures are found on the low hills northwest of Kamankeag Pond, in Kamankeag Brook east of the Oxford-Franklin County line, and on the prominent ridges at the north end of Ephraim Ridge. The contact between the blackslate unit and underlying greenstone is believed to be gradational. The maximum outcrop width of the black-slate unit within the quadrangle is 6,500 feet and its thickness is about 6,000 feet. The Middle Ordovician Partridge Formation, which has been mapped to within 20 miles of the Cupsuptic quadrangle, is considered correlative with the black slate unit, and the similarly mapped Amonoosuc Volcanics are probably correlative with the greonotone and slale unit.

The Dixville Formation, exposed in the northern half of the Cupsuptic quadrangle, is composed of a lower section consisting of rusty-weallier Ing black phyllite overlain by graywacke. The phyllite contains local greenstone lenses several hundreds of feet thick. 
In the Phillips and Rangeley quandrangles (Figure 19) in western Maine darkgrey sulfidic slate and phyllite occur within the graywacke member of the Quimby Formation (Moench, 1968). The graywacke member, which is about 1,000 feet thick, is composed of interbedded metagraywacke, conglomeratic graywacke, and subordinate amounts of metashale and felsic volcanic rocks. The sequence is of Late Ordovician (?) age and overlies the Dixville Formation. The base of the graywacke member rests on sulfidic metashale and metagraywacke of the Dixville. The shale member of the Quimby Formation overlies the metagraywacke. It is about 2,000 feet thick and consists predominantly of rusty-weathering cyclically interbedded medium-grey to black metashale and subordinate amounts of metagraywacke. The metashale is variably-carbonaceous slate, phyllite, or schist. Sulfide minerals, mostly pyrrhotite or pyrite, are nearly ubiquitous in the metashale, but they vary in abundance. The upper part of the rocks are particularly sulfide-rich in the Rangeley area and the Brimstone Mountain anticline. Distinctive beds of dense black sulfidic carbonaceous calcareous metasiltstone less than an inch to a few inches thick are common in the upper part of the shale member. A ten-foot-thick bed of probable felsic metavolcanic rock is present in the upper sulfide-rich zone of the shale member.

The Quimby Formation is a turbidite-shale sequence deposited in a euxinic. marine environment. The shaly rocks are grey and variably carbonaceous and sulfidic. The interbedded coarser clastic rocks have characteristics of turbidity-flow deposits, such as poor sorting of immature clastic material and graded bedding. Felsic volcanic rocks have been identified in the formation only in several outcrops but are assumed to be more abundant. The formation is thought to have been widespread in New England prior to the Taconic disturbance but has since been edroded from much of the region. Part of the Middle Ordovician to Lower Silurian Carys 
Mills Formation, exposed in northeastern Maine about 180 to 200 miles northeast of Rangeley, may be equivalent to the Quimby Formation, probably having been deposited in the same sedimentary trough.

In northeastern Maine, unnamed Ordovician rocks of the Castle Hill anticline area (Figure 19) near Presque Isle consist of silicic and intermediate volcanics, black chert, argillite, and black shale and slate, the latter occurring near the top of the unit which totals about 3,000 to 4,000 feet in thickness (Pavlides, 1968). In the Howe Brook quadrangle about 10 miles west of Monticello, the black chert contains carbonaceous argillite partings. East of Hodgdon and at Hovey Hill, scattered exposures of probable Ordovician to Early Silurian age include dark-grey to black slates and green phyllite. The Silurian Smyrna Mills Formation near Hodgdon contains black carbonaceous and pyritic slate. The formation outcrops from about Oakfield eastward to the international border near Houlton. It consists dominantly of quartzite, siltstone, and slate with local lenses of ferruginous manganese deposits and red and maroon slate and siltstone, the slate occurring chiefly in the lower part.

The : Boundary Mountains antlclinorium in northern New Hampshire and northwestern Maine contains carbonaceous phyllites and schists that make up the lower part of the Cambrian or Ordovician Aziscohos Formation (Green and Gludotti, 1968). The Aziscohos may be correlative with the Stowe and possibly Ottauquechee Formations in north-central Vermont where they lie on the east limb of the Green Mountain-Sutton Mountain anticlinorium. Above the Aziscohos is the Albee Formation, and above this lies the Dixville Formation which consists of carbonaceous slate, phyllite, schist, and quartzite as well as metavolcanic greenstone and amphibolite. The latter formation is estimated to be between 5,000 and 9,000 feet thick in 
the area and is intensely folded. The Lower Devonian Kidderville Formation in this region consists in part of felsic metavolcanic rocks interbedded locally with carbonaceous phyllite and schist.

Approximately 90 percent of the Aziscohos Formation is composed of micaceous schists and phyllites much of which are grey or black owing to the presence of fine-. grained, opaque, carbonaceous material (Green, 1964). The carbonaceous part of the formation is most likely a transgressive facies. Analyses show up to several percent carbon. The Albee Formation which overlies the Aziscohos consists of phyllites, schists, and micaceous quartzites. Lenses of grey to black, carbonaceous phyllites are widely scattered in the upper part of the formation, but these may be downfolds of the overlying Dixville Formation. The contact between the Albee and Dixville Formations is defined by initial occurrences of dark-grey to black schists, phyllites, and quartzites above the typically greenish rocks in the upper part of the Albee Formation. The Dixville is grey and carbonaceous and develops rusty outcrops due to weathering of iron sulfides. Exposures of this formation are abundant in the township of Dixville, New Hampshire, in both the Errol (Figure 19) and Dixville quadrangles, and are readily accessible (1964) in roadcuts along New Hampshire Route 26 in the vicinity of Dixville Notch in Dixville quadrangle and in the town of Millsfield; Errol quadrangle.

In the northwest corner of the Errol quadrangle, the oldest member of the Dixville Formation, i.e. the Dixie Brook Member consisting of grey to black slates, phyllites, and schists and black quartzites, is succeeded to the northwest by a band of felsic metavolcanic rocks, followed by a mixed sequence of carbonaceous phyllite, micaceous quartzite, and both felsic and mafic metavolcanics. The carbonaceous, 
pyritic Dixie Brook Member is well exposed in Dixie Brook, South Valley Brook, Swift Diamond River, and on Blue Ridge and Signal Mountain. The unit is estimated to be about 2,000 feet thick. Regional correlations for the formations in the Errol quadrangle are given by Green (1964). These would be of importance if investigation indicated the carbonaceous beds of the quadrangle to be of interest for uranium.

The Waterville-Vassalboro area (Figure 19) in south-central Maine is also of interest. It covers parts of the Augusta, Norridgewock, Waterville, and Vassalboro quadrangles and has been described by Osberg (1968). Black shale lithologies are found in several formations in the area. A thin black phyllite occurs at the top of the Silurian Mayflower Hill Formation and has been used to delineate the contact with the overlying Silurian Waterville Formation. Within the unit, black phyllite also forms a bed up to 100 to 200 feet thick. Outcrops of the black graphitic phyllite are commonly heavily coated with limonite and manganese minerals. Quartz and muscovite are the dominant minerals, but graphite, intergrown with the muscovite, and pyrrhotite are common. The Waterville Formation is essentially a pelite and limestone unit, but includes inlerbedued quarl's wacke. It cunslsts of an eastern and western facies, divided by exposures of the Mayflower Hill Formation. The eastern facies is dominantly thinly laminated phyllite split into two horizons by a 300-foot section of limestone beneath which lies a bed of black phyllite. The contact of the Waterville Formation with the overlying Devonian or Silurian Vassalboro Formatilon consists of local black phyllite ranging from 0 to 100 feet thick. The entire formation may be as much as 3,000 feet thick. In addition to the contact unit, two additional dark phyllite beds occur within the Vassalboro Formation. These are exposed dịcontinuously in the area about 0.3 miles east of Vassalboro, Graphite makes up about 10 percent and pyrrhotite 3 percent of the phyllite which is chiefly quartz and 
muscovite. Pyrrhotite and graphite are also generally common in the dark grey phyllite of the Vassalboro Formation, with the graphite being disseminated throughout the rock and pyrrhotite being both scattered and locally concentrated in lensshaped aggregates.

The Cambrian (?) Chase Brook Formation in the southern end of the Musungun anticlinorium, Maine, (Figure 19) contains carbonaceous black slate alternating in one-fourth to one-inch thick beds with grey slate (Hall, 1970). Masses of pyrite up to two inches in diameter are associated with these beds in the noses of small drag folds. Outcrops of the formation are found in the Spider Lake quadrangle along Chase Brook from a point about 300 yards to a point about one mile from its mouth in Chase Lake. The formation is also exposed in the Mooseleuk Lake quadrangle approximately one-third of a mile southwest of Mooseleuk Lake and in the Millinocket Lake quadrangle along the shores of Little Munsungun Lake and along Munsungun Stream as far downstream as Munsungun Falls. The Chase Brook Formation may be correlative with the Ottauquechee Formation in north-central Vermont and also resembles the lower unit of the Aziscohos Formation in the Errol quadrangle of Maine and New Hampshire.

In this samc rogion, carbonaceous chert and slate are interbedded with basalt, dolerite, rhyolite, and rhyolitic tuffs of the Middle Ordovician Bluffer Pond Formation. The most easily accessible exposures of chert and slate are located along the main Great Northern Paper Company road (1970) from about three-fourths of a mile to about three miles north of Pillsbury Pond. The formation is estimated to be 4,000 feet thick. The black chert and slate are locally graphitic and pyritic. 'Ihe Bluffer Pond is considered correlative with the greenstone, slates, and lower part of the black slate unit of the Dixville Formation in the Cupsuptic area of Maine. 
The Blind Brook Formation in the Munsungun anticlinorium consists predominantly of dark grey pyritiferous slates with minor interbedded tuff and tuffaceous slate. A well-exposed section is seen in Blind Brook in the Mooseleuk Lake quadrangle on the south side of the main Great Northern Paper Company road (1970) approximately 250 yards east of its crossing with Blind Brook. Approximately 6,000 to 7,000 feet of exposed formation is reported, which may include structurally: repeated sections. It is also present in the Spider Lake quadrangle. on the north limb of the anticlinorium east of the Munsungun Lake fault. The formation is composed of medium grey to dark grey, very thinly bedded graptolitic slate containing pyrite in discrete one-eighth to one-fourth inch thick laminae. An upper Middle Ordovician age has been assigned to it, and it is believed to be correlative with the Partridge Formation of New Hampshire and with some of the upper part of the black slate unit of the Dixville Formation. Of possible additional interest in the Munsungun anticlinorium area is an unnamed Siluro-Devonian reefal coralline limestone that rests uncomformahly on the Chase Brook Formation. The limestone is found on the north shore of Indian Pond and on the southwest shore of Chamberlain Lake. Green andesitic volcanics are intarbnddcd locally with the limestone and associated red siltstone and grey calcarinite.

Several. sedimentary units of the Little Bigelow Mountain area (Figure 19) in western Maine are noteworthy. The geology of this area is described by Boone (1973). The Silurian (?) Smalls Falls Formation is of possible interest as a reducing euxinic facies, consisting of black phyllite and dark grey to black well-cleaved metasiltstone. Both units are sulfide bearing and develop rusty weathered surfaces. Pyrrhotite and graphite make up one to two percent of the beds. Graphite is distributed evenly with slight variation from bed to bed, whereas pyrrhotite occurs both as fine disseminated grains and as porphyroblastic lenses which vary in concentration from bed to bed ove: 
a thickness of centimeters to a few meters. The formation is estimated to be about 1,500 feet thick. It crops out in two belts. The principal belt is about $1-1 / 2$ miles wide and extends from the eastern contact of the Lexington batholith to and across the Kennebec River in the central part of the Bingham quadrangle. It is best observed on the southeast side of Hutchins Hill and on steep knobs east of Spruce Pond and north of Witham Brook.

Also of possible interest in this area is the upper member of the Lower Devonian (?) Carrabassett Formation. This horizon is a lithic assemblage of thinly-layered calc-silicate rock, biotite schist, actinolite schist, and muscovite-biotite schist. The schistose rocks are pyritiferous, friable, and locally graphitic. The calc-silicate units are generally not as pyritiferous or graphitic as the more pelitic rocks. The pervasive distribution of pyrite is characteristic of this member. Where graphite is not abundant, the schist is violet-grey to reddish violet on fresh surfaces. The type localities of the upper member are:.(1) east valley wall of the Carrabassett River, 0.6 mile at 102 degrees from Spring Farm, where it is exposed in a fairly continuous section from 1,300 to 1,400 feet elevation in a gully; (2) in the upper part of Poplar Brook, 1,450 to 1,600 feet elevation; (3) on the west side of the main ridge of Little Poplar Mountain, at 1,800 and 1, you feet elevation and 290 to 309 degrees from the summit, respectively; and (4) on Cold Brook, from its confluence with Huston Brook to 1,330. feet elevation. The entire Carrabassett Formation is probably not thicker than 5,200 feet of which the upper member makes up about 200 feet.

A considerable number of additional individual papers comprising the voluminous literature on the New England Appalachian region present detailed information on. euxinic sedimentary units in the geosyncline and on the major north and northeast- 
trending structural units within the geosyncline, namely the Green Mountain anticlinorium, Connecticut Valley synclinorium, Bronson Hill anticlinorium, and the Merrimack synclinorium. Correlation of many of the black shale (slate or phyllite) units is possible on the basis of graptolitic and litholigic characteristics, thus facilitating recognition of the geographic distribution of these units as well as any exploratory investigations. No attempt has, however, been made to provide such' information in the preparation of this paper because of the considerable additional time and effort that would have been involved. It could be done if $\mathrm{f}$ ield investigations. indicate that such information would be useful.

The selection of referenced literature has been to some extent dependent on the immediate availability of papers on the geology of the region. Much additinnal puhlished and unpublished data are available. An expanded and more intense study of the distribution of graphitic and sulfidic facies could be undertaken if field studies indicate the advisability of such a task based on radiometric observations or other judgements.

Ono additional area of New Enyland that is of interest for possible occurrences of uraniferous black-shale facies is the Avalonian region of Massachusetts and Rhode Island (Figure 4). It is described in a separate (fôllowing) section because, although geographically associated with the Appalachian fold belt, it is a structurally and stratigraphically distinct lithology.

\section{AVALONIAN BLACK SHALES}

Eurly Paleozolc sediments along the most easterly flank of the Appalachlan fold belt in Massachusetts and Rhode Island comprise part of what is known as the Avalon belt, a zone, including late Precambrian rocks, that extends southward along a line 
from southern New Brunswick, Cape Breton Island, and the Avalon Peninsula of eastern Newfoundland (Figure 5). The belt is bordered on the oceanward side by a great thickness of folded Ordovician and possibly Cambrian sediments, including shale and limestone, that appear not to be an integral part of the Appalachian geosyncline fold-belt. Before late Paleozoic closure of tapetus, the belt may have been part of a sedimentary sequence, on the eastern side of the ocean, which is believed to have been welded to the North American continent during closure of the protoAtlantic. The sediments contain fossils of European aspect and have geologic similarities to rocks on the eastern side of the Atlantic that at one time formed a major early Paleozoic mountain system.

In Newfoundland, the Avalonian rocks are known to contain Middle and Upper Cambrian black shales (McCartney, 1969). The Middle Cambrian sediments are . composed largely of dull grey-green slate in the lower two-thirds and poorly-bedded dark-grey slate and minor limestone in the upper third ranging in thickness from about 245 - 550 feet. This sequence is overlain by fossiliferous dark grey to black slate and shale, and minor limestone interbedded locally with pillow-lava flows or equivalent tuff or breccia. The slate and volcanics are each up to about 100 feet thick. The Upper Cambrian beds are sparsely fossllifeious and consist of blaok, locally pyritic, slate interbedded with light-grey shale (Elliott Cove Group). These beds contain Peltura and Olenus faunal zones, which are of especial interest because of the association of uranium with these zones in the Cambro-Ordovician black shales of Sweden.

Palmer (1980) has called to the writer's attention the fact that the Upper Cambrian faunas, and to some extent lithologies in the Avalonian belt, bear a striking resemblance to those in rocks of similar age in Scandinavia and Wales. The Avalonian 
sections are much thicker than in Scandinavia, but nevertheless constitute a predominantly black shale facies. According to Palmer (1980), Avalonia represents some kind of submerged volcanic arc complex of Precambrian age with Cambrian clastic sediments, largely lacking volcanics, deposited on top. The Avalonian section has much of the same trilobites as in Sweden but it does not rest on crystalline basement.

Because of the extensive distribution of Cambro-Ordovician black shales in Europe, where they are persistently uraniferous, the lithology of the Avalonian belt, which appears to be comparable in many respects, certainly deserves study for possible uranium host rocks. Investigation of this lithology in Now England, and in the Canadian provinces, would seem to be a worthwhile undertaking.

\section{EFFECTS OF GRANITIZATION AND INTRUSION IN THE APPALACHIAN FOLDBELT}

Felsic plutonic rocks widely permeate the metamorphosed supracrustal rocks of the Appalachian foldbelt, both intruding and replacing them concordantly and discordantly. Some are relaled to development of the eugeosyncline while others post-date it. Still others are part of island-arc or microcontinent segments welded to the ancestral Appalachians during the interval of tectonic closure of the northern AppatachianCalèdonian oceàn (Iapetus):

A number of these intrusives are geochronologically related to granitic rocks of western Europe (France, Iberia) that contain productive uranium deposits. The intrusives, known to contain uranium, have been attributed by Bodidette (1977), to urugenesls caused by progressive interplate collision. They originate from eugeosynclinal sedimentary and/or volcanic rocks as a consequence of partial melting during metamorphism and are rooted in migmatites associated with an island-arc segment 
welded onto the ancestral Appalachians after the Taconian orogeny. They occur as two-mica granite (Concord Granite) that was extracted from the migmatite during anatexis and mobilized in westward-intruding sheets. Preconcentration of the uranium is presumed to have occurred in the migmatite and, supposedly, in the original sediments. The model proposed by Boudette (1977) has some resemblance to the model presented for the Rossing deposit, and both the granite and migmatite are suggested as potentlal ore terrane.

Although the uranium potential of the Concord Granite remains to be demonstrated, the genetic model proposed for the anatectically derived uranium host rock;: i.e. the Concord Granite, encourages examination of the geosynclinal sediments of the Appalachian fold belt for uranium, particularly if it can be shown that the sutured island arc segment contained euxinic sediments that are an extension of or grade into the deep-water facies of the eastern part of the Appalachians.

Obviously, many of the Appalachian foldbelt intrusives, both related and unrelated to granitization caused by subduction, provided local sources of heat and heated fluids that created thermal aureoles in the surrounding metasediments. Invasion of uraniferous shales by these intrusives may have created contact metamorphic aureoles in whioh uranium was reworked into pitohblendo veins. Invasion of non-uranifcrous organic shales by these intrusives may have resulted in localization of uranium, introduced in the granite, by the reducing action of the organic matter. It is noteworthy that ore deposits within contact metamorphic aureoles associated with granites invading shales rich in organic matter constitute a major part of Spain's uranium resources and are also prevalent in Portugal (OECD/IAEA, 1980).

The Concord Granite (Binary Granite) of New Hampshire locally intrudes the Devonian Littleton Formation often intricately as dikes and sills. Its distribution is 
shown on the geologic map of New Hampshire and is described by Billings (1980). The Littleton Formation is very widespread in New Hampshire and occupies a large area extending from Massachusetts to Maine (Billings, 1980). Its lithology is very complex, being originally composed chiefly of argillaceous and arenaceous sediments but also containing beds of volcanics, quartzites, and dolomites, all now metamorphosed. The most abundant rocks are dark-grey slate and dark-grey sandstone. The lowest 1,000 feet of the formation is entirely black slate. Above this is a zone of black slate and volcanics about 700 to 900 feet thick. Massive dark-grey sandstones make up the overlying 500 feet, whereas the uppermost 3,000 to 4,000 feet of the formation is dark-grey slate and dark-grey sandstone. Pyritiferous gneisses (originally shales) are widespread in some places, weathering to rusty-brown or jet-black surfaces. These also contain graphite. Pyrite ranges from 1 to 5 percent and graphite from a trace to 2 percent. These gneisses are associated with Concord Granite in the Bretton Woods area where they constitute potential uranium ore terrane on the basis of the contact aureole concept.

In summary, black pyritic and graphitlc shales have characteristic chemical properties that provide opportunities for uranium concentration in platform, intermediate and geosynclinal settings as well as in local environments of granitoid migmatization and intrusion.

\section{ACKNOWLEDGEMENTS}

The writer is indebted to several individuals for personally contributing infor mation that was helpful to the preparation of this report. Allison R. Palmer of the Geological Society of America provided useful observations on the Avalonian belt and David F. Strong of the Memorial University of Newfoundland furnished several papers 
of interest on uranium in Sweden.

The writer is also grateful to George Leney of the U. S. Department of Energy for some useful discussions of uranium occurrence in the Adirondack and New England regions during the early formative stage of this project; to S. Victoria Krusiewski of the U. S. Department of Energy for her assistance in obtaining geologic reference data; to William Chenoweth of the U.S. Department of Energy for his technical guidance; to the various staff of the technical library of the U. S. Geological Survey in Reston, Virginia, who graciously aided the writer in tracking down a number: of the papers referenced in this report; to R. E. Jacob of the Rhodes University in Grahamstown, South Africa, for obtaining and granting approval for use of a previously restricted publication on the Rossing deposit; to LaNi ta Bennett for her care in typing this report from a handwritten manuscript containing considerable terminology completely unfamiliar to her; and to Adisai Hemintranont for the drafting of the illustrations.

For discussion of limestone facies of the Lower Paleozoic shelf and geosyncline, thanks are due Gerald M. Friedman of the Rensselaer Polytechnic Institute and to Robert B. Neuman. 
Adams, J. W., Arengi, J. T., and Parrish, I. S. 1980, Uranium- and thoriumbearing peymatites of the United States; U. S. Department of Energy, Grand Junction Office, Grand Junction, Colorado, Report No. GJBX-166, (80).

Adler, H. H., 1977, Geochemical factors contributing to uranium concentration in alkalic igneous rocks; in recognition and evaluation of uraniferous areas; Proc., Intl. Atomic Energy Agency, Vienna, 35-43.

Alling, H. L., 1917 (1918), The Adirondack graphite deposits; N. Y. State Mus. Bull. 199.

Andersson, A., 1971, Petrographic and chemical study of the Lower Ordovician uranium-bearing sedimentary unit at Tasjo Lake; Geologiska Foreningen i Stockholm Forhand lingar, 93, 117-135.

Appleyard, E. C., 1965, The Grenville Province and its tectonic significance-a discussion; Geol. Assoc. Canada, Proc., 16, 51-57.

Armands, G., 1970, A uranium-bearing layer from the Lower Ordovician, Sweden; Geologiska Foreningen i Stockholm Forhandlingar, 92, part 4, 481-490.

Armands, G., 1972, Geochemical studies of uranium, molybdenum, and vanadium In a Swedish álum shale; Stockholm Contr. in Geol., 27, no. 1, 148 p. Baldwin, A. B., 1970, Uranium and thorium necurrences on the north shore of the Gulf of St. Lawrence; Can. Inst. Min. Met. Bull. 63, 699:-707.

Berning, J., Cooke, R, , Hiemstra, S. A., and Hoffman, U., 1976; The Rossing uranlum deposit, South West Africa; Econ. Geol., 71, 351-368.

Billings, M. P., 1980; The geology of New Hampshire, Part II. Bedrock geology: New Hamp. Dept. Res. and Econ, Dev., reprinter, 200 p.

Boone, G. M., 1973, Metamorphic stratigraphy, petrology, and structural geology of the Little Bigelow Mountain map area, western Maine; Maine Guol. Survcy Lull. 24, 136 p.

Boudette, E. L., 1977, Two-mica granite and uranium potential in the northern Appaląchian orogen of Now England; U. S. Geol. Survey Circ. 753, 23-24.

Breger, I. A. and Brown, A., 1963, Distribution and, types of organic matter * in a barred marine basin;. Trans. N. Y. Acad. Sci. Ser II, 25, 741-755. 
Brongersma-Sanders, M., 1969, Permian wind and the occurrence of fish and metals in the Kupferschiefer and Marl Slate; 15th Inter-Univ. Geol. Cong., Univ. Leicester, Proc., 61-71.

Brown, J. S., and Engel, A. E. J., 1956, Revision: of Grenville stratigraphy and structure in the Balmat-Edwards district, northwest Adirondacks, New York; Bull. Geol. Soc. America, 67, 1599-1622.

Buddington, A. F., and Leonard, B. F., 1962, Regional geology of the St. Lawrence County magnetite district, Northwest Adirondacks, New York: U. S. Geol. Survey Prof. Paper 376, 145 p.

Buddington, A. F., Jensen, M. L., and Mauger, R. L., Sulfur isotopes and origin of northwest Adirondack sulfide deposits; in Igneous and Metamorphic Geology, Geol. Soc. Am. Memoir 115, 423-451.

Calvert, S. E., and Price, N. B., 1970, Minor metal contents of recent organicrich sediments of South West Africa; Nature, 227, 593-595.

Carl, J. D. and Van Diver, B. B., 1975, Precambrian Grenville alaskite bodies as ash-flow tuffs, northwest Adirondacks, New York; Geol. Soc. Am. Bull., $86,169 l-1707$.

Cobb, J. C. and Kulp, J. I., 1961, Isotopic geochemistry of uranium and lead in the Swedish kolm and its associated shale; Geochim. et Cosmochim, Acta, 24, 226-243.

Cook, P. J. and McElhenney, M. W., 1979, A reevaluation of the spatial and temporal distribution of sedimentary phosphate deposits in the light of plate tectonics; Econ. Geol., 74, 315-330.

Davidson, C. F., 1961, The kolm deposits of Sweden; Mining Mag., 105, 201-207.

Engel, A. E. J. and Engel, C. G., 1953 a, Grenville Series in the northwest Adirondack Mountains, New York: Part I: General features of the Grenville Series; Geol. Soc. Am., Bull., 64, 1013-1048.

Engel, A. E. J. and Engel, C. G., 1953 b, Grenville Series in the northwest Adirondack Mountains, New York: Part II: Origin and metamorphism of the major paragneise; Gcol. Soc. Am., Bull., 64, 1049-1098. 
Fisher, D. E. and Bostrom, K., 1969, Uranium-rich sediments on the East Pacific Rise; Nature, 224, 64-65.

Foose, M. P. and Carl, J. D., 1977, Setting of alaskite bodies in the northwest Adirondacks, New York; Geology, 5, 77-80.

Frietsch, R., Papunen, H., and Vokes, F. M., 1979, The ore deposits in Finland, Norway, and Sweden--a review; Econ. Geol., 74, 975-1001.

Gandhi, S. S., 1978, Geological setting and genetic aspects of uranium occurrences in the Kaipokok Bay-Big River area, Labrador; Econ. Geol., 73, 1492-1522.

Gee, D., 1972, The regional geological context of the Tasjo uranium project, Caledonian Front, central Sweden; Avhandlingar Och Uppsatser, Arsbok 66 Nr. 2, Ser. C, Nr. 671.

Gilman, R. A., 1970, Structural and stratigraphic studies in the Sawyer Mountain area, York County, Maine; in Shorter Contributions to Maine Geology, Maine Geol. Survey Bull. 23, 53-57.

Gittins, J., 1967, Nepheline rocks and petrological problems of the HaliburtonBancroft area; Geol. Assoc. Canada Guidebook, 31-57.

Goodell, P. C., Trentham, R. C., and Carraway, K., 1978, Geologic setting of the Pena Blanca uranium deposits, Chihuahua, Mexico; in Formation of Uranium Ures By Diagenesis of Volcanic Sediments, U. S. Dept. of Energy, Repuirt Nu. GJBX-22 (79).

Grauch, R. E. and Zarinski, K., 1976, Generalized descriptions of uranium-bearing veins, pegmatites, and disseminations in non-sedimentary rocks, eastern United States; U. S. Geol. Survey Open-file rpt. 76-582, 114 p.

Grauch, R. I., 1978, Geology of the uranium prospect at Camp Smith, New York, with a new model for the formation of uranium deposits in metamorphosed submarine volcanogenic rocks; U. S. Geol. Survey Open-file Report 78-949, 29 p. Green, J. C., 1964, Stratigraphy and structure of the Boundary Mountain anticlinorium in the Erroll quadrangle, New Hampshire-Maine; Geol. Soc. Am. Special Paper 77, 78 p. 
Green, J. C. and Guidotti, C. V., 1968, The Boundary Mountains anticlinorium in northern New Hampshire and northwestern Maine; in Studies of Appalachian Geology: Northern and Maritime, ed. E-an Zen, W. S. White, J. B. Hadley and J. B. Thompson, Interscience, 255-266.

Greenberg, J. K., Hauck, S. A., Ragland, P. C., and Rogers, J. J. W., 1977, A tectonic atlas of uranium potential in crystalline rocks of the eastern U. S. ; U. S. Dept. of Energy, Grand Junction Office, Grand Junction, Colo.

Hall, B. A., 1970, Stratigraphy of the southern end of the Munsungun anticlinorium. Maine; Maine Geol. Survey Bull. 22, 63 p.

Harwood, D. S. and Berry, W. B. N., 1967, Fossiliferous Lower Paleozoic rocks in the Cupsuptic quadrangle, west-central Maine; U. S. Geol. Survey Prof. Paper 575-D; 16-23.

Hauseux, M. A., 1977, Mode of uranium occurrence in a migmatitic granite terrain, Baie Johan Beetz, Quebec; Can. Inst. Min. and Metall.., April, 110-116.

Howell, B. F., et al., 1944, Correlation of the Cambrian formations of North America; Geol. Soc. Am. Bull. , 55, 993-1003.

Hussey, A. M., II, 1968, Stratigraphy and structure of southwestern Maine: in Studies of Appalachian Geology; Northern and Maritime, ed. E-an Zen W. S. White, and J. B. Hadley, Interscience 291-301.

Jacob, R. E., 1974 a, The radioactive mineralization in part of the central Damara belt, South West Africa, and its possible origin; Atomic Energy Board, Ropublio of South $\Lambda$ frioa, PIN-231 (BR), $17 \mathrm{p}$.

Jacob, R. E., 1974 b, Geology and metamorphic petrology of part of the Damara orogen along the lower Swakop River, South West Africa; Chamber of Mines, Precambrian Research Unit, Bull. No. 17, Univ. of Cape Town, South Africa, $184 \mathrm{p}$.

Jenks, W. F., 1971, Tectonic transport of massive sulfide deposits in submarine volcanic and sedimentary host rocks; Econ. Geol., 66, 1215-1224. Jenkyns, H. C., 1980, Cretaceous anoxic events: from continents to oceans; J. Geol. Soc. London, 137, 171-188. 
Kalliokoski, J., Langford, F. F., and Ojakangas, R. W., 1978, Criteria for uranium occurrences in Saskatchewan and Australia as guides to favorability for similar deposits in the United States; U. S. Dept. of Energy, Report No. GJ BX-114 (78), 480 p.

Kemp, J. F., 1903 (1904), Graphite in the eastern Adirondacks, N. Y.; in Contributions to Economic Geology, U. S. Geol. Surv. Bull. 225, 512-514.

King, P. B. , 1976, Precambrian geology of the United States; an explanatory text to accompany the geologic map of the United States; U. S. Geol. Survey Prof. Paper 902, 85 p.

King, P. B. and Beikman, H. M., 1976, The Paleozoic and.Mesozoic rocks; a discussion to accompany the geologic map of the United States; U. S. Geol. Survey Prof. Paper 903, 76 p.

Larrabee, D. M. , Spencer, C. W. , and Swift, D. J. P., 1965, Bedrock geology of the Grand Lake area, Aroostook, Hancock. Penobscot, and Washingtnn rininties, Maine; U. S. Geol. Survey Bull. 1201-E, 1-38.

Leggett, J. K., 1980, British Lower Paleozoic black shales and their palaeooceanographic significance; J. Geol. Soc. London, 137, 139-156.

Lumbers, S. B., 1967, Geology and mineral deposits of the Bancroft-Madoc area; Geol. Assoc. Can., Guidebook, Aug. -Sept. 13-29.

Mackic, B., 1977, Petrogenesis of the Lac Sturgeon grantte and associated uranium oocurrenceg ncar Daie Johan Bcetz, Queluec; Geol. Soc. Am. symposium, Seattle, Wash., Nov. 7.

McCartney; W. D., 1969, Geology of Avalon Peninsula, southeast Newfoundland; in Atlantic Ocean--Geology and Continental Drift, Am. Assoc. Petr. Geol. Memoir 12, 115-129

McMillan, R. H., 1977, Metallogenesis of Canadian uranium deposits; a review; in Geology, Mining, and Extractlve Processing of Uranium; Inst. Min. and Metall., London, Jan. 43-55.

Moench, R. H., 1968, The Quimby and Greenvale Cove Formations in western Maine; U. S. Geol. Survey Bull. 1274-I, 1-17.

Mookherjee, A., 1976, Ores and metamorphism: temporal and genetic relationships; in Handbook of Strata-Bound and Stratiform Ore Deposits, ed. Wolf K. H. , Elsevier, N. Y., 4, 203-260. 
Neuman, R. B., 1967, Bedrock geology of the Shin Pond and Stacyville quadrangles, Penobscot County, Maine; U. S. Geol. Survey Prof. Paper 524-I, 1-37.

Nutt, C. J., 1980, Uranium potential of the Adirondack region; U. S. Geol. Survey, Open-file rpt. 80-1062, 19 p.

OECD Nuclear Energy Agency, 1977, Uranium resources, production and demand;

OECD Nucl. En. Agency and Int'l At. En. Agency, Paris, 136 p.

OECD Nuclear Energy Agency and International Atomic Energy Agency, 1980, World Uranium Geology and Resource Potential; Int'L Uranium Resource Evaluation Project; Miller Freeman Publications, Inc., San Francisco, 524 p. Osberg, P. H., 1968, Stratigraphy, structural geology, and metamorphism of the Waterville-Vassalboro area, Maine; Maine Geol. Survey Bull. No. 20, 64 p.

Palmẹ, A. R., 1980, Personal communication.

Pavlides, L., 1968, Stratigraphic and facies relationships of the Carys Mills Formation of Ordovician and Silurian age, northeast Maine; U. S. Geol. Survey Bull. $1264,1-44$.

Pavlides, L., Mencher, E., Naylor, R. S., and Boucot, A. J., 1964, Outline of the stratigraphic and tectonic features of northeastern Maine; U. S. Geol. Survey Prof. Paper 501-C, 28-38.

Robertson, D. S. and Lattanzi, C. R., 1974, Uranium deposits of Canada; Geosc. Canada, 1, 8-19.

Robinson, S. C. and Hewitt, D. F., 1958, Uranlum deposits of Bancroft region, Ontario; in Peaceful Uses of Atomic Energy, Proc. U. N. 2nd Int'l Conf., Geneva, vol. 2, 498-501:

Rodgers, J., 1968, The eastern edge of the North American continent during the Cambrian and Early Ordovician; in Studies of Appalachian Geology; Northern and Maritime, ed. E-an Zen, W. S. White, and J. B. Hadley, Interscience, 141-149.

Rowley, D. B., Kidd, W. S. F., and Delano, L. L., 1979, Detailed stratigraphic and structural features of the Giddings Brook Slice of the Taconic allochthon in the Grenville area; N. Y. St. Geol. Assoc. Guidebook 51, 186-242. 
Rutten, M. G., 1969, The geology of western Europe; Elsevier Publ. Co., N. Y. Ruzicka, V., 1977, Assessment of selected uranium occurrences and areas favourable for uranium mineralization in Canada; in Report of Activities, Part A, Geol. Surv. Can. Paper 77-1A, 27-29.

Ruzicka, V., 1979, Uranium and thorium in Canada, 1978; in Current Research, Part A, Geol. Surv. Can. Paper 79-1A, 139-155.

Sarcia, J. A., Carrat, H., Poughon, A. ; and Sanselme, H., 1958, Geology of uranium vein deposits of France; in Peaceful Uses of Atomic Energy, Proc. U. N. 2nd Int'l Conf., Geneva, vol. 2, 592-611.

Sheldon, R. P., 1980, Episodicity of phosphate deposition and deep ocean circulation--an hypothesis; Soc. Econ. Paleo, and Mineral., Sp. Publ. 29, Marine Phosphorites--a Symposium, 239-247.

Sheldon, R. P., 1981. Ancient marine phosphorites (in preparation). Stearn, C. W., Carroll, R. L., Clark, T. H., 1979, Geological evolution of North. America, 3rd ed., John Wiley and Sons, 566 p.

Stockwell, C. H. 1968, Geochronology of stratified rocks of the Canadian Shield; Can. Jour. Earth Sciences, 5, no. 3, 693-698.

Tan, Li-Ping, 1966, Major pegmatite deposits of New York State; N. Y. St. Mus. nd Sci. Serv. Bull. 408, 138 p.

Theokritoff, G., 1968, Cambrian hingeography and biostratigraphy of New England; in Studies of Appalachian Geology; Northern and Maritime, ed. E-an Zen, W. S. White, and J. B. Hadley, Inter science, 9-22.

Tjernvik, T. E., 1956, On the Early Ordovician of Sweden: stratigraphy and fauna; Bull. Upsala Untv. Geol. Inst., 36, 107-282.

U. S. Dept. of Energy, 1980, An assessment report on uranium in the United States of America; U. S. Dept. of Energy, Grand Junction Office, Grand Junction, Colo., GJO-111 (80)

Vine, J. D., Swanson, V. E., and Bell, K. G: , 1958, The role of humic acids in the geochemlstry of uranium; in Peaceful Uses of Atomic Energy, Proc. 2nd Int'l Conf., United Nations, 2, 187-191.

Wynne-Edwards, H. R., 1964, The Grenville Province and its tectonic significance; Proc. Geol. Assoc. Canada, 15, pt. 2, 53-67. 
Wynne-Edwards, H. R., 1969, Tectonic overprinting in the Grenville province, southwestern Quebec; Geol. Assoc. Canada, Special Paper 5, 163-182.

Zen, E-an, White, W. S., and Hadley, J. B., 1968, Studies of Appalachian geology: northern and maritime; Interscience. 
WORLD-CLASS URANIUM DEPOSITS

Quartz-pebble conglomerate:

Blind River, Canada; Witwatersrand, South Africa

Proterozoic unconformity-related:

N. Saskatchewan, Canada; N. Territory, Australia

Magmatic, pegmatitic, anatectic, migmatitic, metasomatic:

Pegmatitic--Bancroft, Canada

Alaskitic--Rossing, Namibia

Metasomatic (contact)--Mary Kathleen, Australia.

Alkalic syenitic--Ilimaussaq, Greenland; Pocos de Caldas, Brazil

Carbonatitic--Palabora, South Africa

Vein:

Beaver lodge, Sask., Canada; Massif Central, France

Proterozoic sandstone:

Oklo, Gabon

Miscellaneous type:

Reduzate sedimentary:

Black Shale--Ranstad, Sweden.

Volcanogenic-organic limestone--Pena Blanca, Mexico

Volcanogenic-shale--Kitts, Labrador, Canada

Tuff-organic shale--Lodeve, France

Granite-black shale contact--Nisa, Portugal; Esperanza, Spain

Volcanic--Pena Blanca, Mexico; Michelin, Labrador, Canada .

Calcrete--Yeelirrie, Australia; Namibia, South Africa

Phosphatic-karst--Bakouma, Central African Republic

Placer (modern)--Indus River, Pakistan 